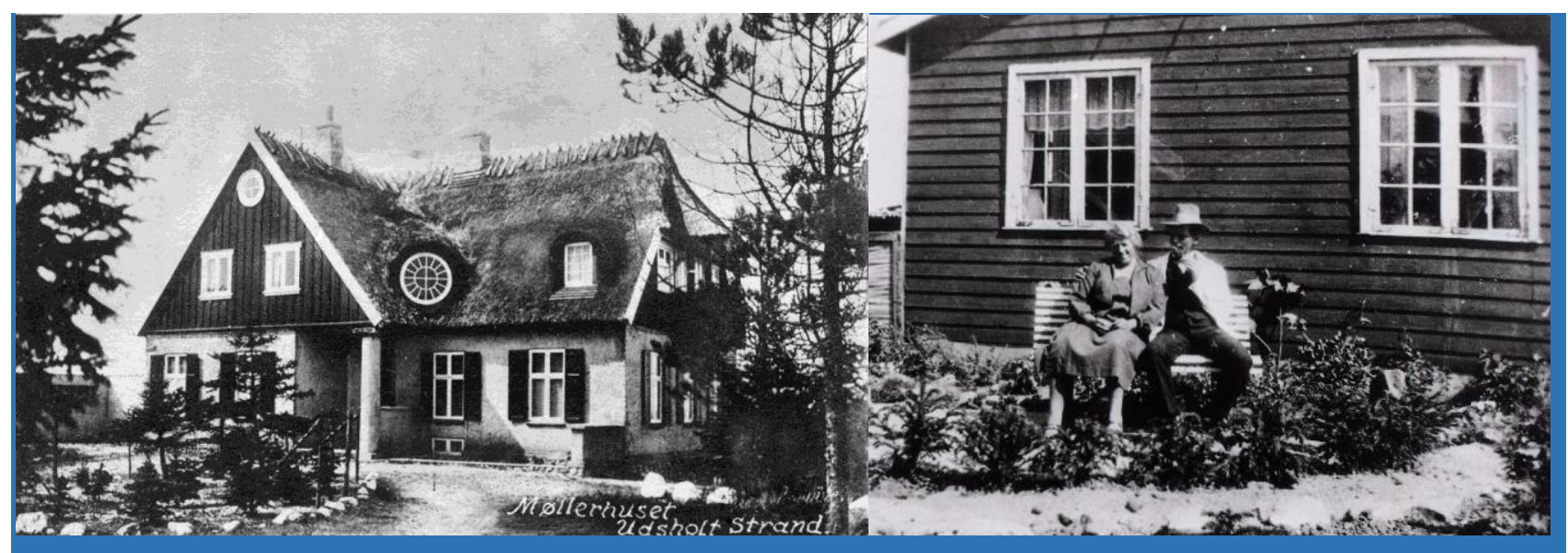

Henning Bro

\title{
Sommerhusbyen
}

Sommerhusbyer i mellem- og efterkrigstidens hovedstadsmetropol

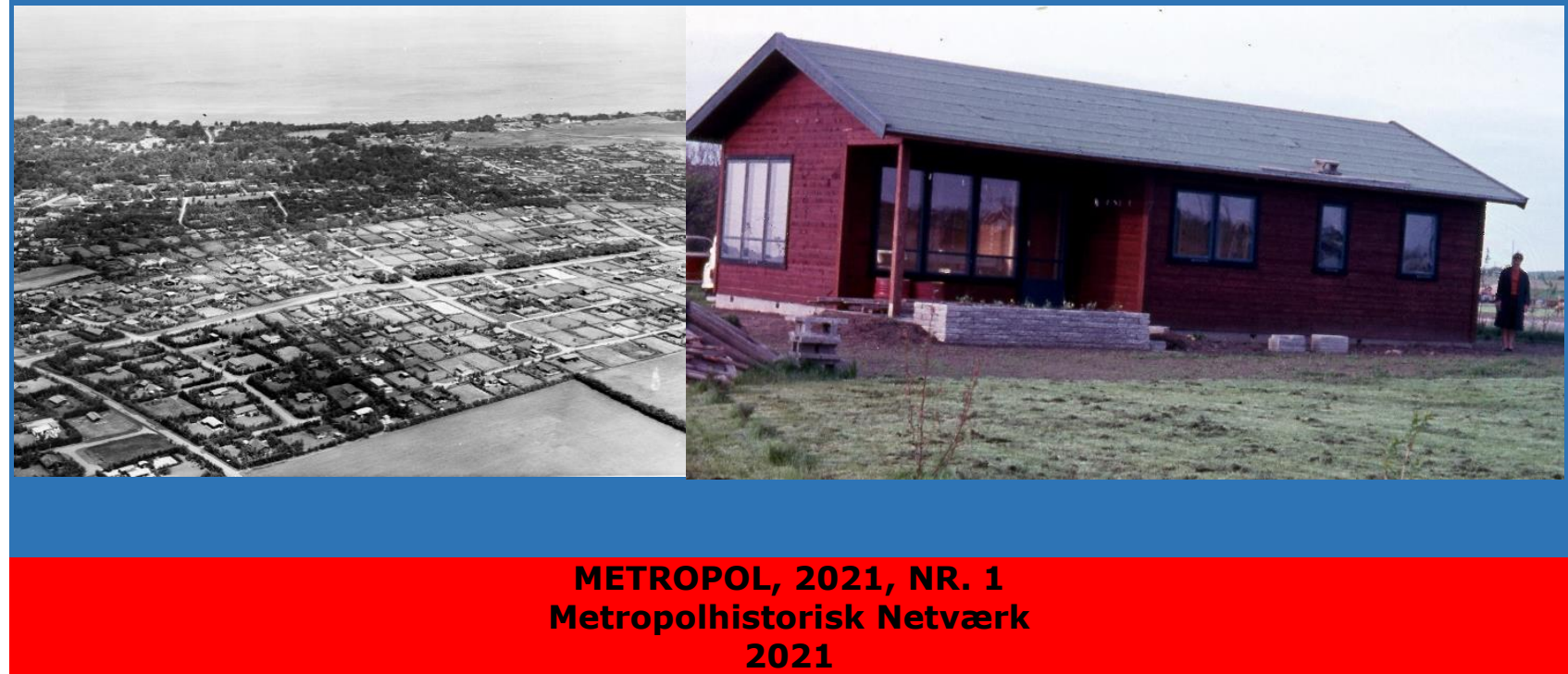




\section{DEL IV}

Planlagt sommerhusbyer: Sidste efterkrigstid 


\section{Kapitel 1}

\section{Sommerhusbølgen klinger af}

Mens den første efterkrigstid blev forbundet med centrale begreber som vækst, fuld beskæftigelse, levestandstandardsforøgelse og universalistisk velfærdstat, blev det for den sidste efterkrigstid: Økonomiske krise, arbejdsløshed, reallønsnedgang og snævrere rammer for velfærdsstaten. Samfundsmæssige forhold, der også stoppede den første efterkrigstids sommerhusboom.

\section{Tilbageslaget}

Blev 80,8 procent af efterkrigstidens samlede volumen på over 40.000 nye sommerhuse $i$ hovedstadsmetropolen, svarende til 1.427 sommerhuse pr. år, rejst i de første del af perioden mellem 1950 og 1973, opførtes de resterende 19,2 procent i dens sidste del. Med alene nye 7.800 nye sommerhuse eller 487 pr. år, betegnede den sidste efterkrigstid et massivt fald i tilvæksten af nye sommerhuse i metropolen (figur IV.1). Allerede i perioden 1970-1974 blev tilvæksten en del lavere end i 60 'erne for i de tre følgende femårsperioder at falde yderligere og i de to femårsperioder i 90 'erne at stagnere på omkring 3-4 procent.

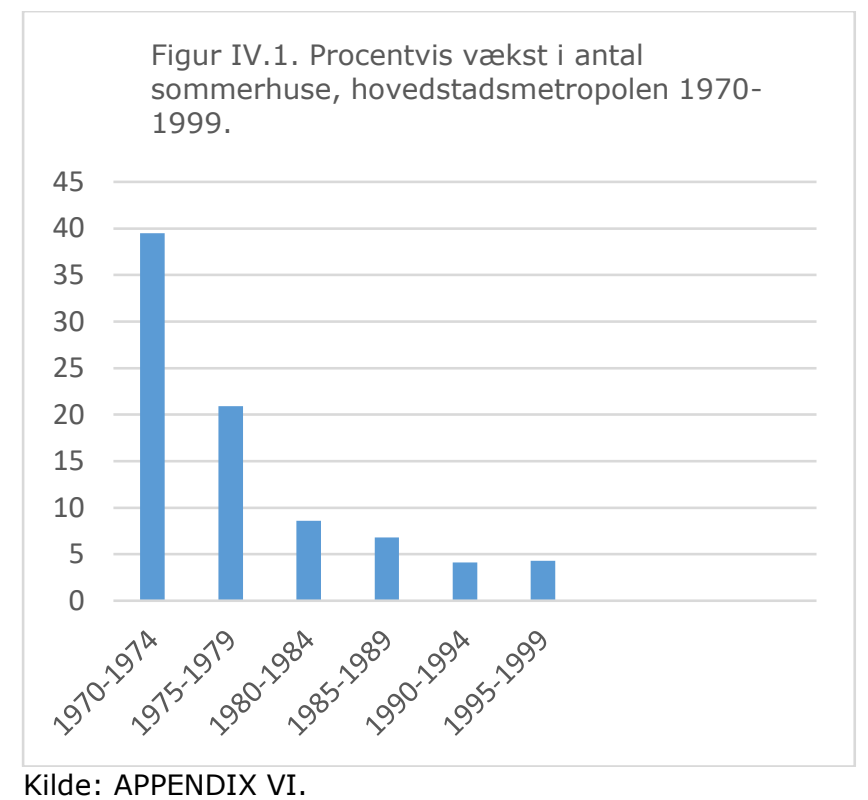

Et voldsom tilbageslag i tilvæksten af nye sommerhuse, men alligevel en forøgelse, der, som med dem der var blevet opført i den første efterkrigstid og inden århundredets midte og ikke var overgået til helårsbeboelse, i 1990 bragte hovedstadsmetropoplens sommerhusvolumen op på omkring 45.000. Det svarede til knapt en fjerdedel af Danmarks samlede antal sommerhuse, men indikerede i betragtning af at hovedstadsmetropolens folketal dette år udgjorde over en tredjedel af landets befolkning, at metropolens sommerhusbyer ikke havde været i stand til at opsuge det antal sommerhuse, som dens befolkning havde behov for $\mathrm{i}$ efterkrigstiden.

Forholdet mellem hovedstadsmetropolens vidtstrakte bymæssigt bebyggede områder og de tilbageværende arealer $\mathrm{i}$ dets åbne land, og det forhold at offentlige myndigheder særlig fra 60 'erne i stigende omgang forsøgte at inddæmme sommerhusbysspredningen, medvirkede således til, at der i efterkrigstiden opstod meget store sommerhusbyer uden for metropolens område. Særlig ved Odsherreds vestkyst ud til Sejerø Bugt, ved Store Bælt, Karrebæksminde og Marielyst ved Falsters østkyst opstod der i efterkrigstiden store sommerhusbyer, hvortil 
kom det store antal samtidige større og mellemstore sommerhusbyer på det øvrige Sjælland, uden for hovedstadsmetropolens område, Lolland, Falster og Møn. ${ }^{1}$

\section{Fndrede forudsætninger}

Med olieforsyningskrisen og den forstærkede økonomiske globalisering blev den sidste efterkrigstid og det meste af 90 'erne kendetegnet af tilbagevendende kriser. Den deraf følgende stigende arbejdsløshed og vigende realindkomst bragte hovedstadsmetropolen i stagnation, og fjernede også det økonomiske grundlag for det marginale varige forbrugsgode, som sommerhuset udgjorde.

\section{Hovedstadsmetropolens stagnation}

Havde hovedstadsmetropolen i den første efterkrigstid været kendetegnet af en massiv befolknings- og bymæssig tilvækst, reduceredes dens folketal op gennem den sidste efterkrigstid med 2 procent. Hovedstadsmetropolen fastholdt ganske vist et folketal på over 1,7 mio., men befolkningsudviklingen indikerede, at dens altdominerende rolle i det danske bysystem blev svækket i disse årtier.

Mens den bebyggelsesmæssige opfyldning af de indre forstæder i Københavns Amtskommune i perioden førte til samme fald i folketallet som i hovedstadsmetropolens som helhed, mistede hovedstaden således næsten 205.000 indbyggere. Et fald i dens befolkning på næsten 30 procent genereret af en i forhold til den første efterkrigstid voldsommere afvandring og det stigende fødselsunderskud, som fulgte af unge og yngres udflytning fra hovedstaden og den stadig større gruppe af ældre over 65, der blev tilbage. At hovedstadsmetropolens samlede folketal i den sidste efterkrigstid trods hovedstadens massive befolkningstilbagegang alene kom til udvise en svagt vigende tendens, var betinget af en samlet befolkningstilvækst på mere end en tredjedel i de ydre amtskommuner, hvor en væsentlig del af tidens nye bolig- og erhvervsbyggeri blev henlagt.
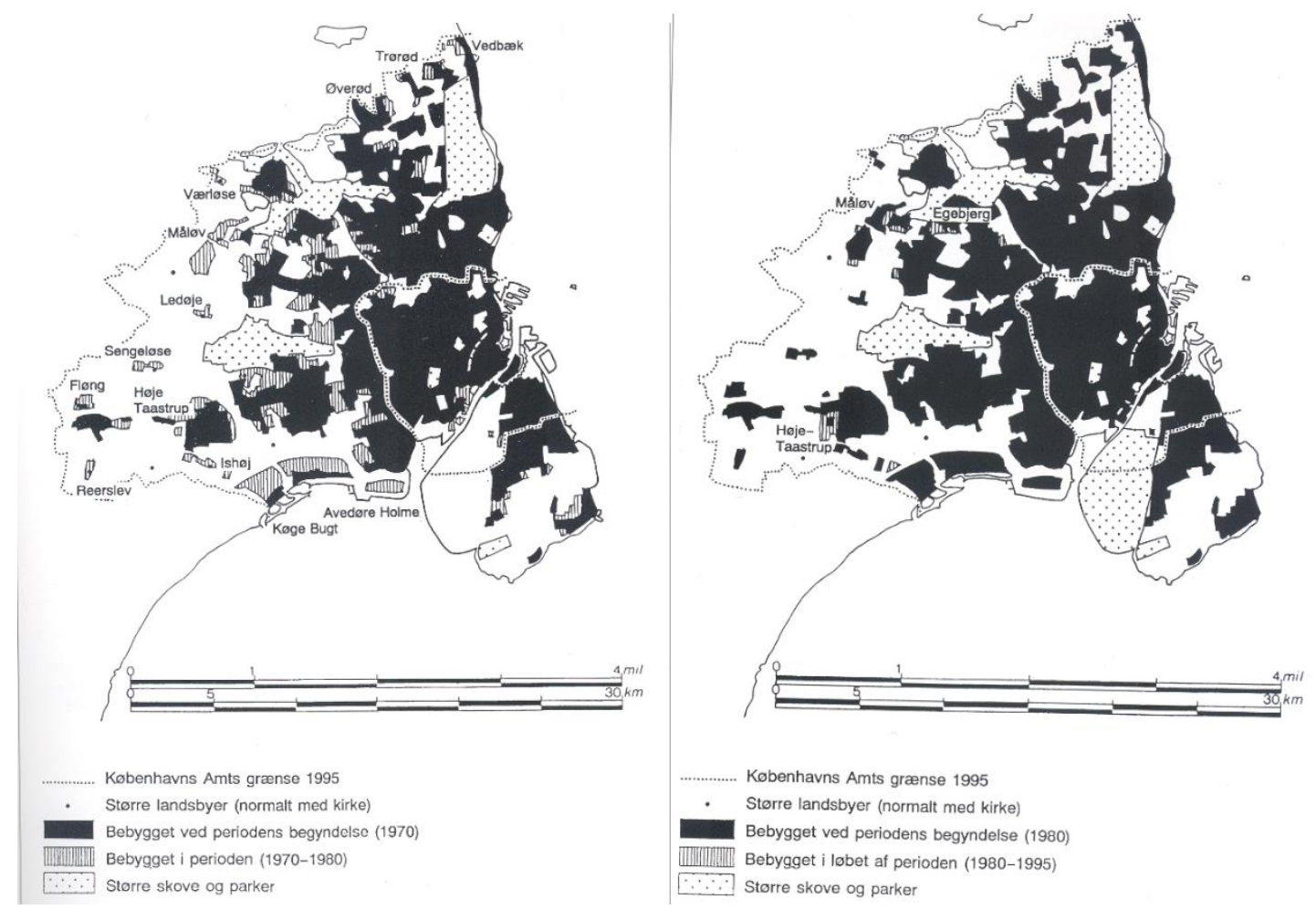

Bebyggelse i hovedstaden og Københavns Amtskommune 1970-1995. Til venstre: 1970-1980. Til højre: 1980-1990 (Kulturhistorisk oversigt, Københavns Amtskommune, 1999) 
Tabel IV.1. Årlig vækst i procent af Rådighedsbeløb og konsum i faste priser.

\begin{tabular}{|l|l|l|}
\hline & Rådighedsbeløb & Konsum \\
\hline $1970-1979$ & 2,3 & 1,8 \\
\hline $1980-1989$ & 0,9 & 0,8 \\
\hline
\end{tabular}

Kilde. $^{2}$

En dermed tiltagende urbaniseringsproces i hovedstadsmetropolens ydre dele, som trods stagnation og krise var med til at forstærke det urbane pres og dermed behovet for at søge ud af den stadig fortættede metropol med dens forsatte hektiske trafik, tiltagende miljøbelastninger og forcerede arbejdsliv. Et behov, der blev muligt at tilfredsstille med den sidste efterkrigstids yderligere udvidelse af den arbejdsfri tid. Fra 1985 blev den femte ferieuge således en realitet samtidig med, at den ugentlige arbejdstid i 1990 nåede ned på 37 timer. At det ikke i samme tiltagende omfang som i den første efterkrigstid blev et sommerhus, der gav mulighed for opnå et rekreativt ferie- og fritidsliv uden for hovedstadsmetropolen, blev betinget af de forandrede samfundsøkonomiske rammevilkår, som satte sig igennem i den sidste del af efterkrigstidsperioden. ${ }^{3}$

Tabel IV.2. Pris- og Iønudvikling, 1979-1989. Index: 1979=100

\begin{tabular}{|l|l|l|}
\hline & 1979 & 1989 \\
\hline Løn: Arbejdere & 100 & 183 \\
\hline Løn: Privatansatte funktionærer & 100 & 185 \\
\hline Forbrugerprigt ansætte funktionærer & 100 & 181 \\
\hline
\end{tabular}

Kilde. $^{4}$

\section{Økonomisk krise}

Ud over den stagnerede befolkningsmæssige udviklingstakt, der i den sidste efterkrigstid i hovedstadsmetropolen i sig selv lagede begrænsninger for den videre udbredelse af sommerhusbyer, fulgte virkningerne af tilbagevende økonomiske kriser i de første år af 70 'erne, gennem resten af årtiet og i 80 'erne med deraf følgende afvikling af traditionel arbejdsintensiv industri. En konsekvens af en svækket konkurrenceevne skabt af et højt produktionsomkostningsniveau og forstærket af priskonkurrence som følge af øget økonomisk globalisering med produktionsudflytninger til den tredje verden.

Kriserne manifesterede sig i en langt svagere økonomisk vækst end i den første efterkrigstid, år med negativ vækst og realindkomstnedgang og dermed tillige en svagere vækst i rådighedsbeløbet og det samlede konsum (tabel IV.1 og IV.2). Med den heraf følgende mindre vækst i det private forbrug forrykkedes forbrugssammensætningen på ny (tabel IV.3).

Tabel IV.3. Forbrugssammensætningen i procent, 1976-1987

\begin{tabular}{|l|l|l|}
\hline & 1976 & 1987 \\
\hline Fødevarer og nydelsesmidler & 24,3 & 20,2 \\
\hline Fodtøj og beklædning & 6,1 & 5,6 \\
\hline Husleje, prioriteter, vedligehold m.m. & 19,3 & 23,9 \\
\hline Brændsel, el, gas og varme & 5,2 & 6,8 \\
\hline Boligudstyr m.m. & 9,2 & 6,5 \\
\hline Medicin og lægeudgifter m.m. & 1,7 & 2,0 \\
\hline Transport og kommunikation & 16,7 & 16,1 \\
\hline Fritid, underholdning, undervisning m.m. & 9,7 & 8,5 \\
\hline Andet konsum & 7,8 & 10,4 \\
\hline Total & 100 & 100 \\
\hline
\end{tabular}

Kilde. ${ }^{5}$ Anm. Tabellen kan ikke umiddelbart sammenlignes med ovenstående tabeller over den historiske

forbrugssammensætning, da disse er udarbejdet ud fra andre kriterier for forbruget og fordeling på de forskellige forbrugsposter.

Selv om andelen af basale livsfornødenheder, fødevarer, beklædning m.m., forsat kom til at udgøre en mindre andel i det samlede forbrug, øgedes i nogle af de værste kriseår mellem 1976 og 1987 bolig- og opvarmningsudgifternes andel som følge af et stigende renteniveau og de kraftigt stigende oliepriser, der tillige var bidragende til tidens højere produktionsomkostninger. På nær andet konsum, førte det mindre økonomiske råderum og de 
højere bolig- og opvarmningsudgifter, til at de øvrige poster i forbrugssammensætning kom til at indgå med mindre andele i perioden. Markant for posten fritid m.m., hvorunder også sommerhus nu henregnedes, og i nogen grad transport, hvor tendensen til at køre mindre i privatbilen og levetidsforlænge den blev mere udtalt.

Tabel IV.4. Procentvis årlig tilvækst af antal sommerhuse, Danmark 1960-1990

\begin{tabular}{|c|c|c|}
\hline $60^{\prime}$ erne & $70^{\prime}$ erne & 80 'erne \\
\hline 6,6 & 4,5 & 0,7 \\
\hline Kilde Statistiks Årbog, 1968, s. 82,1970, s. 82,1973, s. 64, 1975, s. 72,1978, s. 54, 1981, s. 64 og 1990, s. 262.
\end{tabular}

At den sidste efterkrigstids kriser førte til, at forbrugerne i særlige grad nedprioriterede sommerhusbesiddelse som et varigt forbrugsgoder, kom til udtryk i en lagt lavere vækst i sommerhusbyggeriet end f.eks. i 60'erne (tabel IV.4) og i familiernes prioritering af erhvervelse af varige forbrugsgode.

Af familiernes besiddelse af varige forbrugsgoder i perioden 1974-1989 øgedes antallet af sommerhuse alene med 8 procent, hvorved forsat kun ni procent af de danske familier rådede over et sådant gode (tabel IV.5). Til gengæld prioriteredes besiddelsen af en ejerbolig, bil og elementært udstyr til helårsbogen, køleskab, vaskemaskine, tv, telefon, højere og højest mere avancerede hårde hvidevarer, opvaskemaskine og dybfryser, og tidens nye produkter til hjemmet: Video og senere hjemmecomputer. I krisens lys prioriteredes helårsboligen og varige forbrugsgoder i denne således højere end en sekundær fritids- og feriebolig. Et tydeligt bevis på, at sommerhusbesiddelse var et yderst marginalt forbrugsgode, der var afhængig ikke bare af den enkeltes husstandsindkomstniveau, men også af konjunkturforløbet. ${ }^{6}$

Tabel IV.5. Antal familier og antal familier i besiddelse af varige forbrugsgoder

\begin{tabular}{|c|c|c|c|c|}
\hline & \multicolumn{2}{|c|}{ Tilvækst. Index:1979=100 } & \multicolumn{2}{|c|}{ Procentandel } \\
\hline & $1974^{1}$ & 1989 & \multirow[t]{3}{*}{$1974^{1}$} & \multirow[t]{3}{*}{1989} \\
\hline \multicolumn{3}{|c|}{ Antal familie } & & \\
\hline & 100 & 111 & & \\
\hline \multicolumn{5}{|c|}{ Antal familier med varige forbrugsgoder } \\
\hline Ejerbolig & 100 & 128 & 48 & 55 \\
\hline Sommerhus & 100 & 108 & 9 & 9 \\
\hline Personbil & 100 & 128 & 52 & 60 \\
\hline Vaskemaskine & 100 & 158 & 46 & 66 \\
\hline Opvaskemaskine & 100 & 284 & 9 & 23 \\
\hline Fjernsyn & 100 & 119 & 86 & 92 \\
\hline Video & $100^{2}$ & 379 & $8^{4}$ & 30 \\
\hline Telefon & 100 & 168 & 61 & 93 \\
\hline Køleskab & 100 & 138 & 78 & 97 \\
\hline Dybfryser & 100 & 208 & 45 & 85 \\
\hline Hjemmecomputer & $100^{3}$ & 140 & $8^{5}$ & 12 \\
\hline
\end{tabular}

Kilde. $^{7}$ Anm. 1: Se efterfølgende tabelnoter. 2: Basisår: 1982. 3: Basisår: 1987. 4: 1982. 5: 1987. 


\section{Sommerhusbyernes stagnationsperiode}

Ligesom for hele hovedstadsmetropolen repræsenterede den sidste efterkrigstid tillige en stagnationsperiode for dens sommerhusbyer, men førte også til en række ikke uvæsentlige forandringer i disses sociale sammensætning og sommerhuses karakter.

\section{Fordeling}

Udover to nye førte den sidste efterkrigstidstids lav tilvækst i sommerhusbyggeriet ikke til dannelse af yderligere sommerhusbyer i hovedstadsmetropolens åbne land. I spekulativ forventning om en lang periode med vedvarende tilvækst i sommerhusbyggeriet var der i Kattegatkystens sommerhusbybælte tidligt i den første efterkrigstid, og inden offentlige myndigheder i videre omfang ved den stedlige delregionale fredningsplan og konkrete fredninger fra 60' erne her inddæmmede sommerhusbysspredningen, udstykket så rigelige arealer, at de kunne opsuge en betydelig del af den sidste efterkrigstids sommerhusbyggeri. Mens kystens sommerhusbyer tegnede sig for 54 procent af den første efterkrigstids nye sommerhuse, blev de i den sidste efterkrigstidsperiode i stand til at opsuge tæet ved 60 procent dennes sommerhusbyggeri.

Da myndighedernes planindgreb overfor sommerhusbysspredningen, belært af de historiske erfaringer fra Kattegatkysten, havde været mere udtalte i andre af dele af hovedstadsmetropolens åbne land, kom sommerhusbyerne i Hornsherred i forhold til den første efterkrigstid kun til at opsuge en lidt større del af den sidste efterkrigstids nye sommerhuse. I de tidligt bebyggede øvrige sommerhusbyer og dem ved Roskilde Fjords nordog østside blev den sidste efterkrigstids andel af nye sommerhuse endda marknat mindre i forhold til den første efterkrigstidsperioden.

Med de vide udstykningsplaner, der i den første efterkrigstid lå til grund for sommerhusbydannelserne og de byggemodningsdispositioner, der $\mathrm{i}$ den forbindelse eller efterfølgende blev truffet, var rammene allerede sat for det begrænsede antal nye sommerhuse, der kom til i de sidste efterkrigstid. Dog således, at den relativt begrænsede offentlige kloakering under indtryk af periodens øgede regional- og lokalkommunale miljøbestemmelser forøgedes en smule i den sidste efterkrigstid. ${ }^{8}$

\section{Øget ulighed}

Udbyggedes hovedstadsmetropolens sommerhusbyer i den sidste efterkrigstid sig inden for allerede givne rammer, undergik de med periodens ændrede forudsætninger for sommerhusbyggeriet en række forandringer til trods for, at den sidste efterkrigstids sommerhuse kun udgjorde en mindre del af metropolens samlede sommerhusvolumen. Mens den sociale sammensætning af førstegangssommerhusejere i den første efterkrigstid udjævnedes en smule, blev den i sommerhusbyggeriet i den sidste del af efterkrigstidsperioden på ny præget af større ulighed (tabel IV.6). Efter at andelen af førstegangssommerhusejende arbejdere i den første efterkrigstid var steget, på trods af at arbejderklassens andel af erhvervsbeskæftigede i hovedstadsmetropolen faldt, reduceredes arbejderklasens andel af denne ejergruppe i den sidste efterkrigstids nye sommerhuse parallelt med klassens mindre andel af erhvervsbeskæftigende for at lægge sig på samme lave niveau som i perioden før midten af århundredet.

Selv om andelen af førstegangsejende øvrige funktionærer på samme tid øgendes med ti procent, faldt de mindre selvstændiges andel af samme ejergruppe så meget, at andelen af de to mellemindkomstslag i ejergruppen kun forøgedes med fem procentpoint. Samlet reduceredes andelen af førstegangsejere af nye sommerhuse for de lavere og mellemste indkomstlag af arbejdere, øvrige funktionærer og mindre selvstændige i den sidste 
efterkrigstids sommerhusbyer i hovedstademetropolen således med to procent, mens andelen af førstegangssommerhusejerne fra de høje indkomstlaget af større selvstændige og højere funktionærer forøgedes med denne procentsats.

Tabel IV.6. Procentvis social sammensætning af førstegangsejere af nye sommerhuse i hovedstadsmetropolen, 19741990, og af erhvervsbeskæftigede i hovedstadsmetropolen, 1970 og 1990.

\begin{tabular}{|c|c|c|c|c|c|c|}
\hline \multirow[t]{3}{*}{ Stilling } & \multirow{3}{*}{\multicolumn{2}{|c|}{$\begin{array}{l}\text { Sommerhusejere, } \\
1974-1990\end{array}$}} & \multicolumn{4}{|c|}{$\begin{array}{l}\text { Hovedstadsmetropolens erhvervsbeskæftigede } \\
\text { Befolkning }\end{array}$} \\
\hline & & & \multicolumn{2}{|l|}{1970} & \multicolumn{2}{|l|}{1990} \\
\hline & & & Hovedstaden & Forstæder & Hovedstaden & Forstæder \\
\hline Større selvstændige & 7,4 & & & & & \\
\hline Mindre selvstændige & 11,7 & & & & & \\
\hline Selvstændige, total & & 19,1 & 7,1 & 9,5 & 8,1 & 7,7 \\
\hline Ledende funktionærer & 10,3 & & & & & \\
\hline Akademisk uddannede funktionærer & 7,6 & & & & & \\
\hline Højere funktionærer, i alt & 17,9 & & & & & \\
\hline Øvrige funktionærer & 51,9 & & & & & \\
\hline Funktionærer, total & & 69,8 & 42,6 & 44,6 & 59,4 & 63,8 \\
\hline Faglærte arbejdere & 10,6 & & & & & \\
\hline Ufaglærte arbejdere & 0,5 & & & & & \\
\hline Arbejdere, total & & 11,1 & 50,0 & 44,1 & 32,5 & 28,5 \\
\hline Total & 100 & 100 & 100 & 100 & 100 & 100 \\
\hline
\end{tabular}

Kilde: Henvisninger under Appendix VI. Bro: Hovedstadsmetropolen- den danske byregion, 2020, s. 1237-1238.

En særegen social sammensætning førstegangssommerhusejerne, der også i den sidste efterkrigstid satte sig igennem i forhold til disses bopæl og overordnede boligforhold (tabel IV.7). Skønt ejerggruppens bopælsmønster blev mere jævnt fordelt end i de forudgående perioder, og i høje grad nærmede sig befolkningens samlede regionale fordeling $\mathrm{i}$ hovedstadsmetropolen, havde en relativt større andel af førstegangsommerhusejere bopæl i velhaverforstæderne på Nordegnen og de mere velstillede forstæder på Nordvestegnen end $\mathrm{i}$ Vestegnsforstæderne og nu også hovedstaden. Andelen med bopæl uden for de centrale forstadsegne forøgedes i peiroden en smule, men lå som tidligere og på samme baggrund langt under metropolbefolkningens fordeling på disse dele af hovedstadsmetropolen.

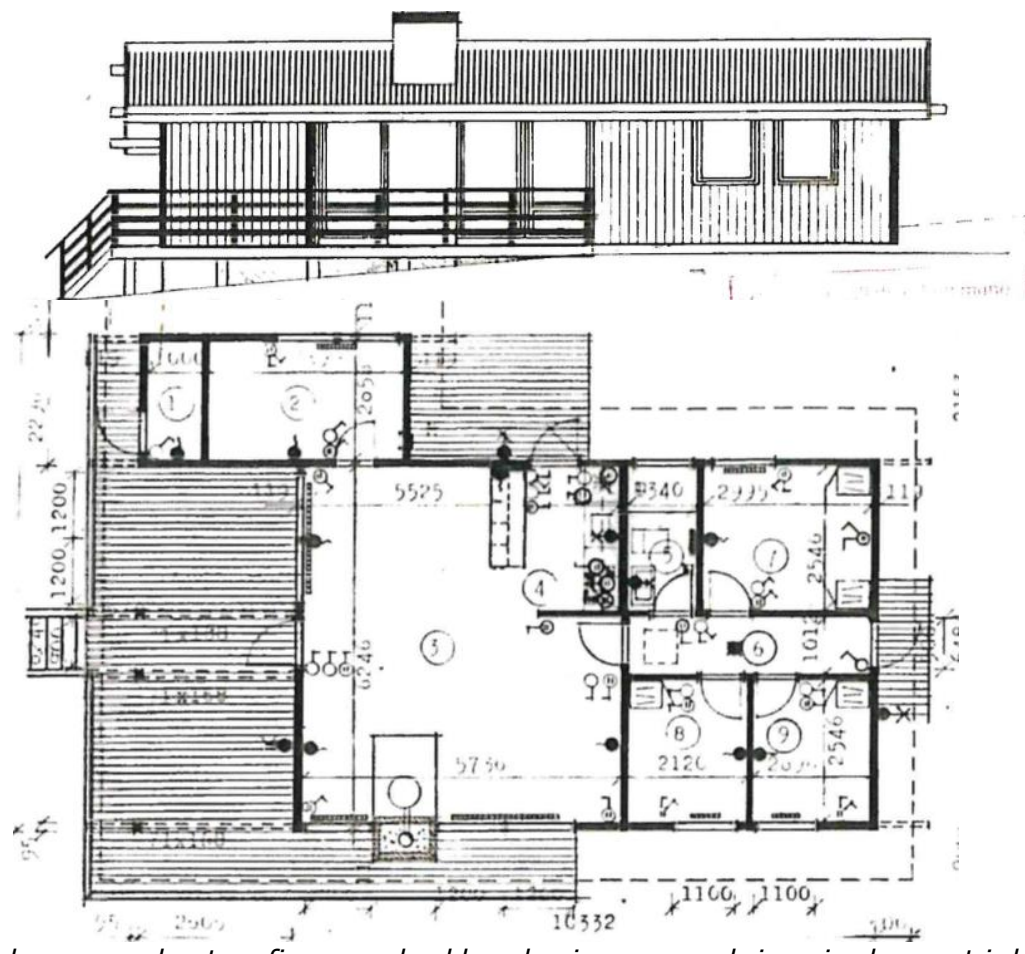

Skarridsø Huse var et af de sommerhustypefirmaer, der klarede sig gennem krisen i erhvervet i den sidste efterkrigstid. Firmaet slog dog ind på produktion af større sommerhuse som dette fra sommerhusbyen Udsholt Strand fra 1979. (Gribskov Kommune, digitale byggesager, https://www.weblager.dk/) 


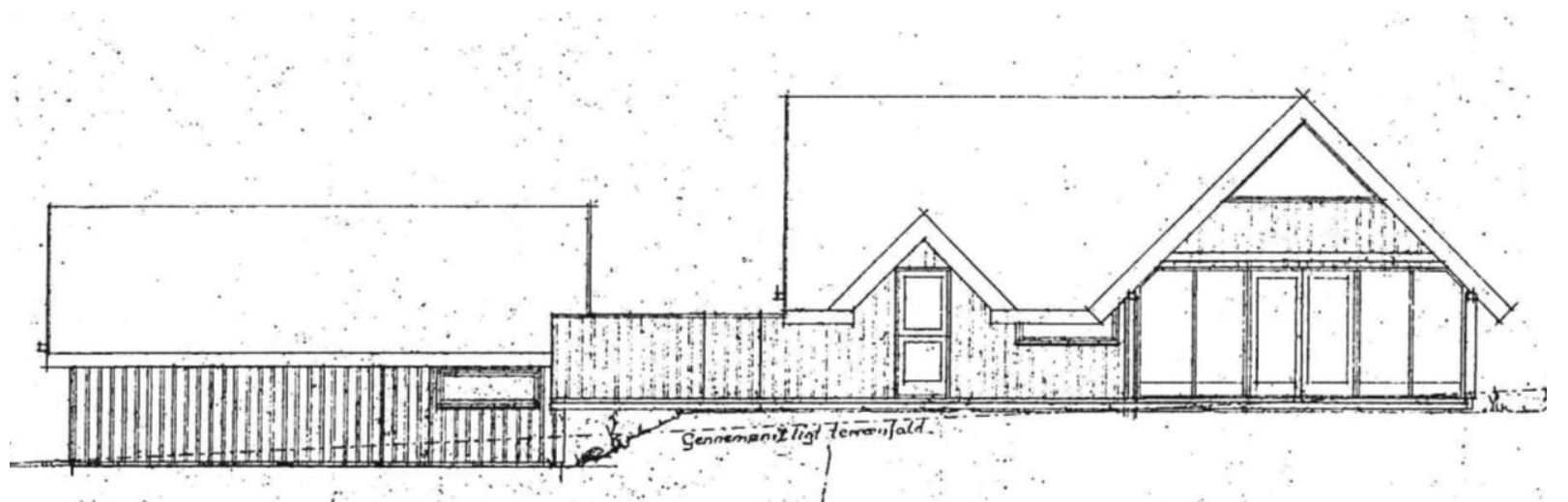

Kattegatkysten sommerhusbybælte blev også i den sidste efterkrigstid det sted, hvor man kunne se de største og arkitekttegnede nyopførte sommerhus. Her et fra sommerhusbyen Tisvilde fra 1977. (Gribskov Kommune, digitale byggesager, https://www.weblager.dk/)

Med det om end mere beherskede nybyggeri af enfamiliehuse, der kendetegnede den sidste efterkrigstid, og de samtidige meget omfattende saneringer, byfornyelser og sammenlægninger af lejligheder, blev forholdet mellem boliger i etagebebyggelser og enfamiliehuse forskudt markant. Ikke desto mindre syntes førstegangsejere af periodens nye sommerhuse i hovedstadsmetropolen fortsat i overvejende grad at have beboet et enfamiliehus.

Tabel IV.7. Procentvis fordeling af bopælsområde og boligform for førstegangejere af nye sommerhuse, 1974-1990, og i hovedstadsmetropolen, 1970 og 1990.

\begin{tabular}{|l|l|l|l|}
\hline & Sommerhusejere & Hele hovedstadsmetropolens befolkning \\
\hline Bopæl i: & $1950-1973$ & 1970 & 1990 \\
\hline Hovedstaden & 32,0 & 41,8 & 32,2 \\
\hline Nordegnen & 22,5 & 13,5 & 13,4 \\
\hline Nordvestegnen & 19,9 & 8,5 & 7,8 \\
\hline Vestegnen & 17,6 & 15,4 & 17,9 \\
\hline Andet & 8,0 & 20,8 & 28,7 \\
\hline Total & 100 & 100 & 100 \\
\hline Etagebolig & 42,9 & 68,2 & 37,5 \\
\hline Enfamiliehuse & 57,1 & 31,8 & 62,5 \\
\hline Total & 100 & 100 & 100 \\
\hline
\end{tabular}

Kilde: Henvisninger under Appendix VII. https://www.kk.dk/sites/default/files/migrated/sc/1972-

aarbog.pdfhttps://www.dst.dk/Site/Dst/Udgivelser/GetPubFile.aspx?id=20944\&sid=befkom 1990

https://www.kk.dk/sites/default/files/migrated/sc/1992-aarbog.pdf

Mens arbejdere og offentligt ansatte funktionærer i de værste kriseår mellem 1979 og 1989 opnåede en svargere reallønsudvikling end privatansatte funktionærer, hindrede den sidste efterkrigstids kriser samtidig, at sidstnævnte gruppe og større virksomhedsejere kunne opnå de langt større indkomstgevinster, som havde været muligt i den første efterkrigstid.

Virkningerne af velfærdsstatens socialt sikrende og omfordelende velfærdssystem slog således kraftigere igennem, hvilket bevirkede, at den maksimale udjævningsprocent reduceredes med 1,6 procentpoints i perioden $1976-1986$, og at de to to-tiendedele med de laveste indkomster i samme periode opnåede en stigning $i$ andelen af den samlede indkomst fra 6,8 og 13,8 procent til 7,4 og 14,3 procent (tabel IV.8).

Den sidste efterkrigstids jævnere indkomstudvikling blev dog, som påvist, ikke stor nok til at ændre den sociale sammensætning af førstegangsejere af nye sommerhuse i hovedstadsmetropolens sommerhusbyer. Tværtimod. Den samlede indkomstudjævning var så besked, at den laveste indkomstgruppe, omfattende 40 procent af skatteyderne og godt 20 procent af den samlede indkomst, forsat ikke kunne rykke op i gruppen af sommerhusejere. Til denne gruppe kunne de tre tiendedele med de højeste indkomster til gengæld fortsat henregnes, da de, endskønt et fald i den samlede andel af den samlede indkomst fra 49,8 og 47,9 , stadig rådede over næsten halvdelen af denne, og dermed forsat havde mulighed for at 
udvide det samlede forbrug til at omfattede det yderst marginale varige forbrugsgode, som et nyt sommerhus udgjorde. En mulighed, som de mellemliggende tre tidendedele i indkomstskalaen havde $i$ et vist omfang. For denne indkomstgruppe $\varnothing$ gedes andelen af den samlede indkomst i perioden ganske vist kun fra 29,7 til 30,5 procent, men måske nok til at en større del af denne kunne rykke op som ejere af det mindre antal sommerhus, der opførtes i den sidste efterkrigstid. ${ }^{9}$

Tabel IV.8. Skattepligtig procentvise indkomstfordeling på tiendedele efter stigende skattepligtig indkomst, $1976-1986$

\begin{tabular}{|l|l|l|}
\hline Tiendedele & 1976 & 1986 \\
\hline 1. & 2,3 & 2,6 \\
\hline 2. & 4,5 & 4,8 \\
\hline 3. & 6,3 & 6,4 \\
\hline 4. & 7,5 & 7,9 \\
\hline 5. & 8,7 & 9,1 \\
\hline 6. & 9,9 & 10,2 \\
\hline 7. & 11,1 & 11,2 \\
\hline 8. & 12,5 & 12,5 \\
\hline 9. & 14,5 & 14,3 \\
\hline 10. & 22,8 & 21,1 \\
\hline Total & 100 & 100 \\
\hline Udjævningsprocent & 20,9 & 19,3 \\
\hline
\end{tabular}

Kilde. ${ }^{10}$. Anm. Udjævningsprocent: Den maksimale udjævningsprocent

\section{Standardforbedringer}

En anden marknat forandring, der kendetegnede den sidste efterkrigstids sommerhusbyer i hovedstadsmetropolen, blev den standard periodens nye sommerhuse fik, og den endnu mere fremtrædende rolle, som typesommerhuset opnåede blandt disse.

\section{Et signifikant løft}

Med en kombination af den noget større andel af førstegangssommerhusejerne, som de højere indkomstlag opnåede i de sidste efterkrigstid, og den forsatte teknologiudvikling, der kendetegnede bygge- og anlægssektoren, opnåede periodens sommerhusbyggeri et så signifikant løft, at det på alle parametre for sommerhusstandard hævede sig markant i forhold den første efterkrigstids sommerhuse, og efterhånden nåede op på næsten samme niveau som enfamiliehuset (tabel IV.9).

Tabel IV.9. Parametre for standarden i nye sommerhuse, hovedstadsmetropolen, 1974-1990.

\begin{tabular}{|c|c|c|c|c|c|}
\hline \multirow[t]{2}{*}{ Opført, i procent: } & Som selvbyg & Af bygmester & Med arkitektbistand & Af byggefirma & Total \\
\hline & 4,3 & 14,1 & 12,8 & 68,8 & 100 \\
\hline \multicolumn{6}{|c|}{ Rumfordeling, i procent: } \\
\hline \multirow[t]{2}{*}{1 rum } & 2 rum & 3 rum & 4 rum & 5 el. fl. Rum & Total \\
\hline & 7,5 & 51,5 & 29,7 & 11,3 & 100 \\
\hline \multirow[t]{2}{*}{ Toilet, i procent: } & Udenfor huset & I huset & Total & \multirow{2}{*}{\multicolumn{2}{|c|}{$\begin{array}{l}86,2 \text { procent med bad. } \\
\text { Alle med køkken }\end{array}$}} \\
\hline & 1,8 & 98,2 & 100 & & \\
\hline Areal: & \multicolumn{5}{|c|}{ Mellem 31-162 $\mathrm{m}^{2}$.I gennemsnit $70,1 \mathrm{~m}^{2} \cdot 95,5$ procent fuldisolerede } \\
\hline \multicolumn{3}{|c|}{ Opført, procentfordeling: } & \multicolumn{3}{|c|}{ Forsynet, procentfordeling: } \\
\hline Af træ & Som grundmuret & Total & Med skorsten & Uden skorsten & Total \\
\hline 91,6 & 8,4 & 100 & 69,3 & 30,7 & 100 \\
\hline \multicolumn{2}{|c|}{ Opført på, procentfordeling: } & \multicolumn{2}{|c|}{ Vandforsyning, procentfordeling: } & \multicolumn{2}{|c|}{ Spildevandsafledning, procentfordeling: } \\
\hline Piller & Fundament & Udenfor hus & I hus & Ingen & Sivebrønd m.m. \\
\hline 0,8 & 99,2 & 0,0 & 100 & 0,0 & 100 \\
\hline
\end{tabular}

Kilde: Henvisninger under Appendix VI.

Den sidste efterkrigstids sommerhus i hovedstadsmetropolens sommerhusbyer blev således i gennemsnit $20 \mathrm{~m}^{2}$ større, rummede en større andel med fire eller flere værelser, fuldisoleredes i 96 procent af tilfældene, og udrustes i et større omfang med en skorsten; muret eller et aftræksrør af metal. En forsvindende del opførtes på piller og var ikke udrustet med toilet, mens 86 procent havde badefaciliteter. Alle havde indlagt vand og var tilsluttet spildevandsafledning i form af sivebrønd, septiktank eller offentlig kloak. At en større del 
opførtes i træ, var ikke udtryk for en ringere kvalitet, men en reaktion mod den første efterkrigstids ganske udbredte gasbetonsommerhuse, der ofte ikke blot var uskønne, men ikke havde sommerhusets karakter. ${ }^{11}$
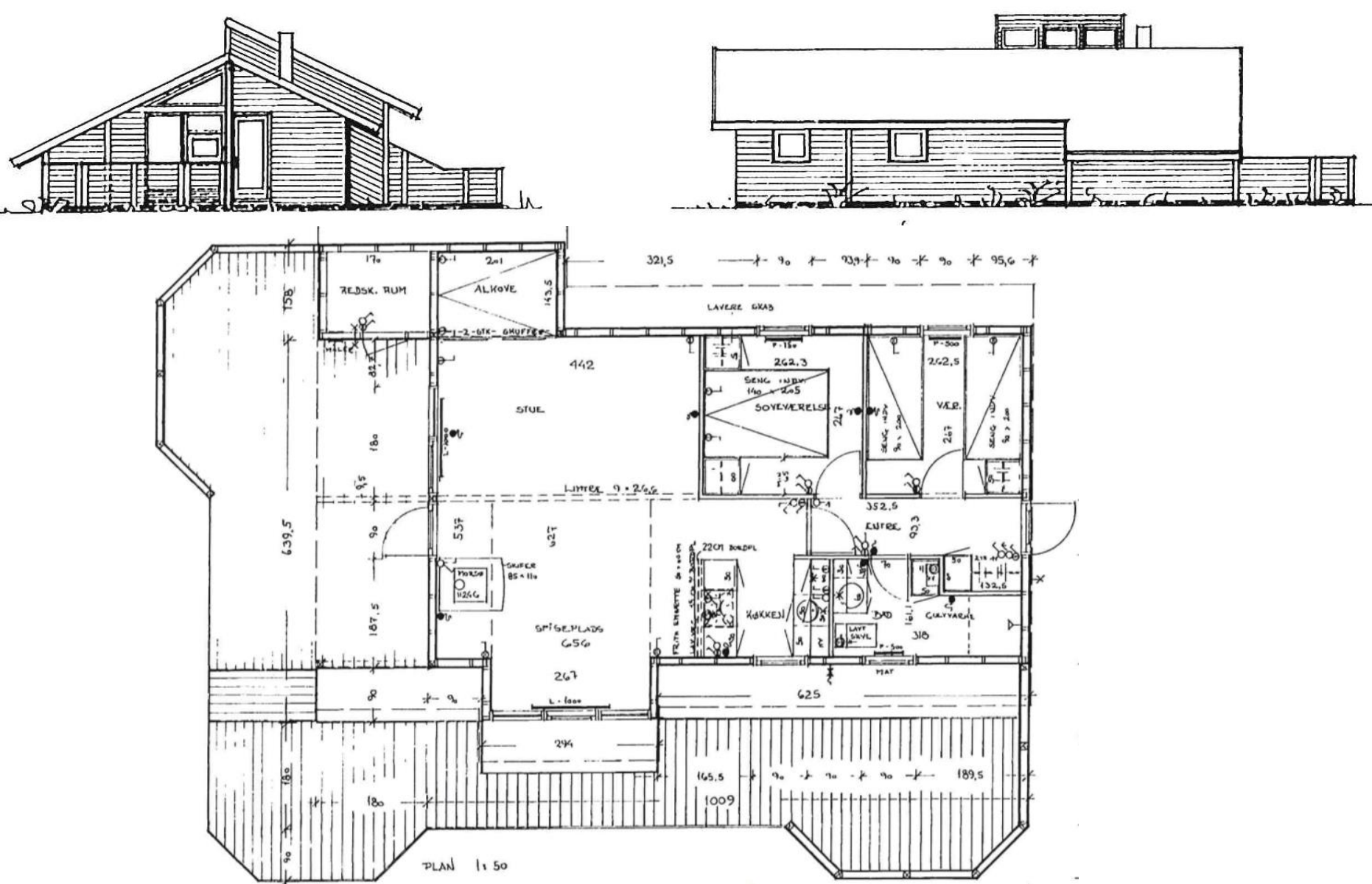

Firmaet bag Møllebæk Huse havde rødder tilbage til den første efterkrigstid, men slog sig i den sidste del af perioden op på store og velindrettede sommerhuse, som dette $i$ sommerhusbyen Asserbo fra 1988 (Gribskov Kommune, digitale byggesager, https://www.weblager.dk/)

\section{Typesommerhusets dominans}

En markant forskel mellem den første og sidste efterkrigstids sommerhuse i hovedstadsmetropolens sommerhusbyer blev tillige sammensætningen af de aktører, der stod bag periodens sommerhusbyggeri; jf. APPENXIX VIII. For det store antal typesommerhusproducenter- og importører, der var opstået med den første efterkrigstids sommerhusboom, førte den sidste periodes langt mindre nybyggeri af sommerhus til en alvorlig krise. Hertil føjede sig, at den større ulighed i sammensætningen af førstegangsejere ændrede sommerhusefterspørgslen i retning af større, mere veludrustede og dermed også dyrere typesommerhuse.

Eneste formildende omstændighed i forhold til disse ændrede konjunkturelle og strukturelle vilkår for typesommerhusbranchen blev, at selvbyggeri blev mindre udbredt, og at de små og mellemstore håndværksmester blev de helt store tabere i byggeriet af den sidste efterkrigstids nye sommerhuse $\mathrm{i}$ hovedstadsmetropolens sommerhusbyer. Mens håndværksmestrenes andel heraf i den første eftertidskrigstid udgjorde en fjerdedel, reduceredes den i den sidste periode til en syvendedel. Da de arkitektegnedes andel af den sidste efterkrigstids sommerhusbyggeri kun forøgedes minimalt, blev der således plads til, at typesommerhuset kunne øge sin andel fra 55 procent i den første efterkrigstid til 69 procent i den sidste del af periode. 


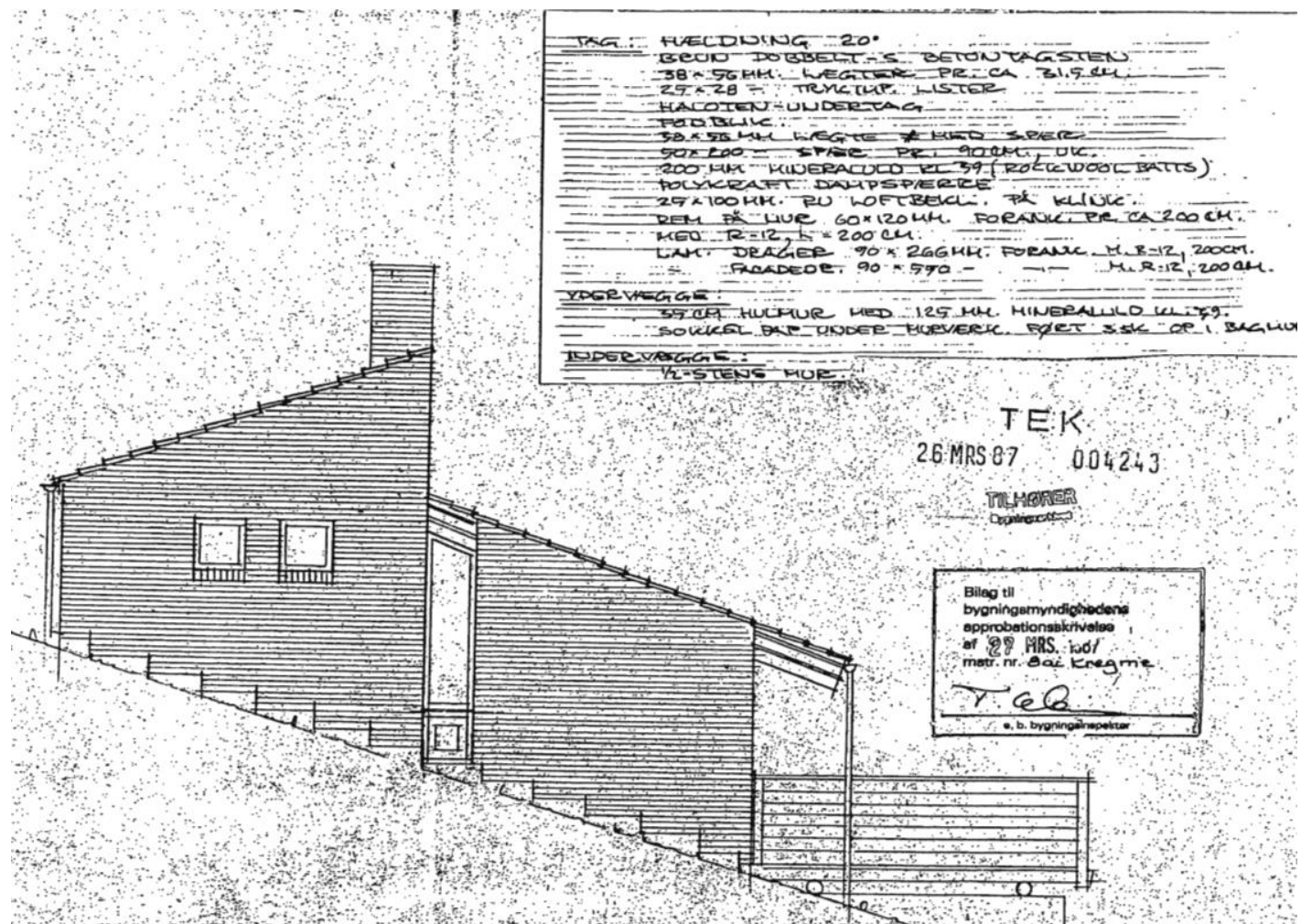

Arkitekttegnet grundmuret luksussommerhus fra 1987 beliggende lige ned til Roskilde Fjord i sommerhusbyen Lille Kregme (Halsnæs Kommune, digitale byggesager, https://www.weblager.dk/).

I dette relativt større, men forandrede og i volumen langt mindre marked gav dettes usynlige hånd særdeles gode betingelser for de velbyggede, populære, i udtryksform særegne og forholdsvis dyre typesommerhuse fra Kalmar Husene, der ikke i den første efterkrigstid kom med i rækken af de mest udbredte typesommerhuse i hovedstadsmetropolens sosommerhusbyer (tabel IV.10). Med 14 procent af samtlige ny typesommerhuse blev Kalmar Husene til gengæld de mest udbredte i den sidste efterkrigstid.

Efterfulgt af også i den første efterkrigstid stærkt forekommende og stadig relativt dyre sommerhuse fra Västkust Stugan og Skarridsø Huse, der med knapt 10 og 9 procent tegnede sig for de anden- og tredje mest udbredte nye typesommerhuse. Mens det store og velkonsoliderede svenske firma, der stod bag Västkust Stugan, styrkede sin position som leverandør af typesommerhuse til hovedstadsmetropolens sommerhusbyer, klarede Skarrids $\varnothing$ Husene efter en betalingsstansning i 1974 sig alene ved at blive drevet videre af medarbejderne i en årrække, indtil MSH Huse i 1980 overtog produktionen, og senere tillige påtog sig fremstillingen af de huse, Jeppesens Savværk havde stået bag.

Tabel IV.10. Procentvis fordeling af ti største producenter af typesommerhuse til hovedstadsmetropolens sommerhusbyer, 1974-1990

\begin{tabular}{|l|l|}
\hline Kalmar Husene & 13,9 \\
\hline Västkust Stugan & 9,6 \\
\hline Skarridsø Huse & 8,9 \\
\hline Friness Huset & 7,5 \\
\hline Myresjö Huse & 5,6 \\
\hline Høm Huse & 4,8 \\
\hline EBK Huse* & 4,6 \\
\hline Anneberg Hus & 4,6 \\
\hline Trelleborg Huse & 4,5 \\
\hline Scanda Huse & 2,8 \\
\hline Andre & 33,2 \\
\hline Total & 100 \\
\hline *: Oprettet i den sidste efterkrigstid. Kilde: Henvisninger under Appendix VI.
\end{tabular}


Tabel IV.11. Øvrige producenter af typesommerhuse til hovedstadsmetropolens sommerhusbyer, 1974-1990

\begin{tabular}{|l|l|l|}
\hline Jeppesens Savværk & Fribo Huset & Abo Byg* \\
\hline Tectum & Anni Huset* & ETO Sommerhuse \\
\hline Møllebæk Hus & Safari Huset & Smidstrup Huset \\
\hline Ganløse Huset & Liljehuset & Friberg Hus \\
\hline Viksjø Hus & GNT Huse & H+H Gasbeton \\
\hline Tønder Hytter & AM Huset & GM Huse \\
\hline Pernille Huset* & Ringkøbing Husene * & Rævbæk Huset \\
\hline Seets Huset & Toppeved Fritidshuse* & Møllegården \\
\hline Rex Huset* & Møllebæk Huse & Trybo Typehuse \\
\hline BMF Fritidshuse & Planet Huse* & \\
\hline & & \\
\hline
\end{tabular}

*: Oprettet i den sidste efterkrigstid. Kilde: Henvisninger under Appendix VI.

Blandt de fjerde mest solgte havde Frinees Huset, der også havde rødder i den første efterkrigstids sommerboom, men ikke i perioden nåede op blandt de mest forekommende i hovedstadsmetropolen, med knapt 8 procent af den sidste efterkrigstids nye typesommerhuse overtaget Skarridsø Husenes plads, mens velkendte, men i samtiden lidt altmodisch Myresjö Huset var rykket ned på femtepladsen med godt seks procent. I blandt de øvrige mest udbredte nye typesommerhuse indgik med hver 3-5 procent af disse Trelleborg Hus, Scanda Huse og Annebreghus, der tillige alle hørte til blandt den første efterkrigstids ti mest forekommende typesommerhuse.

Derimod gled de ganske udbredte typesommerhuse fra Tectum sammen med de prisbillige fra Jeppesen Savværk, Ganløse Huset og Tårnby Huset ud af den sidste efterkrigstids toptibestsellerliste, der til gengæld kom til at omfatte Høm Huse og EBK Huse. Høm Huse forekom også i typesommersommerhusudgaver i den første efterkrigstid, men ikke i et sådan omfang, at de placerede sig blandt de ti mest forekommende i hovedstadsmetropolen. EBK Huse, der blev en af den sidste efterkrigstids større typesommerhusproducenter, blev oprette i 1976 i Slagelse, og fremstillede siden på landsplan 3.000 sommerhuse på mellem 70 og $80 \mathrm{~m}^{2}$ Af de større producenter af typesommerhuse, der etableredes i den sidste efterkrigstid, blev den i 1988 oprettede virksomhed Planet Huse, der med produktionssted i Ribe, siden kom til at rejse 2.000 huse på landsplan, hvoraf dog ingen af disse blev repræsenteret i periodens sommerhusbyer i hovedstadsmetropolen.
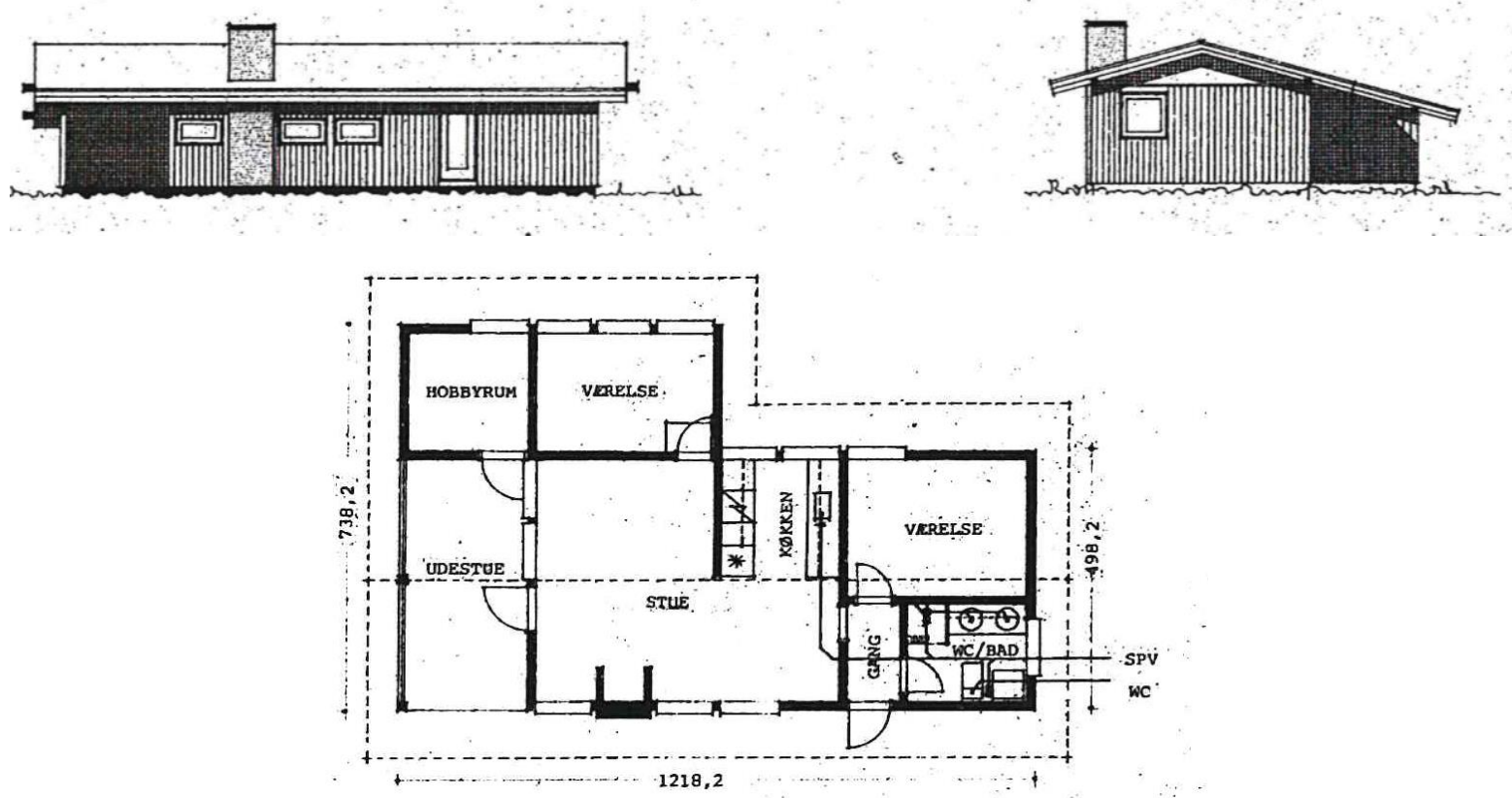

Trods den sidste efterkrigstids krise i typesommerhusbranchen blev der plads til enkelte nye virksomheder. Bl.a. Feriesta $A / S$, der fremstillede det ganske udbredte Friness Hus. Her et fra 1987 i sommerhusbyen Gershøj (Frederikssund Kommune, digitale byggesager, https://www.weblager.dk/) 

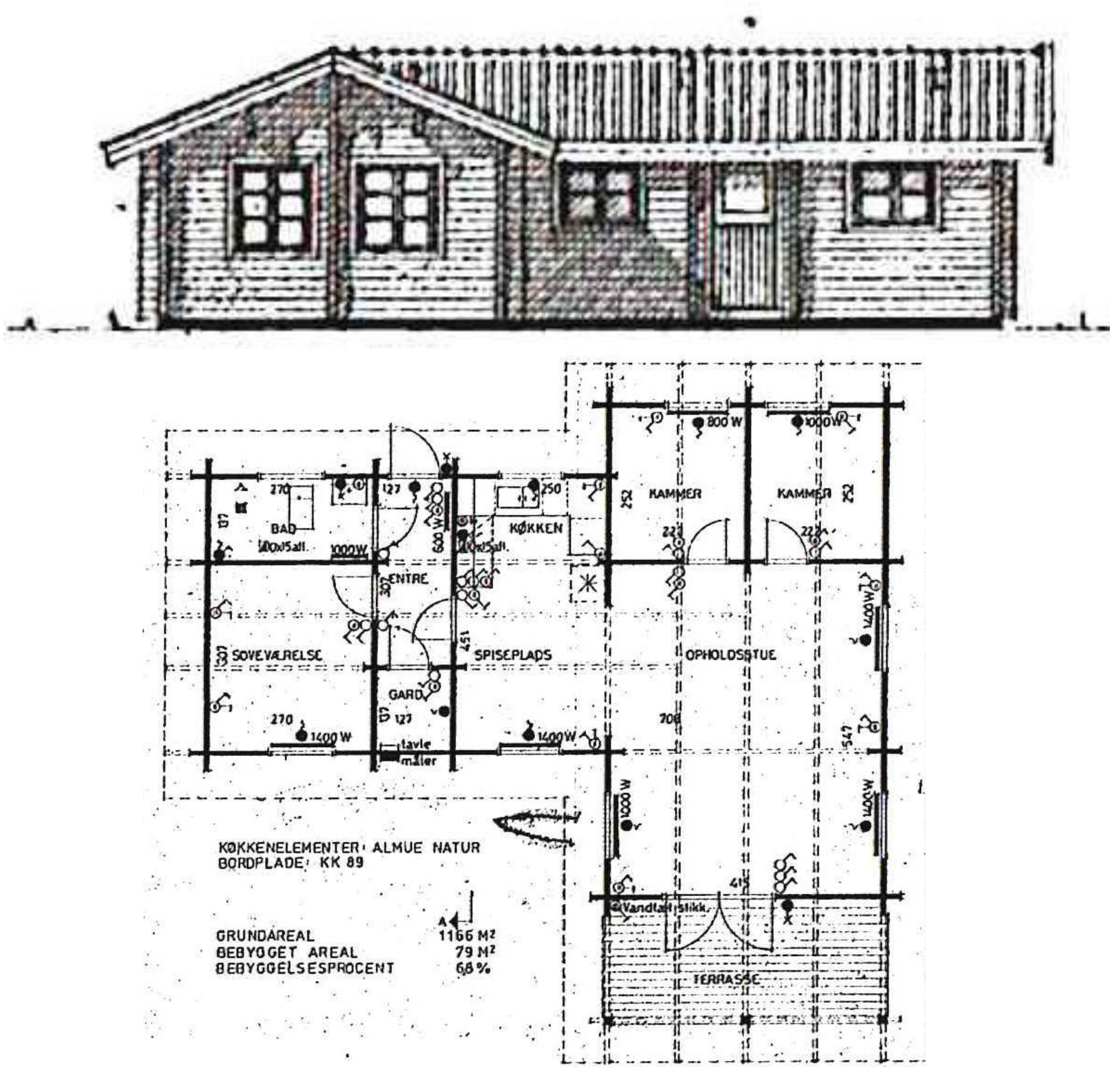

Et af Høm Husene i sommerhusbyen i Gershøj i 1978. Firmaet havde også rødder tilbage i den første efterkrigstid, men slog mere igennem i den sidste del af perioden med de robuste blokhuse (Frederikssund Kommune, digitale byggesager, https://www.weblager.dk/)

Som i alle andre dele i en kapitalistisk markedsøkonomi førte krisen i typesommerhusbranchen til en ubønhørlig udrensning af markedets svageste. Den hårdere konkurrence udslettede således $i$ et stort antal den første efterkrigstids store antal mindre typesommerhusproducenter - og importører, der havde leveret til hovedstadsmetropolens sommerhusbyer. Med denne koncentration i erhvervet reduceredes det samlede antal virksomheder til 39 i den sidste efterkrigstid mod 67 i den første del af perioden.

Blandt de 29, der ikke kom med i den sidste efterkrigstids toptibestsellerliste i hovedstadsmetropolen, indgik som før angivet i stærkt decimeret form huse fra fire af den første efterkrigstids store producenter af typesommerhuse samt huse fra 19 andre mindre, der 
heller ikke opnåede en placering på denne periodes bestsellerlisten (tabel IV. 11). Af de nævnte 29 var syv producenter opstået i den sidste efterkrigstid. En følge af at reduktionen af den første efterkrigstids små og mange virksomheder på området havde levnet plads til, at den sidste efterkrigstids ikke bestsellernoterede typesommerhusleverandører, trods peiodens markant mindre sommerhusbyggeri, i gennemsnit hver kom til at stå for i gennemsnit 62 huse, mod 55 i den første efterkrigstid. ${ }^{12}$

\section{Nye fænomener}

I en kombination af løftet af standarden i nye sommerhuse og tilbagevendende økonomiske kriser opstod i den sidste efterkrigstid desuden to nye fænomener i både hovedstadsmetropolens og det øvrige lands sommerhusbyer i form af helårsbeboelse af sommerhuse og udlejning af sådanne.

\section{Helårsbeboelse}

Med den standardopgradering, som kom til at kendetegne en betydelige del af den nye sommerhusmasse i den sidste efterkrigstid, blev helårsbeboelse $\mathrm{i}$ et sommerhus under indtryk af periodens økonomiske kriser således stadig mere udbredt i perioden. Særlig blandt ældre, der hidtil havde beboet en lejlighed og på den måde kunne få mulighed for at opnå en havebolig til en lavere prioritets- og ejendomsskattebetaling end ved erhvervelse af et enfamiliehus. Helårsbeboelse af sommerhuse var ikke tilladt ifølge, de bestemmelser landets sommerhusbyer ved underlagt via udstykningsdeklarationer, lokalkommunale bygnings- og byplanvedtægter, regionale byudviklingsplaner og sommerhusloven fra 1972, der primært ved Danmarks efterfølgende indtræden i EF havde til formål at hindre udlændinges erhvervelse af dansk sommerhuse.

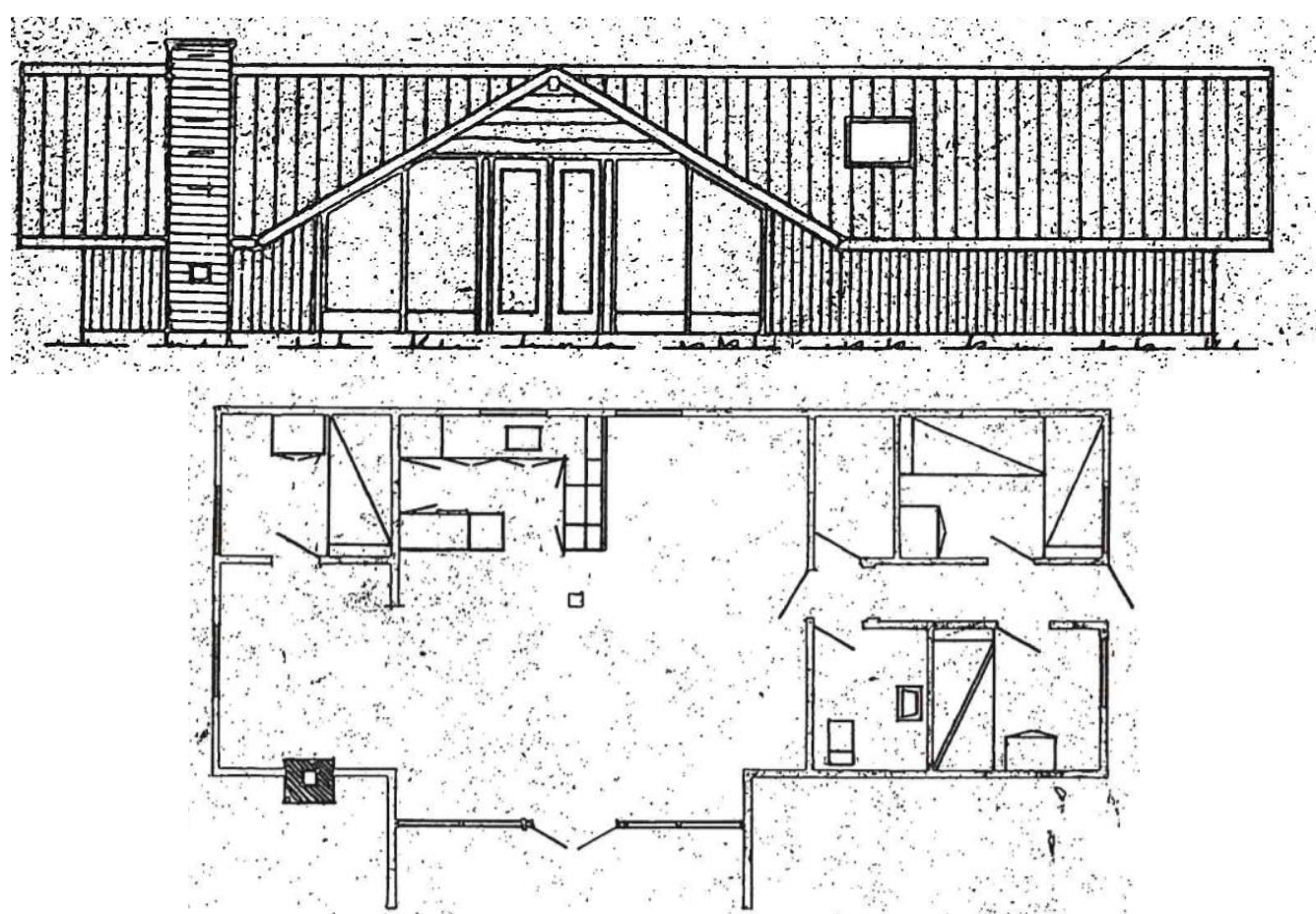

Også Kalmarhuset havde rødder i den første efterkrigstid, men det blev først i den sidste del af perioden, at det blev særdeles udredt. Her et af de karakteristiske huse i sommerhusbyen Gershøj i 1978. (Frederikssund Kommune, digitale byggesager, https://www.weblager.dk/).

Da bestemmelser og loven ikke indeholdt straffesanktioner ved overtrædelse forbuddet mod helårsbeboelse og havde uklare påtaleregler, og det de facto var muligt at flytte folkeregisteradresse til en sommerhusby, blev den ulovlige helårsbesætning her så omfattede, at den i 1980 omfattede 3.000 af landets sommerhuse. Det svarede ganske vist alene til to procent af samme, men procentandelen var højest i hovedstadsmetropolens sommerhusbyer, 
og udgjorde således ikke mindre end 34,8 i Københavns Amtskommune og 5,3 og 4,1 Frederiksborg og Roskilde amtskommuner. Selv om det for de ydre amtskommuner måske var ganske beskedne procentandele af det samlede sommerhusvolumen, svarede det til 90 procent af den ulovlige sommerhusbeboelse i hele landet. ${ }^{13}$

\section{Sommerhusudlejning}

Med de attraktioner, der knyttede sig de danske landdistrikter og kyster blev de allerede i mellemkrigstiden en central del af turistbranchens lancering af Danmark både nationalt og internationalt. Med efterkrigstidens sommerhusboom blev sommerhuset tillige sat i spil i den sammenhæng. Allerede 1959 etableredes Dansk Centralkontor for Sommerhus-Udlejning, der senere oprettede afdelinger i Tyskland.

Den blev dog først med standardforbedringer af nye sommerhuse i årene omkring 1970 og op gennem den sidste efterkrigstid, at sommerhusudlejning under indtryk af den økonomiske krise blev den dominerende branche i dansk turismeindustri, og i tiåret mellem 1984 og 1994 førte til en firedobling af omfanget af sommerhusudlejninger overvejende til lejer fra Tyskland, det $\varnothing$ vrige Skandinaven og Holland. Mens sommerhuse tidligere havde været en kompensation for det urbane pres og arbejds- og familielivet i store byer og i særlig grad $i$ hovedstadsmetropolen, blev et sommerhus en investering, der kunne give et afkast $i$ krisetider, og dermed også et motiv for erhvervelse af et sådant for samfundets mellemste og højeste indkomstlag. ${ }^{14}$

Tabel IV.12. Procentvis social sammensætning af førstegangsejere af nye sommerhuse ved Kattegatkysten, 1974-1990 og erhvervsbeskæftigede hovedstadsmetropolen, 1970 og 1990.

\begin{tabular}{|c|c|c|c|c|c|c|}
\hline \multirow[t]{3}{*}{ Stilling } & \multirow{3}{*}{\multicolumn{2}{|c|}{$\begin{array}{l}\text { Sommerhusejere, } \\
1974-1990\end{array}$}} & \multicolumn{4}{|c|}{$\begin{array}{l}\text { Hovedstadsmetropolens erhvervsbeskæftigede } \\
\text { Befolkning }\end{array}$} \\
\hline & & & \multicolumn{2}{|c|}{1970} & \multicolumn{2}{|c|}{1990} \\
\hline & & & Hovedstaden & Forstæder & Hovedstaden & Forstæder \\
\hline Større selvstændige & 10,9 & & & & & \\
\hline Mindre selvstændige & 10,0 & & & & & \\
\hline Selvstændige, total & & 20,9 & 7,1 & 9,5 & 8,1 & 7,7 \\
\hline Ledende funktionærer & 20,0 & & & & & \\
\hline Akademisk uddannede funktionærer & 12,7 & & & & & \\
\hline Højere funktionærer, i alt & 32,7 & & & & & \\
\hline Øvrige funktionærer & 38,2 & & & & & \\
\hline Funktionærer, total & & 70,9 & 42,6 & 44,6 & 59,4 & 63,8 \\
\hline Faglærte arbejdere & 8,2 & & & & & \\
\hline Ufaglærte arbejdere & 0,0 & & & & & \\
\hline Arbejdere, total & & 8,2 & 50,0 & 44,1 & 32,5 & 28,5 \\
\hline Total & 100 & 100 & 100 & 100 & 100 & 100 \\
\hline
\end{tabular}

Kilde: Henvisninger under Appendix VI.A. Bro: Hovedstadsmetropolen- den danske byregion, 2020, s. 1237-1238.

\section{Regionale variationer}

Ligesom i den første efterkrigstid kom hovedstadsmetropolens sommerhusbyer også i den sidste til regionalt at adskille sig ud fra hinanden for så vidt udbygningsgrad, sammensætning af førstegangsejere af nye sommerhus og disses størrelse og kvalitet.

\section{Kattegatkystens sommerhusbybælte}

Selv sommerhusbyerne ved Kattegatkysten i et langt større omfang end hovedstadsmetropolens $\varnothing v$ rige blev i stand til at opsuge den sidste efterkrigstids sommerhusbyggeri, blev dette i hovedsagen henvist til de meget store og senest udstykkede sommerhusbyer i Asserbo og Liseleje og den første efterkrigstids nye sommerhusbyer på Halsnæs (tabel III.12). Som i den første efterkrigstid blev den sociale sammensætning af førstegangsejere af nye sommerhuse i den sidste efterkrigstid også skæv i Kattegatkystens sommerhusbælte (tabel IV.12).

Arbejderklassens andel blev således næstmindst her, mens højtindkomstlaget af større selvstændige og højere funktionærer med 44 procent fik den højest andel i forhold til samtlige af hovedstadsmetropolens sommerhusbyer, og det lavere og mellemste indkomstlag af arbejdere, øvrige 
funktionærer og mindre selvstændige med 56 procent opnåede den mindste andel. Følgelig havde en større andel bopæl i velhaverforstæderne på Nordegen og et enfamiliehus, ligesom de stedlige sommerhuse fra den sidste efterkrigstid var i en særklasse (tabel IV.13).

Tabel IV.13. Parametre for standarden af nye sommerhuse ved Kattegatkysten, 1974-1990.

\begin{tabular}{|c|c|c|c|c|c|}
\hline \multirow[t]{2}{*}{ Opført, i procent: } & Som selvbyg & Af bygmester & Med arkitektbistand & Af byggefirma & Total \\
\hline & 1,4 & 12,1 & 27,7 & 58,8 & 100 \\
\hline \multicolumn{6}{|c|}{ Rumfordeling, i procent: } \\
\hline 1 rum & 2 rum & 3 rum & 4 rum & 5 el. fl. Rum & Total \\
\hline 0,0 & 5,1 & 36,5 & 41,1 & 17,3 & 100 \\
\hline \multirow[t]{2}{*}{ Toilet, i procent: } & Udenfor huset & I huset & Total & \multirow{2}{*}{\multicolumn{2}{|c|}{$\begin{array}{l}96,9 \text { procent med bad. } \\
\text { Alle med køkken }\end{array}$}} \\
\hline & 2,5 & 97,5 & 100 & & \\
\hline Areal: & \multicolumn{5}{|c|}{ Mellem $25-126 \mathrm{~m}^{2}$. I gennemsnit $72,7 \mathrm{~m}^{2} .98,7$ procent fuldisolerede } \\
\hline \multicolumn{3}{|c|}{ Opført, procentfordeling: } & \multicolumn{3}{|c|}{ Forsynet, procentfordeling: } \\
\hline Af træ & Som grundmuret & Total & Med skorsten & Uden skorsten & Total \\
\hline 88,1 & 11,9 & 100 & 76,3 & 23,7 & 100 \\
\hline \multicolumn{2}{|c|}{ Opført på, procentfordeling: } & \multicolumn{2}{|c|}{ Vandforsyning, procentfordeling: } & \multicolumn{2}{|c|}{ Spildevandsafledning, procentfordeling: } \\
\hline Piller & Fundament & Udenfor hus & I hus & Ingen & Sivebrønd m.m. \\
\hline 1,1 & 98,9 & 0,0 & 100 & 0,0 & 100 \\
\hline
\end{tabular}

Kilde: Henvisninger under Appendix VI.A.

I forhold til parametrene for sommerhusstandard var de nye sommerhusene ved Kattegats kyst ikke blot de største og udgjorde dem, der havde den højeste andel med 4 eller flere værelser, fuldisolering, skorsten og installeret bad, men var også dem, hvor arkitektbistand ved opførelsen hade været mest udbredt. Det standardiserede og upersonlige typesommerhus fik dermed også den mindste udbredelse ved den nordsjællandske kyset. ${ }^{15}$

Tabel IV.14. Procentvis social sammensætning af førstegangsejere af nye sommerhuse i sommerhusbyerne ved Roskilde Fjords nord- og østside, 1974-1990, og erhvervsbeskæftigede i hovedstadsmetropolen, 1970 og 1990.

\begin{tabular}{|c|c|c|c|c|c|c|}
\hline \multirow[t]{3}{*}{ Stilling } & \multirow{3}{*}{\multicolumn{2}{|c|}{$\begin{array}{l}\text { Sommerhusejere, } \\
1974-1990\end{array}$}} & \multicolumn{4}{|c|}{$\begin{array}{l}\text { Hovedstadsmetropolens erhvervsbeskæftigede } \\
\text { Befolkning }\end{array}$} \\
\hline & & & \multicolumn{2}{|c|}{1970} & \multicolumn{2}{|c|}{1990} \\
\hline & & & Hovedstaden & Forstæder & Hovedstaden & Forstæder \\
\hline Større selvstændige & 9,9 & & & & & \\
\hline Mindre selvstændige & 18,4 & & & & & \\
\hline Selvstændige, total & & 28,3 & 7,1 & 9,5 & 8,1 & 7,7 \\
\hline Ledende funktionærer & 9,8 & & & & & \\
\hline Akademisk uddannede funktionærer & 6,4 & & & & & \\
\hline Højere funktionærer, i alt & 16,2 & & & & & \\
\hline$\varnothing$ vrige funktionærer & 44,7 & & & & & \\
\hline Funktionærer, total & & 60,9 & 42,6 & 44,6 & 59,4 & 63,8 \\
\hline Faglærte arbejdere & 9,8 & & & & & \\
\hline Ufaglærte arbejdere & 1,0 & & & & & \\
\hline Arbejdere, total & & 10,8 & 50,0 & 44,1 & 32,5 & 28,5 \\
\hline Total & 100 & 100 & 100 & 100 & 100 & 100 \\
\hline
\end{tabular}

Kilde: Henvisninger under Appendix VI.B. Bro: Hovedstadsmetropolen- den danske byregion, 2020, s. 1237-1238.

\section{Roskilde Fjords nord- og østside}

Mens sommerhusbyerne ved Roskilde Fjord nord- og østside i forhold til den første efterkrigstid som helhed opsugede en langt mindre andel af den sidste efterkrigstids sommerhuse, gjaldt dette ikke for den senest udstykkede og bebyggede St. Havelse Strand, hvor andelen af denne periodes sommerhus fik en markant større andel end i den forudgående (tabel III.18). Den store og ligeledes senere udstykkede og bebyggede sommerhusby Jyllinge opsugede også i den sidste efterkrigstid over omkring 46 procent af de nye sommerhuse ved Roskilde Fjord nord- og østlige del, men i forhold det store antal udparcellerede grunde ikke i samme omfang, da disse i perioden i overvejende grad bebyggedes med enfamiliehuse.

I modsætning til Kattegatkystens sommerhusbybælte blev den social sammensætning af førstegangsejere af nye sommerhus i Roskilde Fjords kystbælte mere nævn og lagde sig tæt ved gennemsnittet for hele hovedstadsmetropolen (tabel IV.14). Dog således, at højindkomstlaget af højere funktionærer og større selvstændige med en andel på 26 procent 
og gruppen med mindre- og mellemindkomster fra arbejderklassen og laget af øvrige funktionærer og mindre selvstændige med 74 procent blev henholdsvis i større og mindre omfang repræsenteret som førstegangsejere af nye sommerhuse end i hovedstadsmetropolens sommerhusbyer som helhed.

Tabel IV.15. Parametre for standarden for nye sommerhusbyer, Roskilde Fjords nord- og østside, 1974-1990.

\begin{tabular}{|c|c|c|c|c|c|}
\hline \multirow[t]{2}{*}{ Opført, i procent: } & Som selvbyg & Af bygmester & Med arkitektbistand & Af byggefirma & Total \\
\hline & 0,0 & 19,4 & 17,7 & 62,9 & 100 \\
\hline \multicolumn{6}{|c|}{ Rumfordeling, i procent: } \\
\hline 1 rum & 2 rum & 3 rum & 4 rum & 5 el. fl. Rum & Total \\
\hline 0,0 & 4,6 & 56,3 & 28,1 & 11,0 & 100 \\
\hline \multirow[t]{2}{*}{ Toilet, i procent: } & Udenfor huset & I huset & Total & \multirow{2}{*}{\multicolumn{2}{|c|}{$\begin{array}{l}80,4 \text { procent med bad. } \\
\text { Ingen uden køkken }\end{array}$}} \\
\hline & 1,1 & 98,9 & 100 & & \\
\hline Areal: & \multicolumn{5}{|c|}{ Mellem $24-126 \mathrm{~m}^{2}$. I gennemsnit $67,5 \mathrm{~m}^{2} .99,8$ procent fuldisolerede. } \\
\hline \multicolumn{3}{|c|}{ Opført, procentfordeling: } & \multicolumn{3}{|c|}{ Forsynet, procentfordeling: } \\
\hline Af træ & Som grundmuret & Total & Med skorsten & Uden skorsten & Total \\
\hline 95,8 & 4,2 & 100 & 74,4 & 25,5 & 100 \\
\hline \multicolumn{2}{|c|}{ Opført på, procentfordeling: } & \multicolumn{2}{|c|}{ Vandforsyning, procentfordeling: } & \multicolumn{2}{|c|}{ Spildevandsafledning, procentfordeling: } \\
\hline Piller & Fundament & Udenfor hus & I hus & Ingen & Sivebrønd m.m. \\
\hline 0,0 & 100 & 0,0 & 100 & 0,0 & 100 \\
\hline
\end{tabular}

Kilde: Henvisninger under Appendix VI.B.

Med det solide indkomstgrundlag, som i den sidste efterkrigstid kendetegnede førstegangsejerne af nye sommerhuse ved Roskilde Fjords nord- og østside, havde en større andel af disse bopæl i nordforstæderne og forstæderne på Nordvestegnen og i et enfamiliehus, ligesom kystbæltets nye sommerhuse i kvalitet og størrelse lagde sig over sommerhusene i hovedstadsmetropolen som helhed (tabel IV.15). Selv om andelen af sommerhuse med 4 eller flere værelser i fjordbæltet svarede til metropolens gennemsnitssommerhus, var de arealmæssigt større, havde relativt flere tre værelses, var i højere grad fuldisolerede og udrustet med skorsten og opført af en håndsværksmester og med arkitektbistand. ${ }^{16}$

Tabel 16. Procentvis social sammensætning af førstegangsejere af nye sommerhuse i Hornsherred, 1974-1990, og erhvervsbeskæftigede i hovedstadsmetropolen, 1970 og 1990.

\begin{tabular}{|c|c|c|c|c|c|c|}
\hline \multirow[t]{3}{*}{ Stilling } & \multirow{3}{*}{\multicolumn{2}{|c|}{$\begin{array}{l}\text { Sommerhusejere, } \\
1974-1990\end{array}$}} & \multicolumn{4}{|c|}{$\begin{array}{l}\text { Hovedstadsmetropolens erhvervsbeskæftigede } \\
\text { Befolkning }\end{array}$} \\
\hline & & & \multicolumn{2}{|l|}{1970} & \multicolumn{2}{|l|}{1990} \\
\hline & & & Hovedstaden & Forstæder & Hovedstaden & Forstæder \\
\hline Større selvstændige & 6,1 & & & & & \\
\hline Mindre selvstændige & 15,4 & & & & & \\
\hline Selvstændige, total & & 21,5 & 7,1 & 9,5 & 8,1 & 7,7 \\
\hline Ledende funktionærer & 10,1 & & & & & \\
\hline Akademisk uddannede funktionærer & 7,0 & & & & & \\
\hline Højere funktionærer, i alt & 17,1 & & & & & \\
\hline$\varnothing v$ rige funktionærer & 44,6 & & & & & \\
\hline Funktionærer, total & & 61,7 & 42,6 & 44,6 & 59,4 & 63,8 \\
\hline Faglærte arbejdere & 16,1 & & & & & \\
\hline Ufaglærte arbejdere & 0,7 & & & & & \\
\hline Arbejdere, total & & 16,8 & 50,0 & 44,1 & 32,5 & 28,5 \\
\hline Total & 100 & 100 & 100 & 100 & 100 & 100 \\
\hline
\end{tabular}

Kilde: Henvisninger under Appendix VI.C. Bro: Hovedstadsmetropolen- den danske byregion, 2020, s. 1237-1238.

\section{Hornsherred}

Selv om Hornsherreds sommerhusbyer som helhed opsugede relativt flere sommerhuse i den sidste efterkrigstiden, blev det i højere grad de senest udstykkede og bebyggede på halvøens Roskilde Fjord-side og mellemste del ved kyststrækningen ud til Isefjorden, der blev i stand til det (tabel III.25). I forhold til den gennemsnitlige sociale sammensætning af førstegangsejere af nye sommerhuse i hovedstadsmetropolens sommerhusbyer som helhed, blev den mere lige i Hornsherred (tabel IV.16). Med næsten 17 procent af ejergruppen opnåede arbejderklassen således her den største repræsentation, mens højindkomstlaget af større selvstændig og højere funktionærer blev mindst og lav- og mellemindkomstgruppen af arbejdere, øvrige funktionærer og mindre selvstændige tilsvarende størst. Det blev også blandt førstegangsejere 
af nye sommerhuse i Hornherred, at beboelse af lejligheder i etagebyggeri og bopæl i hovedstaden og i Vest- og Nordvestegnens forstæder blev mest udbredt.

\begin{tabular}{|c|c|c|c|c|c|}
\hline \multirow[t]{2}{*}{ Opført, i procent: } & Som selvbyg & Af bygmester & Med arkitektbistand & Af byggefirma & Total \\
\hline & 6,3 & 13,8 & 7,2 & 72,7 & 100 \\
\hline \multicolumn{6}{|c|}{ Rumfordeling, i procent: } \\
\hline 1 rum & 2 rum & 3 rum & 4 rum & 5 el. fl. Rum & Total \\
\hline 0,0 & 9,4 & 59,4 & 24,5 & 6,7 & 100 \\
\hline \multirow[t]{2}{*}{ Toilet, i procent: } & Udenfor huset & I huset & Total & \multirow{2}{*}{\multicolumn{2}{|c|}{$\begin{array}{l}77,9 \text { procent med bad. } \\
\text { Ingen uden køkken }\end{array}$}} \\
\hline & 1,9 & 98,5 & 100 & & \\
\hline Areal: & \multicolumn{5}{|c|}{ Mellem 31-132 $\mathrm{m}^{2}$. I gennemsnit $64,6 \mathrm{~m}^{2} .91,7$ procent fuldisolerede } \\
\hline \multicolumn{3}{|c|}{ Opført, procentfordeling: } & \multicolumn{3}{|c|}{ Forsynet, procentfordeling: } \\
\hline Af træ & Som grundmuret & Total & Med skorsten & Uden skorsten & Total \\
\hline 94,5 & 5,5 & 100 & 58,3 & 41,7 & 100 \\
\hline \multicolumn{2}{|c|}{ Opført på, procentfordeling: } & \multicolumn{2}{|c|}{ Vandforsyning, procentfordeling: } & \multicolumn{2}{|c|}{ Spildevandsafledning, procentfordeling } \\
\hline Piller & Fundament & Udenfor hus & I hus & Ingen & Sivebrønd m.m. \\
\hline 0,9 & 99,1 & 0,0 & 100 & 0,0 & 100 \\
\hline
\end{tabular}

Kilde: Henvisninger under Appendix VI.C.

Blandt den sidste efterkrigstids sommerhuse i hovedstadsmetropolens sommerhusbyer, blev dem i Hornsherred da også mindst og mindre veludrustede (tabel IV.17). Det gjaldt: Et gennemsnitsarealet på godt $64 \mathrm{~m}^{2}$, en langt henholdsvis mindre og større andel af huse med flere end fire værelser og huse alene med to værelser, omfanget af fuldisolering, installerede badefaciliteter og skorstene. Endelig udgjorde selvbyggere og typesommerhuse den største andel i Hornsherred. ${ }^{17}$

Tabel 18. Procentvis social sammensætning af førstegangssommerhusejere i øvrige sommerhusbyer, 1974-1990, og af erhvervsbeskæftigede i hovedstadsmetropolen, 1970 og 1990.

\begin{tabular}{|c|c|c|c|c|c|c|}
\hline \multirow[t]{3}{*}{ Stilling } & \multirow{3}{*}{\multicolumn{2}{|c|}{$\begin{array}{l}\text { Sommerhusejere, } \\
1974-1990\end{array}$}} & \multicolumn{4}{|c|}{$\begin{array}{l}\text { Hovedstadsmetropolens erhvervsbeskæftigede } \\
\text { Befolkning }\end{array}$} \\
\hline & & & \multicolumn{2}{|l|}{1970} & \multicolumn{2}{|l|}{1990} \\
\hline & & & Hovedstaden & Forstæder & Hovedstaden & Forstæder \\
\hline Større selvstændige & 14,4 & & & & & \\
\hline Mindre selvstændige & 18,9 & & & & & \\
\hline Selvstændige, total & & 33,3 & 7,1 & 9,5 & 8,1 & 7,7 \\
\hline Ledende funktionærer & 10,2 & & & & & \\
\hline Akademisk uddannede funktionærer & 13,0 & & & & & \\
\hline Højere funktionærer, i alt & 23,2 & & & & & \\
\hline Øvrige funktionærer & 37,7 & & & & & \\
\hline Funktionærer, total & & 60,9 & 42,6 & 44,6 & 59,4 & 63,8 \\
\hline Faglærte arbejdere & 5,8 & & & & & \\
\hline Ufaglærte arbejdere & 0,0 & & & & & \\
\hline Arbejdere, total & & 5,8 & 50,0 & 44,1 & 32,5 & 28,5 \\
\hline Total & 100 & 100 & 100 & 100 & 100 & 100 \\
\hline
\end{tabular}

Kilde: Henvisninger under Appendix VI.D. Bro: Hovedstadsmetropolen- den danske byregion, 2020, s. 1237-1238.

\section{Øvrige sommerhusbyer}

Da størsteparten af hovedstadsmetropololens øvrige sommerhusbyer tidligt var blevet udstykket og bebygget i større omfang, og en del efterhånden overgået til helårsbeboelse, kom disse i langt mindre omfang end i den første efterkrigstid til at opsuge den sidste efterkrigstids nye sommerhuse (tabel III. 32). Dog således, at de senest udstykkede og bebyggede sommerhusbyer ved Nordsjællands store søer i Kattegatkystens fjernere bagland og den store sommerhusby Strøby Strand ved Køge Bugts sydside opnåede en større andel af den sidste efterkrigstids sommerhusbyggeri.

Netop som følge af disse sommerhusbyers større andel af den sidste efterkrigstids sommerhuse blev sammensætningen af førstegangsejere af nye sommerhuse og disses størrelse og kvalitet i perioden markant forskellig fra den første efterkrigstid i disse af hovedstadsmetropolens øvrige sommerhusbyer. Med en andel af højindkomstlaget af større selvstændig og højere funktionærer på 38 procent blandt førstegangsejere af nye sommerhuse 
og arbejderklassens og lav- og mellemindkomstlaget af arbejdere, øvrige funktionærer og mindre selvstændiges andel af samme på henholdsvis 6 og 62 procent, lagde den sociale sammensætning af gruppen af ejere af nye sommerhusene i den sidste efterkrigstid i hovedstademetropolens øvrige sommerhusbyer sig tæt på samme sammensætning som i sommerhusbybæltet ved Kattegatkysten (tabel IV.18).

En parallelitet, der også kendetegnede karakteren af periodens sommerhusbyggeri i disse sommerhusbyer (tabel IV.19). For såvel husenes størrelse, mængden af huse med flere end fire værelser og husenes isoleringsgrad og udrustning med badefaciliteter og skorstene, kom den sidste efterkrigstids sommerhuse i hovedstadsmetropolens øvrige sommerhusbyer næsten på niveau med periodens nye sommerhuse i sommerhusbyerne ved Kattegatkysten. ${ }^{18}$

Tabel IV.19. Parametre for standarden for nye sommerhuse, øvrige sommerhusbyer, 1974-1990.

\begin{tabular}{|c|c|c|c|c|c|}
\hline \multirow[t]{2}{*}{ Opført, i procent: } & Som selvbyg & Af bygmester & Med arkitektbistand & Af byggefirma & Total \\
\hline & 3,2 & 19,4 & 16,1 & 61,3 & 100 \\
\hline \multicolumn{6}{|c|}{ Rumfordeling, i procent: } \\
\hline 1 rum & 2 rum & 3 rum & 4 rum & 5 el. fl. Rum & Total \\
\hline 0,0 & 7,3 & 47,8 & 31,1 & 13,8 & 100 \\
\hline \multirow[t]{2}{*}{ Toilet, i procent: } & Udenfor huset & I huset & Total & \multirow{2}{*}{\multicolumn{2}{|c|}{$\begin{array}{l}89,7 \text { procent med bad. } \\
\text { Ingen uden køkken }\end{array}$}} \\
\hline & 0,0 & 100 & 100 & & \\
\hline Areal: & \multicolumn{5}{|c|}{ Mellem $30-145 \mathrm{~m}^{2}$. I gennemsnit $69,6 \mathrm{~m}^{2} .97,7$ procent fuldisolerede. } \\
\hline \multicolumn{3}{|c|}{ Opført, procentfordeling: } & \multicolumn{3}{|c|}{ Forsynet, procentfordeling: } \\
\hline Af træ & Som grundmuret & Total & Med skorsten & Uden skorsten & Total \\
\hline 85,9 & 14,1 & 100 & 73,6 & 26,4 & 100 \\
\hline \multicolumn{2}{|c|}{ Opført på, procentfordeling: } & \multicolumn{2}{|c|}{ Vandforsyning, procentfordeling: } & \multicolumn{2}{|c|}{ Spildevandsafledning, procentfordeling: } \\
\hline Piller & Fundament & Udenfor hus & I hus & Ingen & Sivebrønd m.m. \\
\hline 0,0 & 100 & 0,0 & 100 & 0,0 & 100 \\
\hline
\end{tabular}

Kilde: Henvisninger under Appendix VI.D. 


\section{Regionsudfordringen}

Op gennem de sidste efterkrigsårtier kom sommerhusbydannelser fortsat til at indgå blandt det sæt af barrierer for interaktionen i hovedstadsmetropolen og vedblev dermed at udgøre en af de mange regionsudfordringer for metropolens videre udvikling som en byregion. Hertil kom forandringer af de hidtidige sommerhusbyers karakter som følge af deres stadig større forstadspræg og omfanget af helårsbeboelser i disse.

\section{Sommerhusbyspredning}

Selv om der i den sidste efterkrigstids stærkt reducerede nybyggeri af sommerhuse kunne rummes inden for de sommerhusbyer, der allerede var opstået, repræsenterede de forsat meget betydelige regionsudfordringer. Trods 60 'erne fredningsplanmæssige dispositioner havde sommerhusbyerne ikke blot beslaglagt meget omfattende højklassede naturområder og som påvist af Landsplanudvalget i slutningen af $60^{\prime}$ ernes tillige landskaberne helt op til samtlige af de strande, der var egnet til badning og friluftsophold, men dermed også reduceret den brede befolknings adgang til og benyttelse af de sparsomme mest rekreativt og natur- og kulturhistorisk værdifulde dele af hovedstadsmetropolens åbne land. En barriere for både fastholdelse af en del af arbejdskraftens produktionsevne og interaktion mellem hovedstadsmetropolens funktionelt forskelligartede byenheder og det friluftsliv, som havde en central placering i velfærdsstatens kultur- og fritidssøjle.

Sommerhusbyernes samspil med det åbne lands stærkt tiltagende bymæssige bebyggelse og dets både rekreative og erhvervsmæssige anvendelse stod tillige tilbage fra den første efterkrigstid som betydelige regionsudfordringer. Regionale udfordringer for kapitalens mest rationelle lokalisering af boligbyggeri og erhvervsvirksomhed og offentlige myndigheders udlæg af trafik-, forsynings- og spildevandsledninger og varmeforsyningsområder. Tilsvarende regionale udfordringer knyttede sig til den spildevandbelastning og det trafikale pres på regionale veje, som sommerhusbyerne bidrog med, disses forsyningsbehov og det øgede sygehusbehandlingsbehov, som de store befolkningskoncentrationer i sommerhusbyerne bidrog til på samme tid, som hovedstadsmetropolens befolknings- og bebyggelsesmæssige tilvækst netop i den sidste efterkrigstid var størst i dens ydre amtskommuner.

Hertil føjede sig, at den buffer, som de tilbageværende ledige ubebyggede parceller i sommerhusbyerne repræsenterede, trods den sidste efterkrigstids mindre sommerhusbyggeri var ved at blive opbrugt, hvorved der var en latent risiko for yderligere sommerhusbysspredning. En risiko, der forstærkedes af, at mange ældre sommerhusbyer med deres meget betydelige omfang og moderne sommerhusbyggeri var begyndt at miste deres karakter af et regionalt rekreativt ferie- og fritidsbomiljø med dertil hørende større individuel frihed, mere rummelighed og rigere kontakt mellem beboerne. En udvikling, der skabte behov for nye udlæg af sommerhusbyer i de resterende ydre og endnu mere afsondrede dele af hovedstadsmetropolens åbne land, hvor netop højklassede naturværdier stadig stod tilbage. ${ }^{19}$

\section{Helårsbeboelse}

En udviklingstendens, der i den sidste efterkrigstid understøttedes af den stadig mere udbredte helårsbeboelse i sommerhusbyer, der fulgte med tidens større gruppe af pensionister og $ø$ konomiske lavvækst. Sommerhusbyers omdannelse til forstad havde ganske vist været kendt både i tiden før første verdenskrig og i mellemkrigstiden, hvor sommervillaerne ved Strandvejen og siden ulovligt helårsbeboede sommerhuse havde dannet grundlaget for forstadsdannelserne først på Nordegnen og senere på Nordvest- og Vestegnen og i den første efterkrigstid, hvor sommerhusbybæltet langs Køge Bugt blev opslugt af områdets massive forstadsomdannelse. Men havde ikke før i større omfang gjort sig gældende i sommerhusbyerne i hovedstadsmetropolens ydre dele. 
Med mere udbredte helårsbeboelse i disse sommerhusbyer var der en risiko for, at disse overtid forvandledes til bydannelser svarende hovedstadsmetropolens øvrige satellitbyer, hvilket ville reducerer den begrænsede mængde af regionale byområder til rekreativ fritidsbeboelse, øge sommerhusbysspredningen og underminere sommerhusbyens karakter og tilknyttede fællesanlæg til anvendelse for et kortvarigt rekreativt fritidsliv. En udvikling der ikke alene ville føre til meget betydelige kommunale udgifter til kostbare udbygninger af forsynings og spildevandsanlæg og velfærdsydelser og-tilbud, men også ville lægge pres på hovedstadsmetropolens tilbageværende rekreative områder for den del af befolkningen med bopæl i hovedstadsmetropolens centrale del og skabe behov for udlæg af yderlige sommerhusbyer med deraf følgende nye regionsudfordringer. ${ }^{20}$ 


\section{Regions- og sektorplanlægning}

Mens reguleringen og planlægningen af hovedstadsmetropolens sommerhusbyggeri og udbredelse af sommerhusbyer op gennem den første efterkrigstid alene regionalt havde styret 60 'ernes fredningsplanlægning, konkrete fredninger og fredningsmyndigheders og amtskommuners beføjelser i forhold til sommerhusudstykninger og- byggeri i det åbne land, blev der i den sidste efterkrigstid givet muligheder for en gennemgribende inddæmning af den regionsudfordring, som sommerhusbydannelsen udgjorde. Forudsætningen herfor blev det regionskommunale kommunale organ, der i 1974 oprettedes for hele hovedstadsmetropolen og de regions- og sektorplanområder med tilhørende administrative og tilsynsmæssige beføjelser på disse områder, der tillagdes dette. Planområder og administrations- og tilsynsfunktioner, som kom til at omfavne samtlige af hovedstadsmetropolens regionsudfordringer, og dermed også dem sommerhusbyerne repræsenterede. Et kvantespring $\mathrm{i}$ forhold til den hidtidige håndtering af metropolens regionsudfordringer.

\section{Regionsplanlægning}

Havde den regionale byspredning, fordeling af bebyggelsesarter og udlæg af rekreative områder i hovedstadsmetropolen alene indgået som planfaktorer i den første efterkrigstids egnsplansskitser, og havde været forsøgt implementeret af forskellige statslige myndiggeder, byudviklings- og fredningsplanudvalg samt Køge Bugt-planlægningsudvalget, samledes denne hidtil fragmenterede egnsplanlægning i den sidste efterkrigstid under metropolens regionskommunale organs regionsplanlægning. En planform, der således fik karakter af en egentlig regional fysisk planlægning, som tillige kom til at omfatte samtlige regionale fysiske aspekter af den øvrige planlægningsmæssige og politisk-administrative håndtering af hovedstadsmetropolens regionsudfordringer, som organet tillige skulle varetage. Regionsplanlægningen blev dermed den samlende fysiske krumtap for løsningen af hovedstadsmetropolens regionale udfordringer og for det regionskommunale organs virke.

\section{Regionale politisk-administrative forudsætninger}

Selv om der siden mellemkrigstiden var gjort adskillelige forsøg på at omlægge hovedstadsmetropolens kommunale politisk-administrative rammestruktur $\mathrm{i}$ forhold til dens udfordringer, blev det først i forlængelse af kommunalreformen i 1970, at der blev fundet en løsning på den regionsudfordring, som denne rammestruktur i sig selv udgjorde.

Under indtryk af hovedstadsmetropolens tiltagende regionale udfordringer nedsattes således i 1971 Hovedstadsreformudvalget, der skulle tilpasse metropolens særegne kommunalstruktur til kommunalreformens grundprincipper. Af hensyn til det i hovedstademetropolen politisk stadig betændte indlemmelsesspørgsmål afstod udvalget fra at fremkomme med forslag til kommunesammenlægninger, men overførte til gengæld et af kommunalreformens principper, "én by, én kommune", til hele metropolen i form af forslag til oprettelse af et regionskommunalt organ; Hovedstadsrådet.

Et overregionalt kommunalt organ, der skulle løse størsteparten af hovedstadsmetropolens regionale udfordringer og lå over de to hovedstadskommuner, der bevarede funktionen som primær- og amtskommuner, metropolens primærkommuner, de hidtidige købstadskommuner $\mathrm{i}$ købstadsringen, semikøbstadskommunale forstadskommuner og øvrige sognekommuner, samt de tre amtskommuner. Uden væsentlige ændringer blev Hovedstadsreformudvalget forslag i 1973 gennemført som lov om oprettelse af Hovedstadsrådet med virkning fra 1.april 1974 sammen med ledsagende anden lovgivning, der udfyldte rammerne for de regionsopgaver, som tillagdes rådet og den meget betydelige regionsforvaltning, som dette senere opbyggede. I lovpakken i forbindelse med Hovedstadsrådets oprettelse indgik den for kommunerne bindende regionsplanlægningen, som rådet skulle gennemføre i hovedstadsmetropolen og som 
omfattede en vidtfavnende fysisk planlægning i alle dens aspekter. En regional planopgave, der dog i mindre omfang, samtidig tillagdes de øvrige af landets ny amtskommuners stærkt udvidede opgaveportefølje ved gennemførelse af lovgivningen om lands- og regionsplanlægning. ${ }^{21}$

\section{Regional byspredning og fysisk planlægning}

Selv om hovedparten af landets byområder og nærmeste oplande siden byudviklingsloven i 1949 var blevet udlagt som byudviklingsområder, og der var udarbejdet gældende byudviklingsplaner herfor, havde loven og anden lovgivning ikke kunnet hindre bymæssig bebyggelse i det åbne land, hvorved der blev gjort indhug i de naturområder og rekreative områder, der ikke var omfattet af fredninger, fredningsplaner eller sikret på andre måder. Da der desuden var behov for at samle en række af bestemmelserne om bebyggelse i det åbne land under ét, gennemførtes i 1969 by- og landzoneloven, hvis gennemførelse forventedes tillagt og senere tillagdes de nye amtskommuners og Hovedstadsrådets regionsplanlægning.

Mens 1949-byudviklingslovens zonering hidtil alene have omfattet de dele af landet, som var udlagt til byudviklingsområder, skulle hele landet med by- og landzoneloven inddeles i by- eller landzone. I byudviklingsområder blev zoneudlægning i første omgang overladt til de eksisterende byudviklingsudvalg, mens den uden for skulle gennemføres af amtskommunerne, der sammen med Hovedstadsrådet for hovedstadsmetropolens område fik denne opgave i fuldt omfang fra 1975, hvor byudviklingsområderne og de dertil hørende byudviklingsudvalg ophævedes. Byzoner blev fastlagt til områder, der allerede i en byudviklingsplan var udlagt som inder- eller mellemzone eller som en bygnings- eller byplanvedtægt var udlagt som bymæssig bebyggelse eller til offentlige formål. Ved udlæggelse af nye byzoner skulle disse have et omfang, så der, i forhold til egnen som helhed og en kommende hensigtsmæssig byplanlægning, kunne tilvejebringes tilstrækkelige arealer til dækning af de kommende 12 àrs behov for opførelse af bolig- og erhvervsbebyggelser samt til offentlige og rekreative formål.

Landzoner blev den øvrige del af landet, der ikke var omfattet af definitionen for en byzone eller som i en byplans- eller bygningsvedtægt ikke var udlagt som såkaldte sommerhusområder. I landzoner måtte der af hensyn til beskyttelsen af det åbne lands landskabelige og rekreative værdier, alene gennemføres udstykninger og bebyggelser, der havde betydning for land- og skovbrugsmæssig drift og fiskerierhverv, og bestående bygninger måtte alene anvendes i disse erhvervs øjemed. For så vidt udstykning, anden bebyggelse, forandret anvendelse af eksisterende bebyggelse og ubebyggede arealer, og dermed også for udstykning af og bebyggelse i nye eller udvidede sommerhusbyer, skulle der indhentes tilladelse fra amtskommunen og fra 1975 af Hovedstadsrådet. ${ }^{22}$

Inden for byzonerne skulle regionsplanen angive hovedtrækkene ved fordelingen af bybebyggelsesarterne samt omfanget og beliggenheden af overordnede centre og i randzoner regionale rekreative områder. Hertil kom indarbejdelse i regionsplanen af de rummelige dimensioner, som ville udspringe af den planlægningsmæssige og politisk-administrative håndtering af hovedstadsmetropolens øvrige udfordringer, og som indgik i den såkaldte sektorplanlægning; se nedenfor. ${ }^{23}$

\section{Fra Regionsplan 1973 til Regionsplan 1989}

Ved oprettelsen af Hovedstadsrådet overtog rådforvaltningen den Regionsplan 1973, som det i 1967 nedsatte Egnsplanrådet umiddelbart før havde offentliggjort. ${ }^{24}$ Regionsplan $1973 \mathrm{~s}$ forudsætninger hvilede på den betydelige økonomiske vækst og by- og befolkningsmæssige tilvækst, der i hovedstadsmetropolen stadig gjorde sig gældende i starten af 70 'erne.

\section{Regionsplan 1973}

Ud fra disse forudsætninger opererede Regionsplan 1973 derfor med en så omfattende beskæftigelses- og befolkningsmæssigtilvækst, at hovedstadsmetropolens befolkningstal i 1990 ansattes til 1,9 mio. og til et sted mellem 2 og $21 / 2$ mio. indbyggere efter årtusindeskiftet. Selv på den korte bane frem til 1990 skulle der ud fra den anlagte 
vækstdimension, der var præget af den første efterkrigstids vækstcenterteori, i denne periode tilvejebringes meget betydelige erhvervsarealer og byrum for 250.000 nye boliger. En mindre del af bolig- og erhvervsbyggeriet kunne placeres i de hidtidige byzoner, der ikke måtte udvides, i forstadsbåndene, hvor den hidtidige fordeling af bebyggelsesarterne skulle fastholdes. Strøsteparten af bolig- og erhvervsbyggeri var dog i Regionsplan 1973 i to byvækstsområder tænkt henlagt omkring en såkaldt hovedstruktur, der skulle opsuge størstedelen af hovedstadsmetropolens estimerede befolknings- og erhvervsmæssige vækst. Hovedstrukturen omfattede en gennemgående en km bred transportkorridor, med regionale forsyningstransmissionsledninger, motorvej og en højklasset jernbane fra Hillerød i nord til Køge i syd. I de knudepunkter, som opstod, der hvor denne transportkorridor krydsede de radiale forstadsbånd og deres trafiklinjer, i byvækstormåde 1 syd for Hillerød, ved Måløv, Høje Tåstrup og syd herfor i byvækstområde 2, sydvest for Køge, skulle der udlægges erhvervsmæssige A-zoner til industri, centeradministration og institutioner.

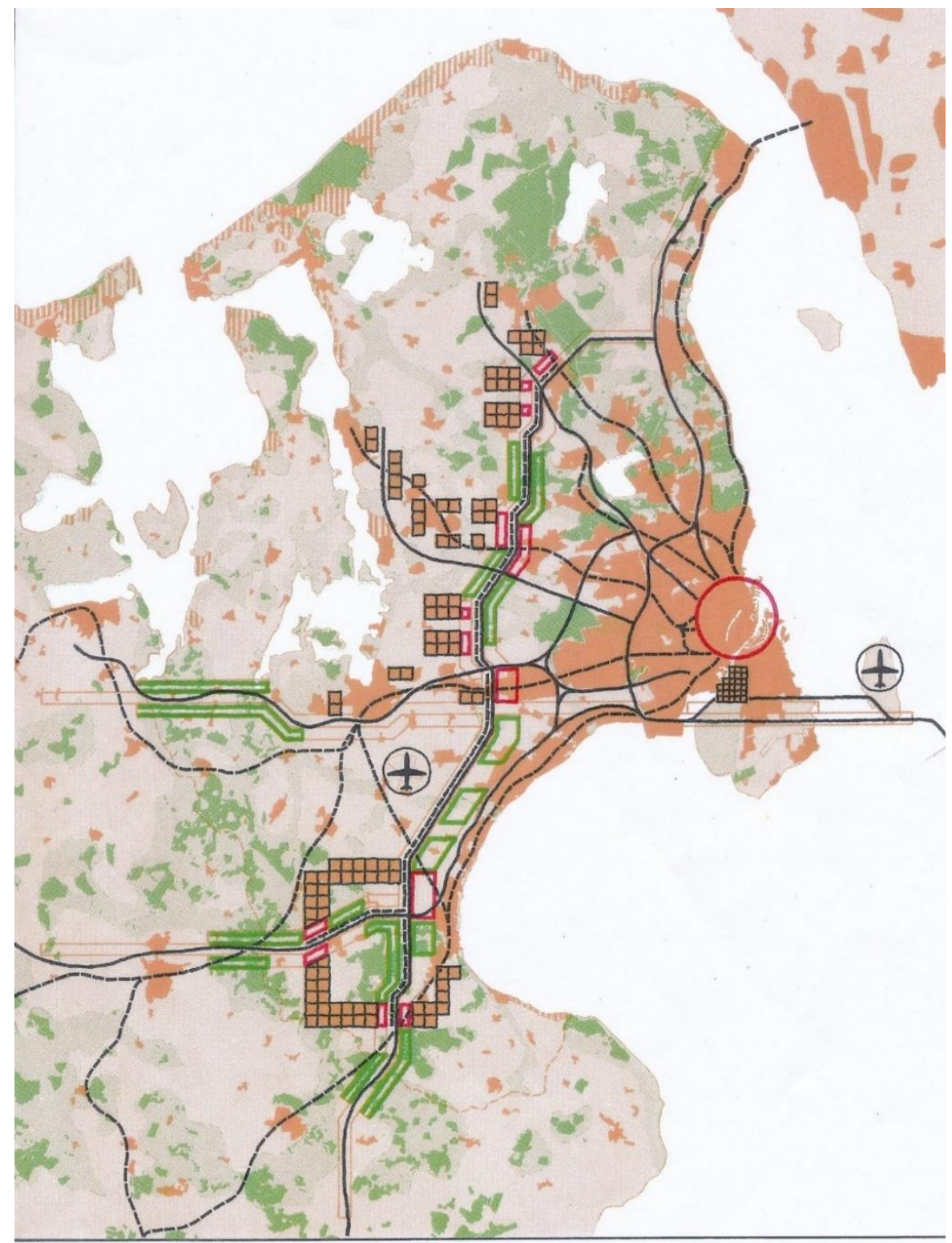

RP $1.2+1.3$ REGIONPLAN 1973, HOVEDSTRUKTUR OG BYVAEKSTFORDELING

De nye byområder $\mathrm{i}$ byvækstområde $1 \mathrm{og} 2$ er skematisk udlagt $\mathrm{i}$ enheder af $1 \mathrm{~km}^{2}(=1.000$ boliger gennem snitligt). I byvækstområde 3 er angivet 25.000 boliger. Erhvervsmæssige interesseområder i A-zonen er indrammet med rødt, rekreative interesseområder med grønt. "Værdifulde landskaber« er lysegrønne, skove mørkegrønne. Overordnede lufthavne er vist med flysymboler. Overordnede baner og veje er vist med sort.

Regionsplan 1973 (Regionsplanens 1. Etape 1977-1992, Hovedstadsrådet 1978) 


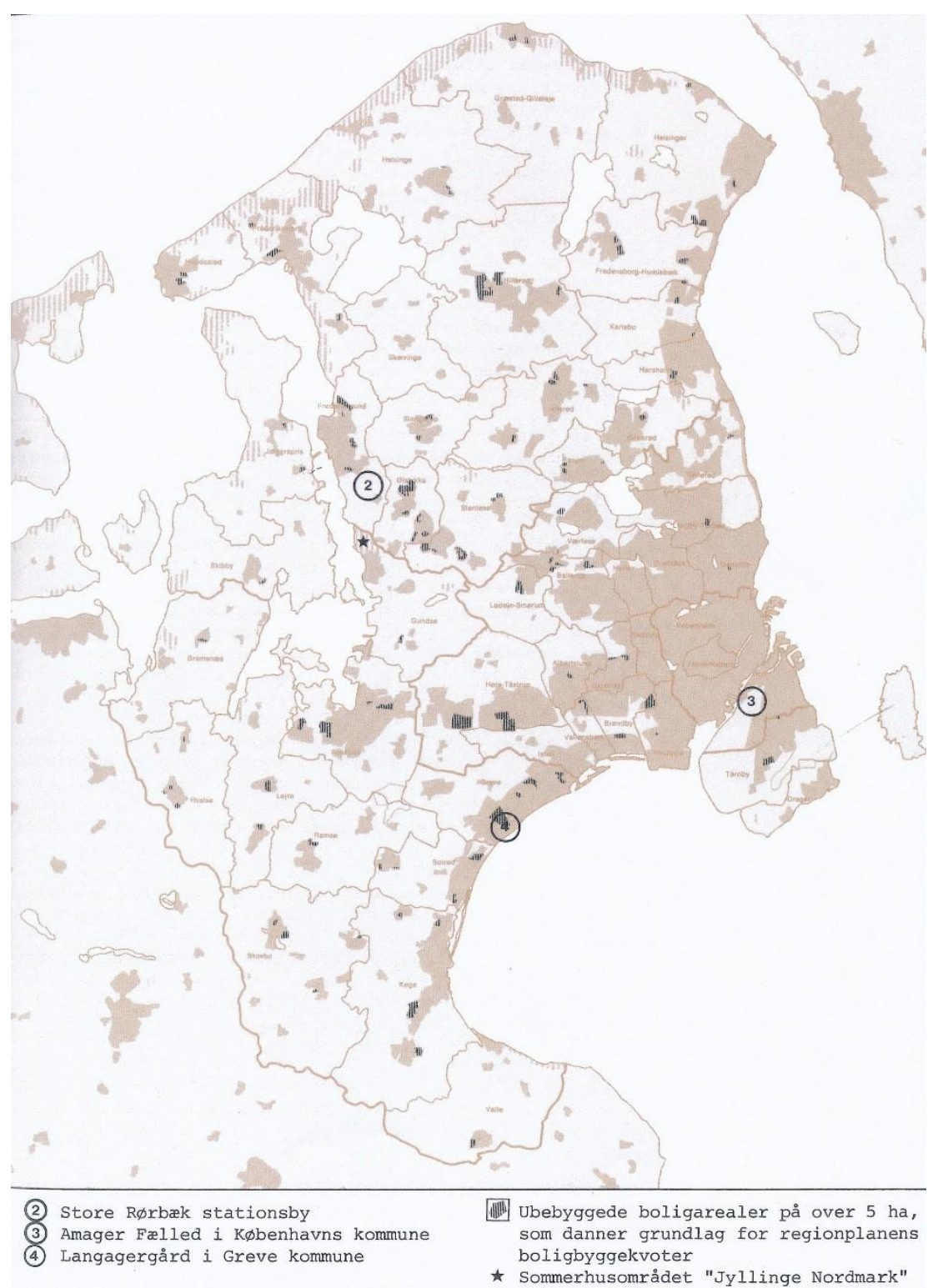

De nye boligområder i Regionsplan 1989 repræsenterede en voldsom beskæring i forhold til Regionsplan 1974 (Regionsplan 1989, Hovedstadsradet 1989)

130.000 af de nye boliger skulle efter Regionsplan 1973 placeres i et mindre byvækstområde på Vestamager, i de ydre dele af de radiale forstadsbånd frem mod Hillerød, Frederikssund og Køge samt i fire ny bydannelser mellem de erhvervsmæssige A-zoner i byvækstområde 1 syd for Hillerød i nord, i Høje Tåstrup i syd samt i byvækstomrăde 2s meget omfattende område omkring Køge. For den anden planperiode frem til på den anden side af årtusindeskiftet opererede regionsplanen med yderligere A-zoner til erhverv og nye betydelige bydannelser syd og vest for Køge.

Ud over at lokalisere de eksisterende sommerhusbyer indgik en afgræsning og nærmere planlægning af sommerhusbysspredningen i hovedstadsmetropolens åbne land, i lighed med den første efterkrigstids egnsplanskitser, ikke i Regionsplan 1973, der dog var langt mere præcis med udlæg af regionale rekreative områder, differentiering af disse og deres sammenhæng med de indre dele af metropolen og de nye bydannelser og A-zoner. I Regionsplan 1973s hovedstruktur indgik således grønne rekreative A-zoner, der skulle danne overgang herfra til de meget omfattende rekreative naturområder, som i det nordligste Nordsjælland, Hornsherred og områderne sydøst indgik i regionsplanen; se nedenfor. ${ }^{25}$ 


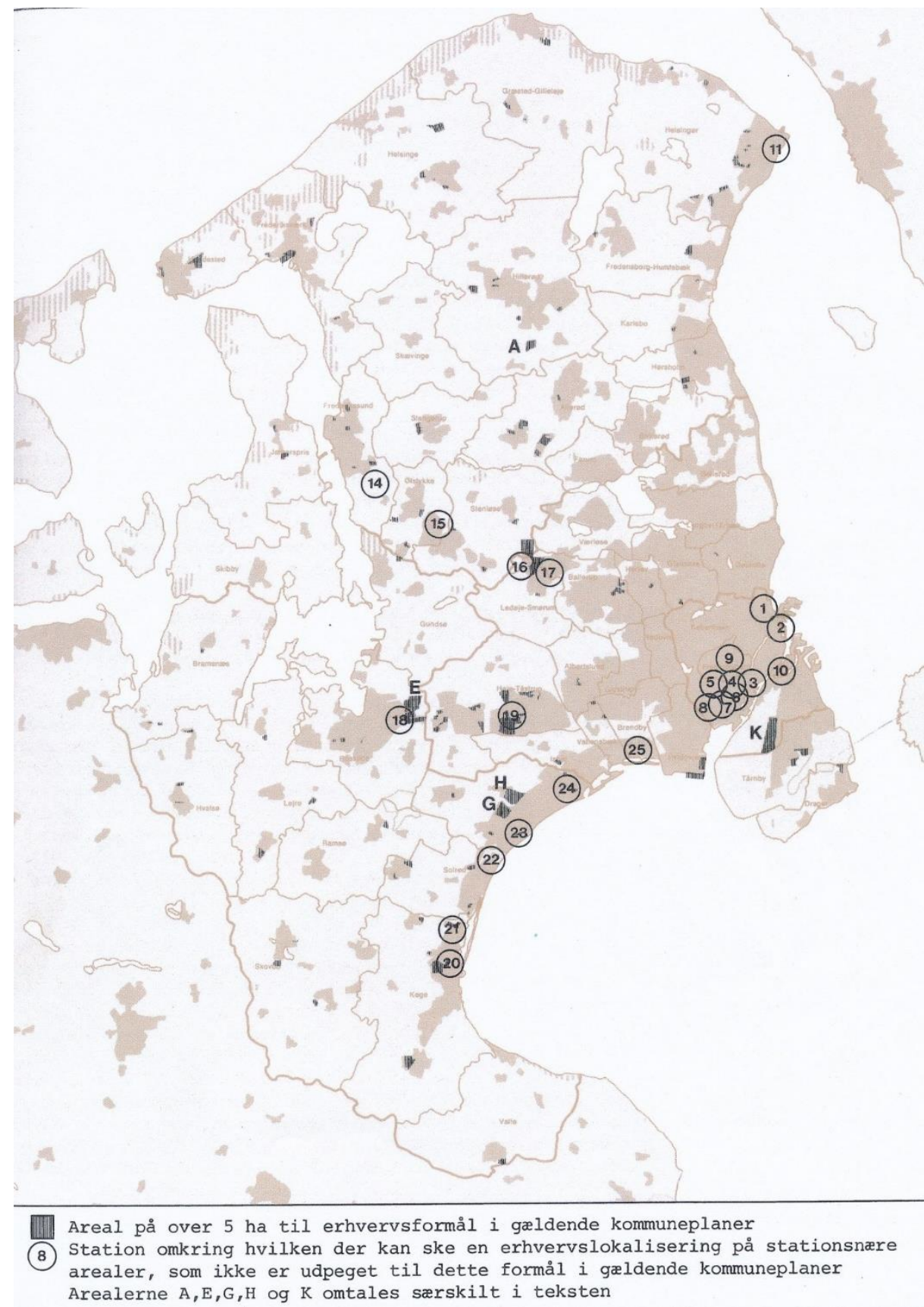

Også de nye erhvervsområder i Regionsplan 1989 blev kraftigt beskåret i forhold til Regionsplan 1973 (Regionsplan 1989, Hovedstadsrådet 1989)

Første etapeplan og regionsplantillæg

Selv om den økonomiske krise og olieforsyningskrisen var slået i gennem, da Hovedstadsrådet overtog Regionsplan 1973, påvirkede disse ændrede vilkår og den begyndende stagnerende befolkningsudvikling i hovedstadsmetropolen ikke den tidsfølgeplan til regionsplanen, som rådet udarbejdede i 1975. Men tidsfølgeplanens opretholdelse af Regionsplan 1973s høje vækstforudsætninger gav anledning til et længere tovtrækkeri mellem Hovedstadsrådet og Miljøministeriet. Ministeriet måtte således forholde sig til et bredt landspolitisk ønske om en mere decentral urbanisering og en udjævning af de regionale forskelle mellem byerne og ØstVestdanmark. Et ønske, der også afspejledes i de regionsplanforslag, der begyndte at komme ind fra amtskommunerne ud i landet, og som ud fra den såkaldte servicecenterteori gav mellemstore og mindre byer roller som regionale og lokale vækstskabende servicecentre. 
Servicecentre, der stod i skarp kontrast til den yderligere vækst i hovedstadsmetropolen, og i øvrigt også i Ârhus-metropolen, som Hovedstadsrådet gennem sin regionsplanlægning selvsagt måtte skabte de bedste betingelser for.

I tovtrækkeriet med Miljøministeriet og den bagvedliggende Planstyrelse måtte Hovedstadsrådet dog trække sig gang på gang op gennem den sidste del af 70 'erne og ind i det nye årti. Selv om den Første Etapeplan 1977-1992, som Hovedstadsrådet fik endeligt godkendt i 1979, og regionsplantillæggene op gennem 80 'erne, som tillige omfattede de rummelige aspekter af samtlige af Hovedstadsrådets meget omfattende sektorplaner, fastholdt hovedstrukturen fra Regionsplan 1973 og dermed dens vækstbaserede planpræmisser, blev omfanget af byvækstområder for erhvervs- og boligområder og lokaliseringsretningslinjerne herfor $\mathrm{i}$ de overordnede planrammer af flere omgange barberet $\mathrm{i}$ et sådant omfang, at hele grundlaget bag Regionsplan 1973 fortonede sig for til sidst helt at udgå i Hovedstadsrådets sidste regionsplan. ${ }^{26}$

\section{Regionsplan 1989}

Regionsplan 1989 brød dermed endelig med vækstcenterteorien, og blev bragt $\mathrm{i}$ overensstemmelse med tidens fortsatte økonomiske lavvækst og de endnu herskende landspolitiske prioriteringer af decentral urbanisering og en højere grad af udjævning af landets regionale forskelle. Samtidig vendte Regionsplan 1989 i udvidet form tilbage til det tankegods, der lå til grund for Fingerplanen fra 1948 og den første etapeplan fra 1963.

I form af en hovedstadsmetropol bestående dels af en sammenvokset enhed, omfattende selve hovedstaden og de ældre forstæder, der havde lagt sig uden om, og radiale forstadsbånd, der med deres hidtidige fordeling af bebyggelsesarter forlængedes til og integrerede med købstadsringens store købstæder, dels af de pendlersatellitbyer, der lå uden for denne såkaldte Fingerby. Et bylegeme og en ny hovedstruktur, der blev bundet sammen af forlængede radiale trafikforbindelser, og et udvidet lag af tværgående koncentriske kollektive trafiklinjer, ved hvis krydsning af radiallinjerne Regionsplan 1989 lagde op til dannelse af en række nye regionale knudepunkter. Punkter, der i vekslende omfang skulle rumme delregionale detailhandelsfunktioner og både produktions- og serviceproduktionsbaserede virksomheder. ${ }^{27}$

\section{Sektorplanlægning}

Ved opbygningen af det socialt sikrende og omfordelende velfærdssystem, gennemførelse af økonomisk vækststimulerende dispositioner så som tilvejebringelse af almene produktionsbetingelser, f.eks. trafik- og forsyningsanlæg, erhvervsstøtteordninger og økonomisk politik, samt forskellige former for samfundsreguleringer, havde den fremvoksende velfærdsstat op gennem det 20 . århundredes første halvdel betjent sig af en udbredt sektorstyring; jf. APPENDIX I.B. En styringsform kendetegnet af en stærk statslig detailstyring af, indseende med og indflydelse på konkrete kommunale dispositioner inden for velfærdsstatens aktionsfelt og i særlig grad ved behandling af enkeltsager, navnlig når der hertil knyttede sig statstilskud-, refusioner- eller- lån. Med det udvidede aktionsfelt, som den universalistiske velfærdsstat fik op gennem den første efterkrigstid, og det samtidige ønske om yderligere at udbygge både velfærdssystemet og statsformens vækststimulerende og regulerende instrumenter, kunne den statslige sektorstyring i længden ikke håndtere det offentliges stadig flere og mere forskelligartede dispositioner, der i stigende grad samtidig influerede på hinanden. Styring via planlægningsinstrumenter blev derfor stadig mere udbredt og et centralt styringselement i den ændrede opgavefordeling, som velfærdsstatens forvaltning fik med 1970-kommunalreformen.

\section{En ny styringsform}

Med 1970-kommunalreformen fik primærkommuner og amtskommuner en sådan størrelse og form, at hovedparten af velfærdsstatens hidtidige og nye konkrete opgaver kunne udlægges hertil, samtidig med at det kommunale niveau fik større dispositionsfrihed, og forvaltningen af statsformens velfærdssystem, reguleringer og øvrige dispositioner kom tættere på den befolkning og de 
virksomheder, som den var målrettet til. Udover landsopgaver som det overordnede trafiksystem, forsvar, politi, retsvæsen og videregående uddannelser m.m., blev det efter 1970-kommunalreformen i det væsentligste statens hovedopgave via lovudfyldning og-administration at sikre gennemførelsen af de landspolitisk vedtagne beslutninger og en hensigtsmæssig ressourceanvendelse i hele den offentlige sektor og at opnå indsigt i udviklingstendenserne inden for hele velfærdsstatens aktionsfelt med henblik på initiativtagning til og forberedelse af ny lovgivning.

Til denne centralstatslige opgavevaretagelse indskrænkedes den hidtidige sektorstyring til regelstyring gennem udsendelse af administrative rammebestemmelser for statslige institutioner, primær- og amtskommuner, i form af bekendtgørelser, cirkulærer, vejledninger m.m., og suppleredes med nye styringsredskaber i form af dels en økonomistyring via de generelle bloktilskuds- og refusionssystemer, der erstattede det store antal af forskellige refusions- og tilskudsordninger, der var etableret i takt med velfærdsstatens opbygning siden starten af århundredet, dels planstyring, eller sektorplanlægning, indenfor velfærdsstatens stadig mere udvidede samfundsmæssige aktionsfelt.

I sektorplanlægningen fastlagde statsmagten ud fra sektorvise landsplansskitser og-redegørelser og gennem konkrete bestemmelser og vejledninger, mål og retningslinjer for indholdet af de sektorplaner, som kommunerne og navnlig amtskommunerne skulle udarbejde inden for de sektorer, der var tillagt det kommunale niveau at varetage. Planforslagene skulle efterfølgende godkendes af de enkelte ressortministerier, hvortil der fra det kommunale niveau siden skulle fremsendes redegørelser for administrationen af og udviklingen inden for sektorplanområderne, således at disse redegørelser kunne danne grundlag for både de reviderede sektorplaner, som primær- og amtskommunerne med jævne mellemrum skulle udforme, og centraladministrationens initiativer til og forberedelse af ny eller justeret lovgivning.

For at udbygge det socialt sikrende og generelt omfordelende velfærdssystem for alle samfundslag og rent geografisk og for samtidig at opnà en bedre udnyttelse af de mere begrænsede økonomiske ressourcerammer, der lagdes for velfærdsstaten som følge af markedsøkonomiens tilbagevendende $ø$ konomiske kriser, gennemførtes op gennem den sidste efterkrigstid en lang række sektorplaner på det sociale, sundheds- og sygehusmæssige område samt på undervisnings-, kultur-, bolig- og arbejdsmarkedsområdet. Af hensyn til den økonomiske vækst, der var forudsætningen for velfærdsstaten og de almindelige forbedringer $\mathrm{i}$ indkomst- og levevilkårsforholdene, udarbejdedes på samme tid i stadig større omfang erhvervsmæssige og økonomiske sektorplaner for så vidt trafik-, forsynings- og energisektoren og økonomisk udvikling og politik. Som følge af den nære sammenhæng mellem de nye forsynings-, miljø- og energipolitikområders forsøg på at opnå en mere samfundsmæssig rationel udnyttelse af eksisterende og nye energiformer, der yderligere aktualiseredes af periodens økonomiske kriser og olieforsyningskriser og den miljøindsats, som samtidig indledtes for at modvirke den forurening, der allerede var fulgt og yderligere ville følge af industri, urbanisering, den teknologiske udvikling og privatforbruget, gennemførtes endvidere sektorplanlægning for så vidt varme- og energiforsyning, vandindvinding, råstofudnyttelse, beskyttelse af landbrugsarealer, fredning, det åbne land, spildevand m.m.

Da stort set alle dele af velfærdsstatens aktionsfelt i de sidste efterkrigsårtier således blev indspundet i en stadig mere omfattende sektorplanlægning, der dels blev stadig mere integreret, og hvis enkelte dele blev stadig mere sammenhængende og gensidigt afhængige, dels havde en fysisk dimension i form af arealanvendelse, regulering af bebyggelse og udnyttelse af det åbne land og dets ressourcer, blev den overordnede samfundsmæssige helhedskoordinering og-prioritering af sektorplanlægningens $\varnothing$ konomisk-administrative del overladt til centraladministrationen, mens den konkrete og regionale sektorplanlægning blev en amtskommunal opgave, hvor sektorplanernes fysiske og rummelige dimensioner skulle opsamles og indskrives i regionsplanlægningen. ${ }^{28}$

\section{Regionalt i hovedstadsmetropolen}

Da Hovedstadsrådet allerede fra oprettelsen i 1974 og siden i stigende grad i de efterfølgende 15 àr fik tillagt størsteparten af de sektorplanopgaver med ledsagende administrative og tilsynsmæssige funktioner, der udenfor hovedstadsmetropolen tillagdes amtskommunerne rundt om i landet, skulle 
denne planlægnings rummelige dimensioner efter metropolens særlige regionsplanlov og de forskellige sektorplanlove indpasses i de overordnede regionsplanmæssige planrammer for metropolen og indskrives som planretningslinjer i regionsplantillæg.

Samtidig med udarbejdelsen af den tidfølgeplan og konkretisering af de overordnede planrammer, der udgjorde Første Etageplanen 1977-1992, havde Hovedstadsrådets forvaltning påbegyndt arbejdet med de sektorplanområder, som indgik i rådets portefølje. Et arbejde, der forstærkedes efter, at Miljøministeriet i 1979 havde godkendt etapeplanen, og i den forbindelse som en forudsætning herfor havde krævet, at sektorplanlægningens fysiske aspekt kom til at indgå i efterfølgende regionsplantillæg. Blandt Hovedstadsrådet sektorplanområder indgik helt centralt den samlede trafikplanlægningen i hele hovedstadsmetropolen, hvor rådet samtidig fik ansvaret for driften af den kollektive trafik gennem dets Hovedstadsområdets Trafikselskab (HT). Hertil kom sektorplanopgaver for så vidt hovedstadsmetropolens elforsyning, vandindvinding og- forsyning, energi- og

varmeforsyning, sygehusområde, spildevandsafdeling og andre miljømæssige forhold. Som et centralt sektorplanområde blev tillige regional planlægning og anvendelsesregulering af hovedstadsmetropolens åbne land. Et sektorplanområde, der fik afgørende betydning for den regionsudfordring, som sommerhusbysspredningen udgjorde. ${ }^{29}$ 


\section{Sommerhusbyerne i regionssektorplanlægningen}

Med den betydelige udbredelse af sommerhusbyer i hovedstadsmetropolens ydre åbne land op gennem den første efterkrigstid og det forsatte om end mere beherskede sommerhusbyggeri i de sidste efterkrigstidsårtier, kom disse bydannelser, deres videre udbredelse og de øvrige regionale udfordringer, som de tillige bidrog med, til at indgå i Hovedstadsrådets sektorplanlægning på flere centrale områder.

\section{Regional planlægning af det åbne land}

Ligesom sommerhusbysspredningen blev en del af de regionsudfordringer i hovedstadsmetropolens åbne land, som alene fredningsplaner og konkrete fredninger og arealerhvervelser i den første efterkrigstid, og særlig i 60 'erne, forsøgte at imødegå, kom denne form for byspredning i den sidste efterkrigstid tillige til at indgå i Hovedstadsrådets sektorplanlægning af anvendelsen af metropolens ubebyggede og åbne yderområder.

\section{Forudsætninger}

Forsætningerne for Hovedstadsrådets sektorplanlægning for det åbne land og sommerhusbyernes placering heri, hvilede på den op til 1970-kommunalreformen i 1969 gennemførte ændring af naturfredningsloven og en del af de regionsplanmæssige forarbejder, der fulgte i forlængelse heraf.

\section{Lovbeføjelser}

Med de mange tillæg til 1937-naturfredningsloven og urbaniseringens fortsatte forstyrrelse i det åbne land både $\mathrm{i}$ hovedstadsmetropolen og i resten af landet nedsatte regeringen allerede $\mathrm{i}$ 1961 en naturfredningskommission, der i 1967 barslede med en omfattende betænkning. ${ }^{30}$ På grundlag af denne og tilpasset de forandrede opgavefordeling efter 1970-kommunalreformen gennemførtes i 69 en ændring af naturfredningsloven, der bl.a. indrømmede almenheden adgang til privatejede skove og uopdyrkede arealer og ret til badning og ophold ved samtlige af landets strande; offentlige som private.

Fredningsplanudvalgenes opgaveportefølje udvides ved lovændringen samtidig midlertidigt, således at disse fremover kunne opstille bestemmelser om beskyttelse af det åbne land mod sommerhusbebyggelser, ændringer af søers og offentlige vandløbs forløb og tilstand, placering af landbrugsbygninger og områders råstofudnyttelse. ${ }^{31}$ En optakt til at planlægningen og forvaltningen af det åbne land skulle indgå de nye amtskommuners, og fra 1974 tillige Hovedstadsrådets, sektor- og regionsplanlægning. Med henblik på en senere overførelse af fredningsplanlægningen til denne sektor- og regionsplanlægning, skulle fredningsplanudvalgene med de særlige kompetencer, de havde opbygget i årenes løb, desuden udarbejde særlige landskabsanalyser. ${ }^{32}$

\section{Centralstatslige pejlemærker}

En sektor- og regionsplanlægning af det åbne lands anvendelse, som den socialdemokratiske regering i 1972 lagde nogle overordnede pejlemærker for allerede inden, det lovforberedende arbejde i forbindelse med landsplanlægningen, den amtskommunale regionsplanlægning og den særlige lovpakke bag det kommende Hovedstadsråd var afsluttet. Pejlemærker, der sammen med landskabsanalyserne fra fredningsplanudvalgene var nødvendige for, at den regionale planlægning i højere grad end den hidtidige naturfredningsplanlægning kunne sikre det åbne lands kultur- og naturværdier og benyttelse af hele befolkningen.

I den forbindelse understregedes, at regeringen sigtedes mod "at gennemføre en aktiv rekreativ politik og søge tilvejebragt alternativer til den traditionelle sommerhusbebyggelse langs landets kyster, hvor der snart ikke længere vil være mulighed for en fortsættelse af den 
hidtidige udvikling, og samtidig fremme etableringen af de såkaldte naturparker rundt om i landet". Regeringen ville i den forbindelse "søge den nødvendige hjemmel til erhvervelse for det offentlige af jord, som er hensigtsmæssigt beliggende for en udnyttelse til feriecentre, marianer, campingpladser, kolonihaver og anden rekreativ anvendelse også for endagsturister", og fortsatte: "en sådan erhvervelsespolitik vil have såvel et beskyttelsesmæssigt som et socialt sigte. Det vil herigennem være muligt at fremme former for fritids- og friluftsliv af mere bredt orienteret karakter, end det hidtil har været tilfældet". ${ }^{33}$

I dette øjemed fik regeringen samme år, ud over den såkaldte sommerhuslov, se nedenfor, gennemført lovgivning om erhvervelse af fast ejendom til fritidsformål, hvorved det offentlige, gennem forkøbsret og ekspropriationsbeføjelser, fik forbedrede muligheder for at erhverve større arealer til rekreative formål. For at sikre det økonomiske grundlag stillede lovgivningen desuden statsmidler til rådighed for erhvervelse af arealer til feriecentre, campingpladser, kolonihaver m.m. Midlerne kunne anvendes til direkte statslige lån til amtskommuners eller almennyttige selskabers $k ø b$ af arealer til dette formål.

Loven om erhvervelse af fast ejendom til fritidsformål udsprang af det lovforslag, som Socialdemokratiet havde fremlagt i forbindelse med revisionen af naturfredningsloven i 1969, men som den daværende kortvarige borgerlige VKR-regering var veget tilbage for af frygt for, at det offentliges mere vidtgående muligheder for at erhverve større arealer til rekreativ benyttelse, ville medføre, at almennyttige selskaber, som bl.a. arbejderbevægelsen Dansk Folkeferie, opkøbte grundarealer, som burde være til rådighed for private sommerhuse. En markant politisering af det åbne lands rekreative anvendelse og ikke mindst af de individuelle interesser, der knyttes til sommerhuse på den ene side, og på den anden de mere almene, som var forbundet med de til sommerhuse alternative ferie- og fritidsbosætningsformer.

Da der med lovgivningen om erhvervelse af fast ejendom til fritidsformål lå en opfyldelse af det ønske, som arbejderbevægelsen og Lejerklubben Danmark, senere Dansk Campingunion, allerede havde formuleret i 30 'erne, blev den da også af det socialdemokratiske regeringsbærende parti set som et væsentligt element i den videre udvikling af velfærdsstatens kultur- og fritidssøjle. Det understregedes således, at selve loven og det samlede perspektiv i naturfredningslovgivningen var udtryk for en aktiv rekreativ politik med det sociale sigte at give de brede samfundslag rammer for et reelt fritids- og friluftsliv, hvor kolonihaven, campingpladsen og feriecentret var et alternativ til det sommerhus, som ikke alle kunne opnå. Et element, der kom til at indgå i de statslige pejlemærker for det ǻbne lands anvendelse og dermed også i amtskommunernes og Hovedstadsrådets kommende sektor- og regionsplanlægningen af samme og den dertil hørende særlige regionale sommerhusplanlægning; se nedenfor. ${ }^{34}$

\section{Regionsplanmæssige forarbejder}

Modsætningen mellem velfærdsstatens almene kultur- og fritidspolitiske interesser i det åbne land, der havde rødder tilbage til mellemkrigstiden, og individuelle interesser i forhold til friluftslivet, som bl.a. kom til udtryk ved sommerhusbesiddelse, blev konkretiseret i de regionsplanmæssige forarbejder op til Hovedstadsrådets varetagelse af de nye sektor- og regionsplanområder i form af en idéskitse fra hovedstadsmetropolens fredningsplanudvalg og Regionsplan 1973.

De landskabsanalyserne, som fredningsplanudvalget skulle udføre efter ændringerne i naturfredningsloven fra 1969 mundede således i 1973 ud i en idéskitse, der byggede på to systemer af sammenhængende landskabs- og naturområder. Dels den såkaldte "Regionalpark". Det helt tilbage fra Principskitsen i 1960 velkendte ydre grønne halvcirkulære bælte, der udgik fra Nordsjællands store sø- og skovområder, gik gennem hele Hornsherred og fortsatte videre ned over det midtsjællandske skovområdefor for derfra at løbe i retning mod Nordstevns. Dels de såkaldte "Egnsparker", der ville fuldende forslagene fra Den grønne Betænkning fra 1936, og tillige omfattede et grønt rekreativt bælte, der løb udenfor, gennem og ind $\mathrm{i}$ kilerne mellem de radiale forstadsbånd helt fra 
nordforstædernes skov- og søområder og ned mod Køge Bugt og med videre forbindelse til Vestamager. Idéskitsen forholdt sig ikke til hverken til eksisterende eller kommende sommerhusbydannelse, men at dens meget store arealudlæg for almenhedens friluftsliv ville få signifikant betydning for disse bydannelser, var indlysende.
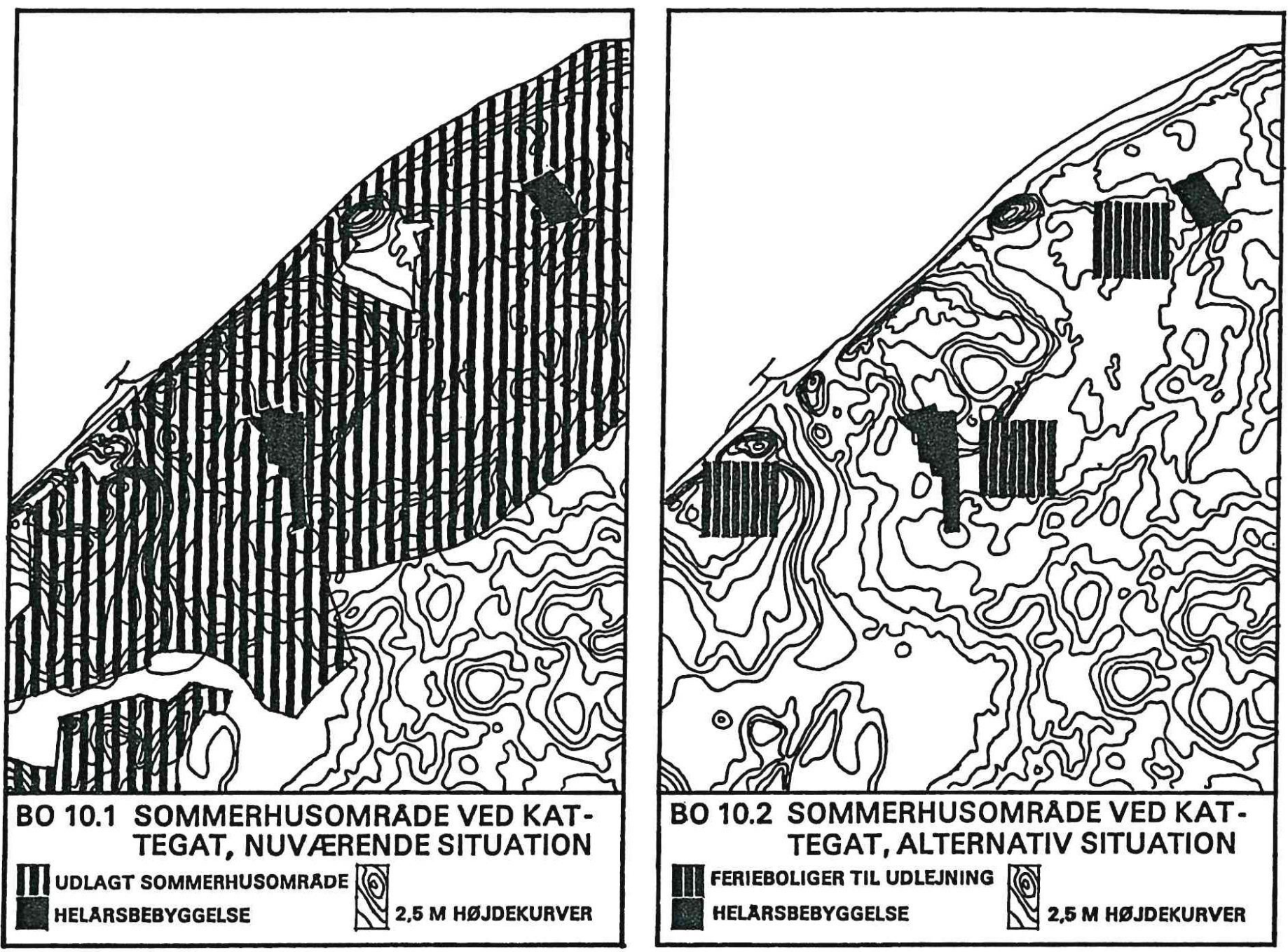

Del af sommerhusbybæltet ved Kattegatkysten. Til venstre: Den aktuelle bebyggelse i 1970. Til højre: Egnsplanrådets estimat af det abne areal, der samme sted ville have været til rådighed for almenhedens rekreative friluftsliv $i$ fald omradet havde haft en mere arealintensiv fritidsboligbebyggelse i form af udlejede ferieboliger: Campingpladser, feriebyer-og centre, hytter, kolonihaver m.m. Modsætningen mellem den individuelt baserede sommerhusby, som særlig ved Kattegatkysten antog groteske former, og en mere kollektiv og solidarisk løsning, der tog hensyn til almenhedens rekreative behov var entydig (Regionsplanlægning 1970-1985. Forudsætninger, 1971)

I Regionsplan 1973, der fremlagedes i 1974 og var afstemt med fredningsplanudvalget idéskitse, opereredes med tre former for rekreative områder i hovedstadsmetropolen, der skulle bevares, gøres tilgængelig for metropolbefolkningen, og dermed friholdes fra bymæssig vækst. Områderne omfattede bolignære friluftsarealer på $50 \mathrm{~m}^{2}$ pr. indbygger i gå- og cykelafstand fra boligområderne og daglige regionale fritidslandskaber på $200 \mathrm{~m}^{2}$ pr. indbygger i form af skove, åbent land, søer og åløb og med transportafstand til områderne på $15-20 \mathrm{~km}$. Herudover uden for de to byvækstområder meget store regionale udflugtsområder, der med transportafstande på 50-100 km og med kontakt til kyst- og søområder med mulighed for badning, lystfiskeri og sejlsport omfattede en betydelig del af Sjælland. Inspireret af den regionalpark, der indgik i fredningsplanudvalgets idéskitse, lagde Regionsplan 1973 op til, at det nordlige Nordsjælland, Hornsherred og det sydøstgående skov- og landskabsområde inden for hovedstadsmetropolens eget område skulle indgå i de vidtstrakte regionale udflugtsområder. 


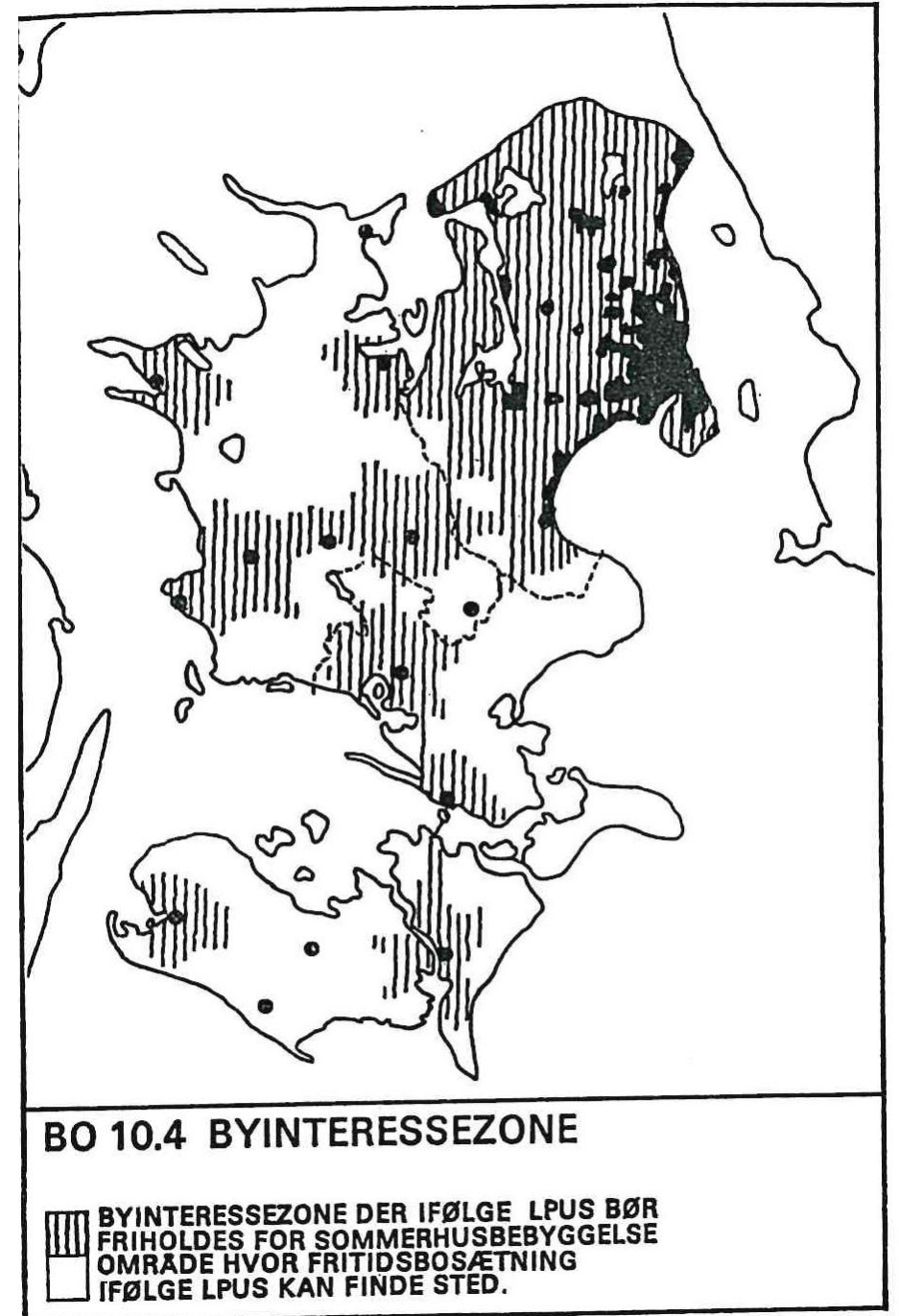

Egnsplanrådets byinteresseområder, hvor kommende sommerhusbyer skulle være udelukket og områder, hvor disse kunne udlægges (Regionsplanlægning 1970-1985. Forudsætninger, 1971)

Mens de bolignære friluftsområder primært skulle indarbejdes i de enkelte kommuneplaner, pegede Regionsplan 1973 for så vidt de daglige regionale fritidsområder på en fastholdelse af kilerne mellem forstæderne, etablering af tværgående grønne bælter mellem disse, gennemførelse af planerne for en strandpark ved Køge Bugt samt en rekreativ anvendelse af både Kalvebod Fælled samt Hedeland syd for Hedehusene. For at skabe sammenhæng mellem disse indre rekreative områder, de mellemliggende nye byområder og de store ydre regionale udflugtsområder, lagde Regionsplan 1973 endelig op tre grønne A-zoner, hvor gennemgående landskabsforløb kunne passerer fra skov- og søområderne vest for Farum i retning mod Arresø, fra den såkaldte Vestskovkilen, gennem Værebroådalen og til Roskilde Fjord og fra Vallensbækkilen og til grusgravsområderne sydvest for Hedehusene. For at opnå denne helhed skulle de resterende åbne landskaber frem mod kystområder ved Roskilde Fjords østside friholdes for yderligere bebyggelse. Herudover opperedes med senere rekreative A-zoner ved Holbæk-motorvejen ved roden af Hornsherred-halvøen, ved Vestmotorvejen vest for Køge samt ved på Sydmotorvejen syd for Køge for at skabe sammenhæng mellem de rekreative udflugtsområder i Hornsherred og dem, der i store skovområder lå sydøst herfor.

I de baggrundsanalyserende og- redegørende bind, som Egnsplansrådet fremlagde før Regionsplan 1973, og som dannede forudsætningen for denne, havde rădet slået fast, at hovedstadsmetropolens fremtidige sommerhusbydannelser, ville få et sådan volumen, at de ikke ville kunne rummes ind for metropolens åbne land, som følge af den allerede meget voldsomme sommerhusbysspredning, og 
følgelig måtte fordeles over ikke blot hele Sjælland, men også i det meste af Skåne. ${ }^{35}$ Rådet havde på det grundlag vurderet, at sommerhusbyplanlægningen nærmere skulle forhandles med Storstrøms og Vestsjællands amtskommuner og Nord- og Sydvästra Skånes Kommunalförbund. Forhold, der begrundede, at Regionsplan 1973 alene kom til at berøre den egentlige regionale byvækst og fordeling bebyggelsesarter med dertil hørende rekreative områder og ikke indeholdt nærmere retningslinjer for sommerhusbyernes fremtidige afgræsning og lokalisering.

Ikke desto mindre gjorde Egnsplanrådet sig en række overvejelser for perspektivet for den forventede sommerhusbysspredning og de regionale plandispositioner, der måtte træffes indtil, der var kommet en nærmere afklaring ved forhandlingerne med naboregionerne om den interregionale koordinerede planlægning af denne form for byspredning. Med sommerhusbyernes meget store arealkrav til huse og haveanlæg og relativt begrænsede benyttelse i weekends- og ferieperioder af enkeltfamilier, var sommerhuse udtryk for en meget ekstensiv både fritidsbosættelseform og arealudnyttelse til rekreative friluftsformål i forhold til andre fritidsbosætningsformer så som almennyttige campingpladser og feriebyer.

Endnu mere problematisk var det for Egnsplanrådet, at de hidtidige sommerhusbydannelser udgjorde "en alvorlig konflikt, idet et mindretal af husstande (ca. 10 procent i 1970) søger en del af deres fritidsbehov udfyldt gennem anskaffelse af eget sommerhus i attraktive landskaber ved skov og strand, hvorved det store flertals (ca. 90 procent) adgang til disse landskaber umuliggøres. Derfor forøger hver ny sommerhusudstykning i regionen konflikten med behovet for regionale udflugtslandskaber". ${ }^{36}$ Med forventede 100.000 nye sommerhuse i eksisterende og ekspanderende eller nyudlagte sommerhusbyer, ville denne konflikt mellem det individuelle og almene friluftsliv blive voldsomt forstærket, idet sommerhusbyerne ville lægge beslag på et areal, der svarede til hovedstadsmetropolens allerede bebyggede område.

For at imødegå denne kritiske udvikling lagde Egnsplanrådet i forhold til Hovedstadsrådets kommende videre regionsplanlægning op til, at der gennemførtes et stop for udlæg af nye sommerhusbyer i såkaldte byintesseområder for planlagt byspredning og rekreative arealudlæg, der omfattede ikke blot næsten hele hovedstadsmetropolen, men efter forhandling med Vestsjællands og Storstrøms amtskommuner også betydelige områder omkring Kalundborg, Holbæk, Vordingborg, Næstved, Nykøbing F, Nakskov og et bredt bælte langs strækningen mellem Roskilde-Ringsted-Sorø-SlagelseKorsør, hvorved alene det mellemste Lolland, dele af Falster, Møn, Bogø, Stevns, det indre Øst-, Sydvest-, Sydøst- og Nordvestsjælland og Odsherred kunne inddrages til videre sommerhusbyspredning. For at lede behovet for fritidsbosætning væk for sommerhusformen foreslog Egnsplanrådet, at den videre regionsplanlægning skulle indtænkte mere arealintensive eller helst til sommerhuset alternative fritidsbosætningsformer. Ikke blot ved udlæg af betydelige arealer til campingpladser og feriebyer, men også til kolonihaver, feriecentre, hoteller, pensionater, hytteudlejning og havneanlæg for lystbåde. Herudover skulle der ikke gives tilladelse til sommerhusbyers overgang til helårsbeboelse, som følge af de lokalkommunale udfordringer, der ville opstå i kølvandet heraf, og for at hindre at behovet for udlæg af yderligere sommerhusbyer, dermed forstærkedes. ${ }^{37}$

\section{Det åbne lands anvendelse}

Selv om rekreative og naturbeskyttende dispositioner havde udgjort den eneste regionale planlægningsform i det åbne land siden 30 'erne, og tillige kom til at stå centralt băde i Regionplan 1973 og Hovedstadsrådets regionale sektorplanlægning af anvendelse af de åbne og udbyggede landskaber, fik rådet op gennem den sidste efterkrigstid yderlige og andre sektorplanmæssige beføjelser i samme dele af hovedstadsmetropolen. Med det resultat, at der i perioden gennemførtes en samlet og integreret regional sektorplanlægning af det åbne land, der i henseende til dets rekreative, erhvervs- og bebyggelsesmæssige anvendelse, kunne indskrives i den samlede regionsplanlægning. 
Regionale rekreative og værdifulde naturområder

På grundlag af Regionplan 1973 og det forudgående regionplanarbejde gav Første Etapeplanen fra 1978, trods de i forhold til selve regionsplanen nedjusterede overordnede planrammer og- mål, en række mere detaljerede bindende retningslinjer for, hvorledes primærkommunerne skulle planlægge erhvervs- og boligområder ud fra de overordnede planrammer og heri samtidig indpasse det system af rekreative udlæg, som indgik i Regionsplan 1973. For det åbne land krævede etapeplanen, at kommunerne fasthold eksisterende byzoner omkring disse områders spredte landsbybebyggelser, bevarede værdifulde landskaber, skabte større almen adgang til disse, opretholdt et aktivt landbrug og afpassede lokale stisystemer i forhold til regionale. Herudover gav Første Etapeplanen kommunerne konkret anvisning på, hvorledes disse skulle indpasse de lokale dispositioner i det åbne land i forhold til Regionplan 1973s mere løselige geografiske angivelser af bolignære friluftsarealer, daglige regionale fritidslandskaber, gennemgående landskaber mellem disse og de regionale udflugtsområder, hvis sammenhæng desuden skulle sikres. ${ }^{38}$

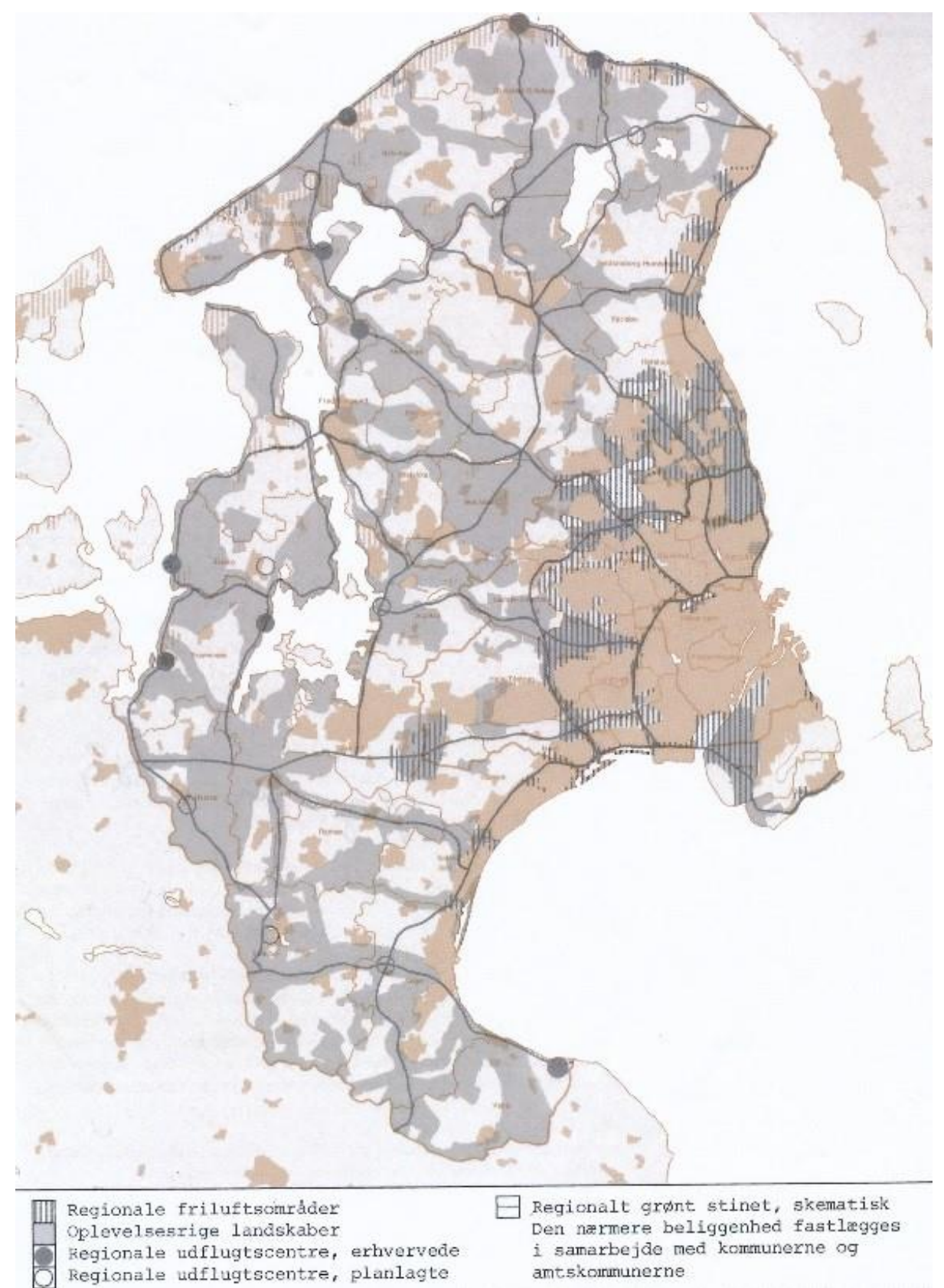

Hovedstadsmetropolens friluftsområder efter Regionsplan 1989 (Regionsplan 1989, Hovedstadsrådet 1989) 
I medfør af en ændring i naturfredningslovgivningen overtog Hovedstadsrådet, i lighed med amtskommunerne i der øvrige land, i 1978 fredningsplanlægningsopgaven fra de statslige fredningsplanudvalg, der samtidig nedlagdes. ${ }^{39}$ I tilknytning til lovændringen etableredes den lovforeskrevne særlige fredningsadministration, der udarbejdede de fredningsplaner, som efterfølgende blev indskrevet i regionsplantillæggene og i øvrigt traf afgørelser på de områder, der efter naturfredningsloven var tillagt Hovedstadsrådet. Udover selve fredningsplanlægningen, blev rådet den besluttende myndighed for så vidt vej- og forsyningsanlæg i det åbne land, sager vedrørende hegning og ændring af vådområder, og kunne rejse fredningssager for fredningsnævnene, ligesom rådet ydede nævnene og overfredningsnævnet bistand for så vidt fredningssager og sager om dispensation fra fredning og bygge- og beskyttelseslinjer. Herudover skulle Hovedstadsrådet føre tilsyn med overholdelse af fredningskendelser, naturfredningslovens bestemmelser og plejeforpligtigelser for så vidt fortidsminder.

Med denne meget brede opgaveportefølje udarbejdede rådsforvaltningen i 1981 med udgangspunkt i såvel Regionsplan 1973 som Første Etapeplanen primærkommunale planlægningsretningslinjer gennem en række planlægningsdokumenter med redegørelser for det åbne land og med forslag til udpegning af såkaldte fredningsplaninteresseområder. Dokumenter, hvis regionsplanmæssige retningslinjer, der efterfølgende blev indskrevet i 80 'ernes regionsplanstillæg, omfattede fredningsinteresseområder af landskabelig, kulturhistorisk og biologisk værdi, som skulle udmøntes i Hovedstadsrådets videre fredningsplanlægning, og hvis sikring og videre pleje skulle indarbejdes i kommunernes kommune- og lokalplaner. Uden væsentlige ændringer blev disse fredningsinteresseområder indskrevet i Hovedstadsrådets endelige Regionsplan 1989, der blev godkendt af Miljøministeriet, lige før rådet lukkede ned ved udgangen af samme àr.

Ud fra disse fredningsinteresseområder kunne 80'ernes regionsplantillæg og Regionsplan 1989 endeligt geografisk afgrænse og opstille planmæssige retningslinjer for områder af signifikant betydning for metropolbefolkningens friluftsliv. Retningslinjer, der blev bestemmende for, hvordan kommunerne via kommune- og lokalplaner, stianlæg, træplantning og andre dispositioner ikke blot skulle sikre områderne til friluftsformål, men også give dem de forskellige rekreative anvendelsesmuligheder alt efter de funktioner, som fredningsinteresseområderne tillagdes.

80 'ernes regionsplanstillæg opdelte således hovedstadsmetropolens rekreative fredningsinteresseområder i: Dels de såkaldte kileområder i fingerbyområdet, altså nordforstædernes store skov- og søområder og de grønne kiler mellem forstadsbåndene, som Regionsplan 1973 havde betegnet som "daglige regionale fritidslandskaber". Dels, som en nydannelse bynære friluftsområder med stianlæg og tilgængelige friarealer omkring købstæderne og de uden for liggende satellitbyer. Dels regionale udflugtsområder i form af såvel hedelandet mellem den ydre del af Køge Bugts og Vestbanens forstadsbånd, hvor de rekreative muligheder af hensyn til disse egnens behov for friluftsområder skulle forbedres via skovplantning, terrænformning og friluftsanlæg, som Mølleådalen vest for Farum Sø, hvor regionsplantillæggene af hensyn til områdets sårbarhed ikke anbefalede yderligere rekreative anlæg.

Ude i de ydre dele af hovedstadsmetropolen, som udgjorde fredningsinteresseområder af kulturhistoriske, landskabelige og biologiske værdier og fortrinsvis de områder, som Regionsplan 1973 i sin tid havde betegnet som "regionale udflugtsområder", udlagdes endelig en række regionale udflugtscentre med overnatningsfaciliteter. Herudover reserveredes de gennemgående landskabsskabsforløb mellem de indre rekreative områder og de øvrige regionale udflugtsområder i det nordlige Nordsjælland, ved Roskilde Fjord, i Hornsherred og i de sydøst for liggende skov- og naturområder. 


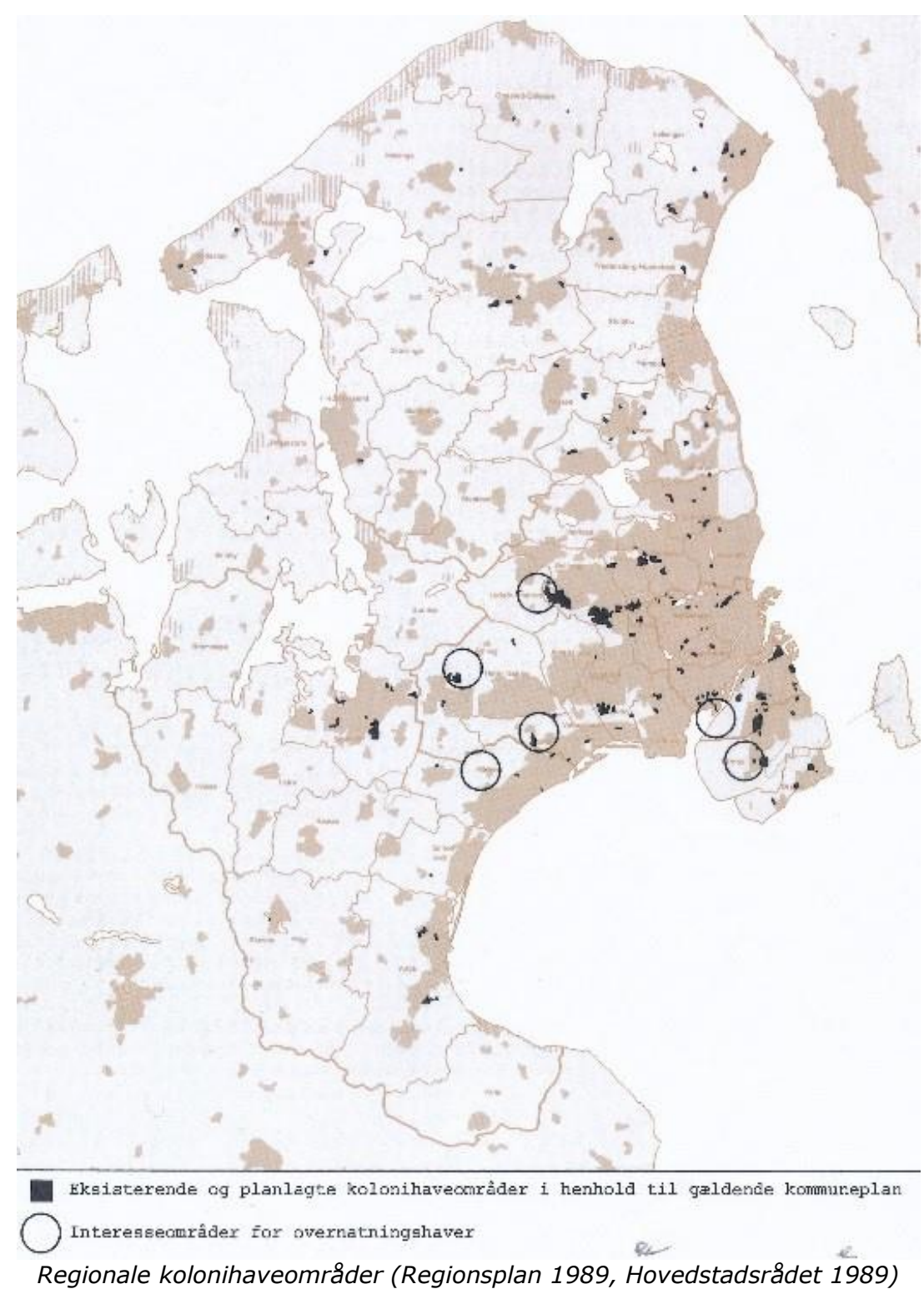

Selv om Regionsplan 1989 ophævede regionsplantillæggenes hidtidige opdeling af hovedstadsmetropolens rekreative områder, gik de alligevel igen i denne regionsplans retningslinjer for kommunernes stedlige kommuneplanlægning og den fredningsplanlægning, som de to hovedstadskommuner og de tre hovedstadsamtskommuner skulle kaste sig ud $\mathrm{i}$ efter Hovedstadsrådets nedlæggelse i 1990. I Regionsplans 1989 's såkaldte regionale friluftsområder kom således den indre hovedstadsmetropols grønne kileområde til at indgå sammen med de områder, der i regionsplantillæggene var udlagt til regionale friluftsområder ved siden af særlige kystkiler, der langs kysterne ved Køge Bugt, Øresund og Kattegat mellem bebyggelser skulle skabe såvel en naturlig sammenhæng mellem kyst og bagland som direkte offentlig adgang til kystlinjen. Den øvrige del af hovedstadsmetropolens fredningsinteresseområder blev, uden for de regionale friluftsområder, i Regionsplan 1989 udlagt som såkaldte oplevelsesrige landskaber med såkaldte regionale udflugtsmål med henblik på varierede friluftsoplevelser ud fra biologiske, landskabelige eller kulturhistoriske interesser. Landskaberne skulle således ikke blot varetage rekreative behov, men tillagdes også kulturelt højnende værdi, og fik dermed samme velfærdspolitiske betydning, som da planerne om rekreativ regional naturadgang blev udtænkt i 30 'erne. 
De oplevelsesrige landskaber, der omfattede det nordligste Nordsjælland, Mølleådalen med omgivende landskaber, det meste af Hornsherred og områderne derfra i sydøstlig retning mod Køge, skulle som i regionsplantillæggene således også i Regionsplan 1989 omfatte en række regionale udflugtscentre, som ud over overnatningsfaciliteter nu skulle udrustes med naturskoler og skiltning, der gav anvisning på brugen af de omliggende naturområder. Som tilsvarende arvegods fra mellemkrigstidens rekreative regionale plantænkning, lagde Regionsplan 1989 endelig op til en række grønne stier, der skulle forbinde både den fingerby, som var den nye hovedstruktur i regionsplanen, og de uden for liggende satellitbyer med de oplevelsesrige landskaber og disse landskaber indbyrdes. Det grønne stinet skulle så vidt muligt desuden passere de radiale banelinjer, således at der herfra kunne opnås let adgang til landskaberne.

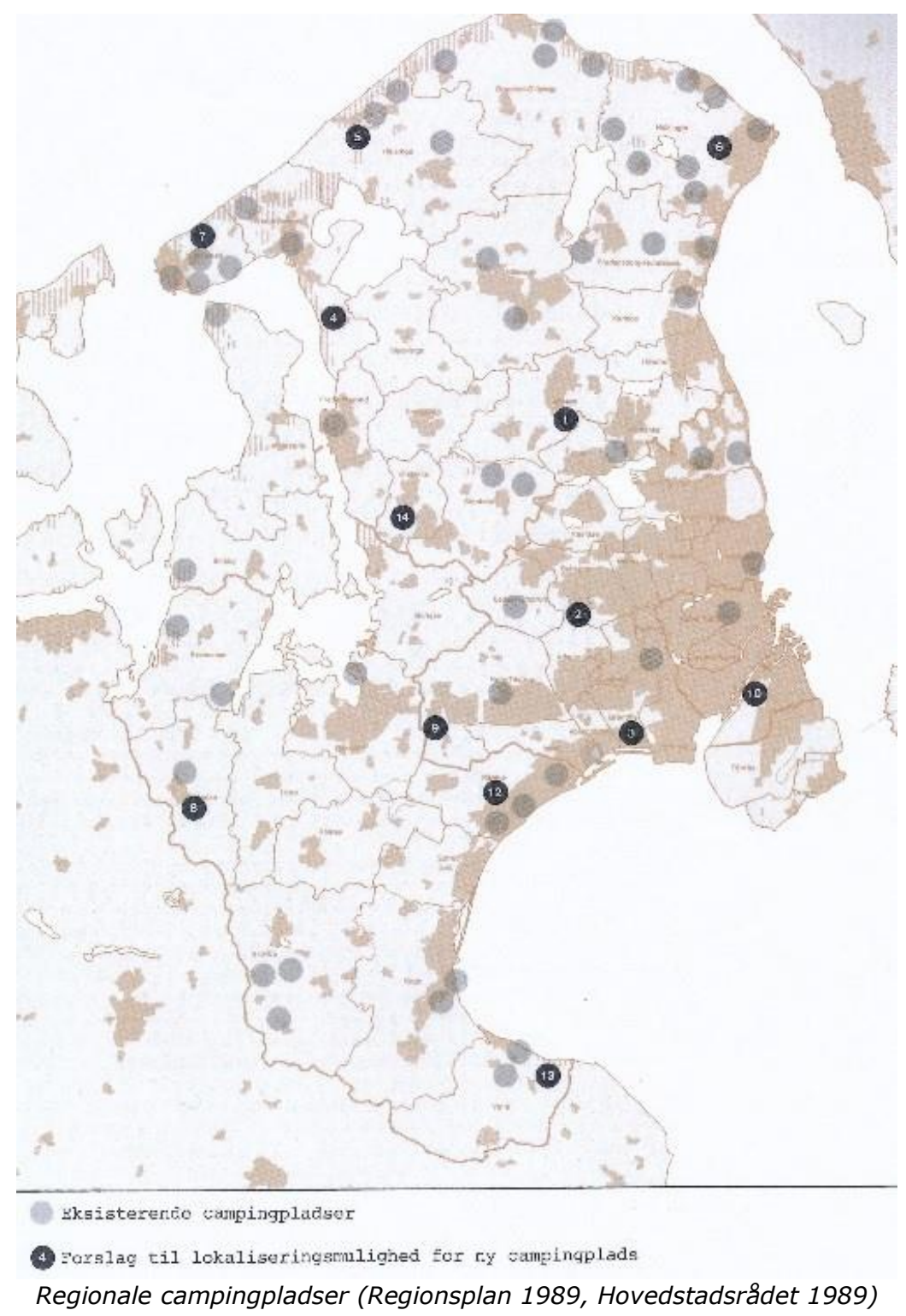

Den rekreative planindsats

Da de dele af fredningsplanen og fredningsplanforsalgene fra 60 'erne, der ikke var blevet gennemført før nedlæggelsen af fredningsplanudvalget i 1978, overførtes til Hovedstadsrådets sektor- og regionsplanlægning for det åbne land, og da denne planlægning, som anført, udvidedes betragteligt, skabtes grundlaget for yderligere fredninger og andre rekreative arealerhvervelser og- dispositioner. 
Herved tilvejebragtes yderlige grønne kiler til og frialer ved Kattegatkysten på samme tid, som de stedlige kommuner på grundlag af Hovedstadsrådets planlægning udarbejdede lokalplaner, der sikrede tilsvarende arealer, værdifulde kyststrækningen og ældre karakteristiske bebyggelser. Hertil føjede sig sikringen af betydelige højklassede natur- og kulturhistoriske rekreative kyst- og landskabsområder syd for Køge, i Hvalsø, Slangerup, Lejre, Bramsnæs, Skibby og Jægerspris kommuner og i den nordligste og centrale del af Nordsjælland og dermed ude i de oplevelsesrige landskaber. Endelig gennemførtes yderligere fredninger i nordforstadskommunerne Søllerød, Birkerød, Farum og Hørsholm og af Kalvebodkilen på Amagers sydkyst. ${ }^{40}$

Tabel IV. 20. Fredede områders procentandel af det samlede areal i hovedstadsmetropolen og landets amtskommuner, 1917-1989

\begin{tabular}{|l|c|l|c|}
\hline Hovedstadsmetropolen & 8,8 & Ribe Amtskom. & 3,5 \\
\hline Vestsjællands Amtsk. & 4,1 & Veje Amtskom. & 4,3 \\
\hline Storstrøms Amtskom. & 3,2 & Ringkøbing Amtskom. & 3,7 \\
\hline Bornholms Amtskom. & 6,1 & Arhus Amtskom. & 4,5 \\
\hline Fyns Amtskom. & 1,6 & Viborg Amtskom. & 6,1 \\
\hline Sønderjyllands Amtskom. & 2,3 & Nordjyllands Amtskom. & 4,4 \\
\hline
\end{tabular}

Hele landet: 4,2 procent. Kilde: Statistisk Árbog 1990, s, 9.

Med det fredningsplanarbejde og de konkrete fredninger, som Hovedstadsrådet fik mulighed for at tage initiativ til i den korte årrække, hvor rådet fik lov at varetage denne opgave, og den fredningsindsats, der var gjort siden naturfredningslovens gennemførelse i 1917 og særlig i løbet af 60 'erne og den første del af det følgende årti, kom hovedstadsmetropolen i 1990 også i naturfredningsmæssig henseende til at indtage en særstilling i landet. Mens metropolen alene omfattede 7 procent af Danmarks samlede areal, udgjorde de fredninger, der her var gennemført siden 1917-naturfredningsloven og frem til 1990, 14 procent af landets samlede naturfredningsbelagte område. ${ }^{41}$ Med et samtidigt fredet areal på næsten 9 procent af hovedstadsmetropolens samlede areal, mod et landsgennemsnit på 4,2 procent, kom metropolens således til at udgøre den del af landet, hvor velfærdsstatens naturbevarende og rekreative fredningsbestræbelser slog kvantitativt kraftigst igennem (tabel IV.20).

Mens de rekreative og naturbevarende interesse i hovedstadsmetropolens ydre åbne opland $\mathrm{i}$ efterkrigstid kunne opnås gennem disse fredninger eller via snævre inder- og byzoneudlæg omkring de stedlige rurale bebyggelser, sikredes de såkaldte kileområder i

hovedstadsmetropolens indre del op gennem det 20. århundredes sidste halvdel via et samvirke af en række forskellige virkemidler og af hovedstadsmetropolens regionalt agerende aktører: Staten, hovedstadskommunerne og-amtskommunerne, de enkelte stedlige kommuner og siden tillige Hovedstadsrådet. En indsats, der resulterede i, at der inden $1990 \mathrm{i}$ denne del af metropolen blev skabt et rekreativt sammenhængende system bestående af: Eksisterende skov- og søområder og hermed sammenhængende fredede områder, kunstigt anlagte naturområder samt grønne kiler og tværgående rekreative bælter. ${ }^{42}$

Tabel IV. 21. Rekreative og landbrugsmæssige arealers procentvise andel af hovedstadsmetropolens areal, 1990 , ha.

\begin{tabular}{|l|c|c|c|c|c|}
\hline & Hovedstaden & $\begin{array}{l}\text { Københavns } \\
\text { Amtskommune }\end{array}$ & $\begin{array}{l}\text { Frederiksborg } \\
\text { Amtskommune }\end{array}$ & $\begin{array}{l}\text { Roskilde Amts- } \\
\text { kommune }\end{array}$ & $\begin{array}{l}\text { Hovedstads- } \\
\text { metropolen }\end{array}$ \\
\hline Fritidsområder & 12,8 & 8,0 & 7,1 & 2,8 & 6,1 \\
\hline Skove & 0,0 & 11,5 & 15,8 & 10,3 & 12,7 \\
\hline Naturområder & 11,9 & 10,5 & 2,3 & 1,1 & 3,4 \\
\hline Vådområder & 4,1 & 4,9 & 6,2 & 1,1 & 4,3 \\
\hline $\begin{array}{l}\text { Rekreative områder. } \\
\text { Total }\end{array}$ & 28,8 & 34,9 & 31,4 & 15,3 & 26,5 \\
\hline Landbrug & 0,0 & 19,4 & 53,9 & 70,1 & 50,1 \\
\hline
\end{tabular}

Kilde: Statistisk Årbog for København, Frederiksberg m.m., 1990, 252

Samme med de oprindelige skov- og søområder og som et resultat af velfærdsstatens forskelligartede bestræbelser for gennem det 20. ărhundrede at skabe friluftsområder for hovedstadsmetropolens brede befolkning, kom det samlede rekreative areal i 1990 op på 26,5 
procent af metropolens samlede areal, fordelt med $6,1,12,7,3,4$ og 4,3 procent på henholdsvis fritidsområder, skove, udlagte naturområder og vădområder (tabel IV.21). Mest markant i de tætbebyggede indre forstadsområder i Københavns Amtskommune, hvor de store skov- og søområder i den nordlige del sammen med udlagte fritidsområder og rekreative naturområder lagede beslag på over en tredjedel af arealet, mens knapt halvdelen var bebygget med săvel det indre koncentriske forstadsbælte og de uden for liggende radiale forstadsbånd.

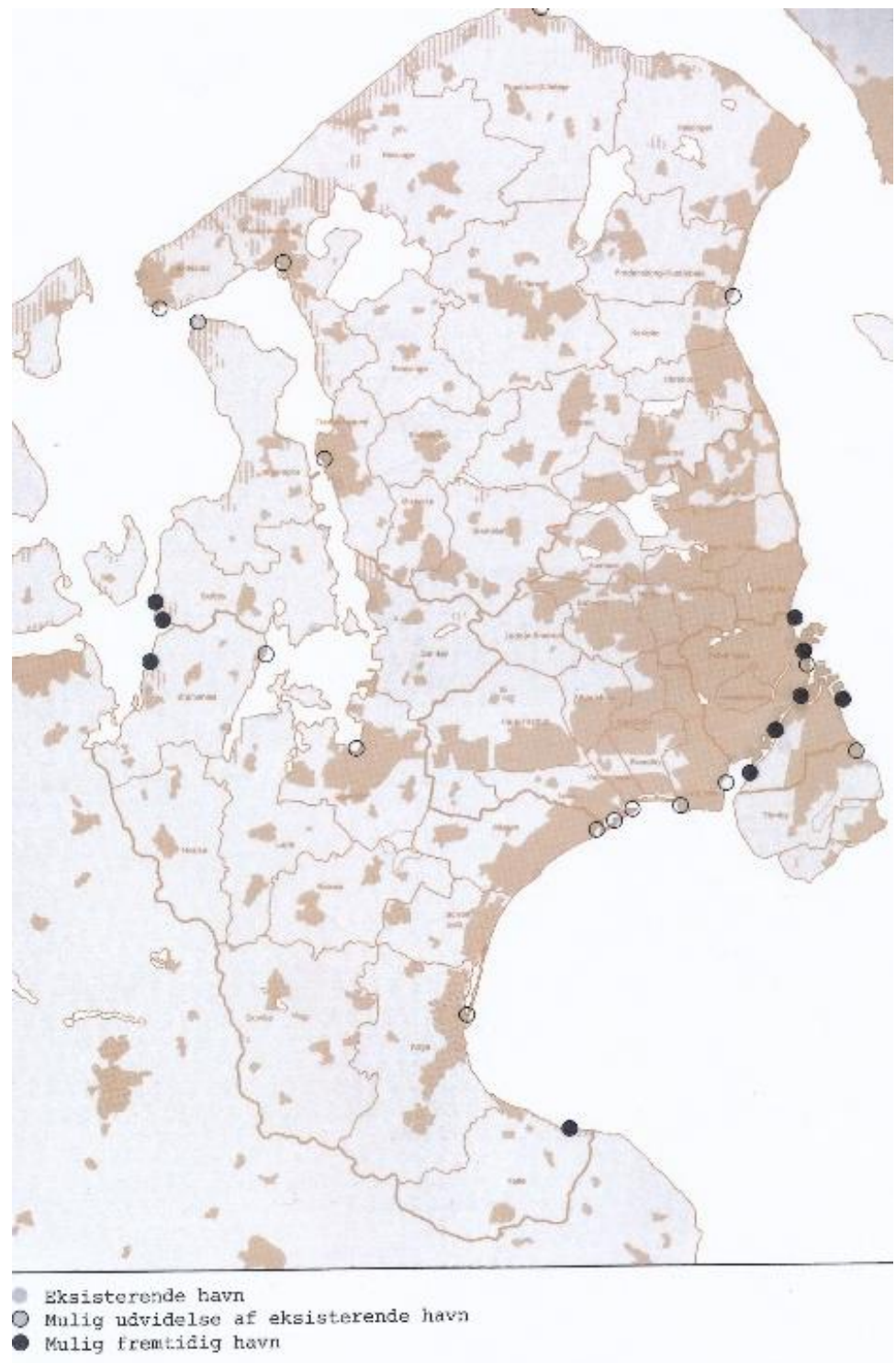

Lystb̊̊dehavne (Regionsplan 1989, Hovedstadsrådet 1989)

Selv om 15 procent af arealet i ydre hovedstadsamtskommuner var bebygget med de ydre dele af de radiale forstadsbånd, købstadsringens købstæder og pendlersatellitbyer omfattede de rekreative områder ikke mindre end knapt en tredjedel af Frederiksborg Amtskommunes areal. Nordsjællands meget omfattende skov- og søområder, var selvsagt medvirkende hertil, men oven i kom, at ca. ti procent her var udlagt til fritidsområder og rekreative naturområder. I hovedstadsmetropolen sydlige del i Roskilde Amtskommune udgjorde skov- og søområder ganske vist godt en tiendedel af arealet, men da alene fire procent her var udlagt til fritidsområder og rekreative naturområder, kom de rekreative områder her kun til at udgøre 15 procent af arealet. Til gengæld henlå ikke mindre end 70 procent af arealet som et opdyrket åbent landbrugsområde med de særlige kvaliteter, det indebar. 
Hovedstadsmetropolen center, selve hovedstaden, udgjorde for så vidt den rekreative arealanvendelse en særstilling. Selv om over 70 procent af hovedstadens areal således var bebygget, udgjorde rekreative områder her ikke mindre end 28 procent. Tilvejebragt for godt og vel halvdelen af henholdsvis by- og folkeparker i hovedstadens mere centrale dele og rekreative naturområder i de ydre dele ved mose- og søområder.

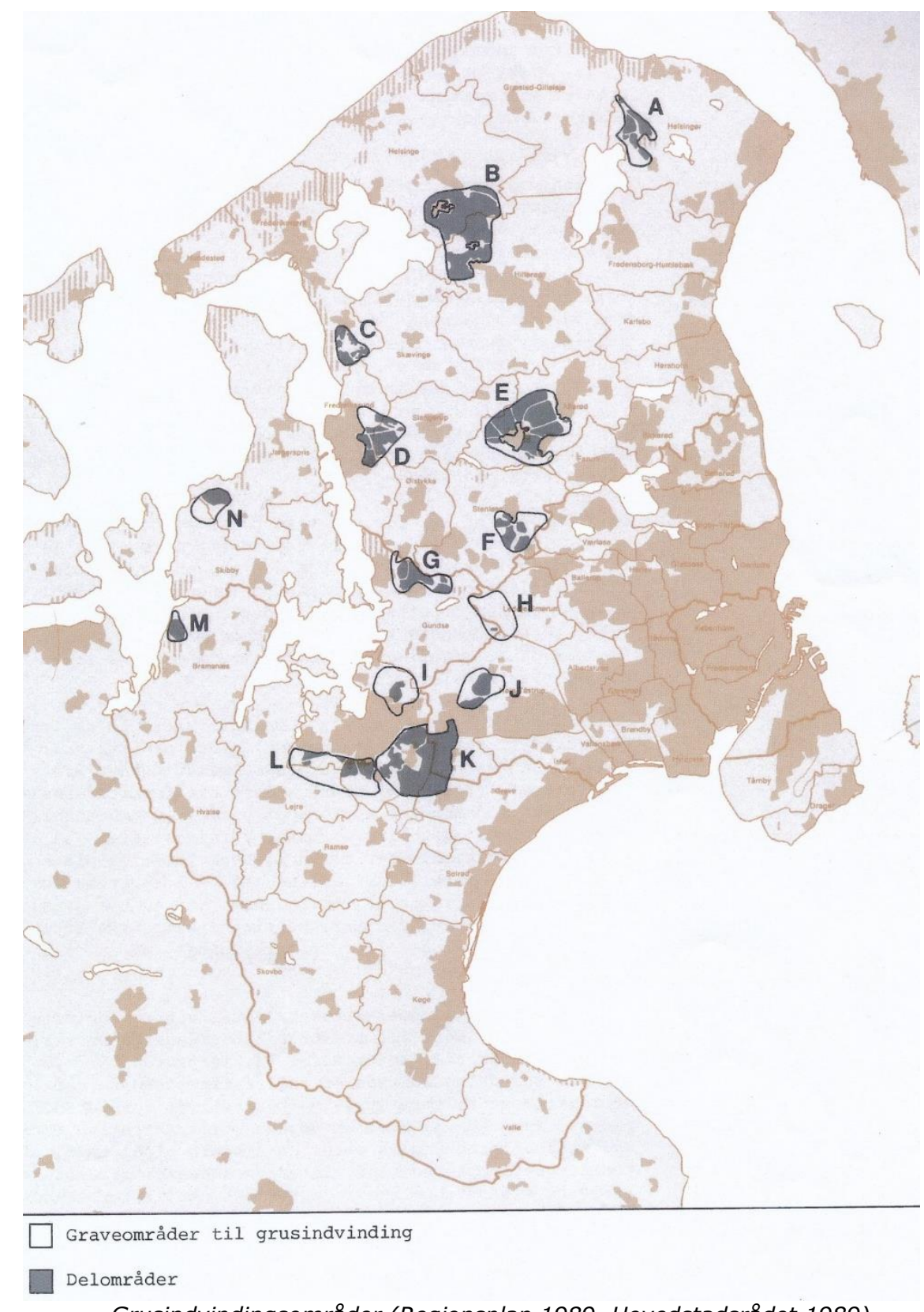

Grusindvindingsområder (Regionsplan 1989, Hovedstadsrådet 1989)

Alternative fritidsbosætningsformer

Ud over sikring af højklassede landskabs- og kystområder og almenhedens adgang til meget omfattende og samtidig differentierede rekreative områder tilvejebragte Hovedstadsrådet samtidig rammebetingelser for alternative fritidsbosætnings- og friluftslivsformer. For at inddæmme behovet for udlæg af nye sommerhusbyer og som en del af de regionale rekreative arealdispositioner opstillede regionsplantillægget fra 1985 og Regionsplan 1989, ud fra de anbefalinger Egnsplanrådet i sin tid var kommet med forud for Regionsplan 1973, muligheder for andre fritidsbosætningsformer. 


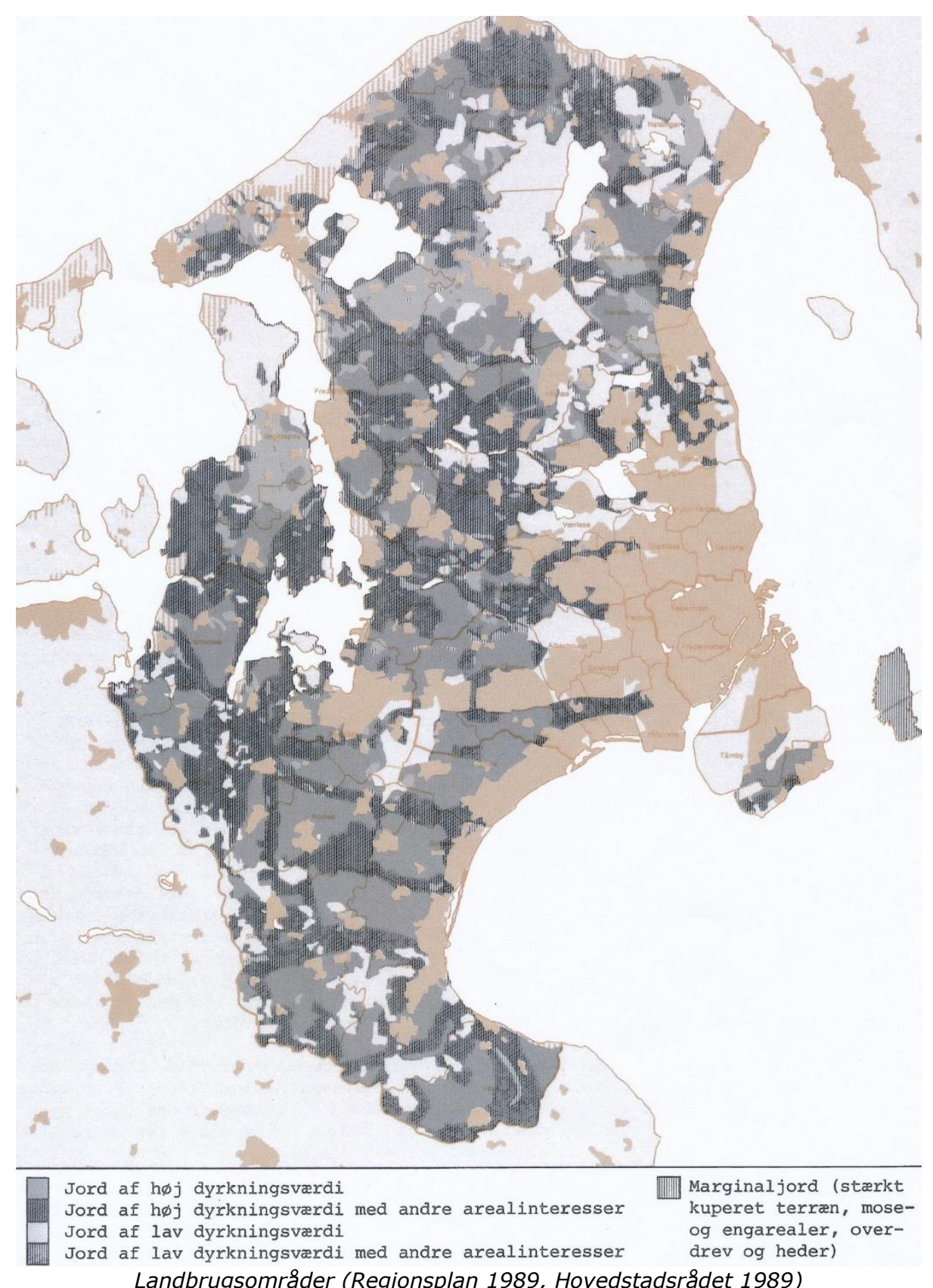

Heri indgik bl.a. en række retningslinjer for lokalisering af kolonihaveområder. Det understregedes i den forbindelse, at eksisterende kolonihaveområder burde bevares, og at der i tilfælde af nedlæggelse skulle tilvejebringes erstatningsarealer. Herudover anvistes tre typer af kolonihaveformer, som kommunerne i den stedlige kommune- og lokalplanlægning skulle ligge til grund ved nye udlæg af kolonihaveområder i form af:

Dels beboerhaver direkte integreret i de enkelte kvarterer med etagebyggeri. Dels daghaver i direkte tilknytning til boligområderne overalt i hovedstadsmetropolens område. Dels såkaldte regionale overnatningshaveområder, der placeredes så tæt på brugernes boligområder og kollektive trafikforbindelser som muligt, og som Hovedstadsrådet udpegede seks lokaliseringssteder for i Solrød, Greve, Ishøj, Høje Tåstrup og Ledøje-Smørum kommuner samt på Vestamager. Samlet forskellige former for kolonihaveområder i den indre del af hovedstadsmetropolen, hvor koncentrationen af etagebyggeri var stor, og hvor der af 
velfærdspolitiske hensyn var størst behov for at give den stedlige befolkning adgang til den friluftoplevelse, som en kolonihave indebar.

For samme befolkningssegment, der af økonomiske grunde ikke havde adgang til have i eget hus eller sommerhus, var der allerede i den første efterkrigstid i forlængelse af fredninger udlagt et betydeligt antal campingpladser i hovedstadsmetropolens åbne land og med Hovedstadsrådets 1985-regionsplantillæg og i Regionsplan 1989 anvistes yderligere 13 områder det dette formål, hvoraf knapt halvdelen i tilknytning til metropolens sommerhusbyer. For så vidt lystbådehavne, fastlagde såvel regionsplantillægget fra 85 som regionsplanen fra 89 , at der ikke måtte udlægges nye havneanlæg til dette formål i velhaverbælterne langs Øresund og Kattegat. Da jollesejllads og mere ydmyge lystbåde kunne være en til sommerhuset alternativ friluftslivsform, blev der til gengæld lagt op til udvidelser af eksisterende og etablering af nye havneanlæg i kystområder i de tæet bebyggede indre dele af hovedstadsmetropolen, langs Køge Bugt og ved Roskilde Fjord og Isefjorden. ${ }^{43}$

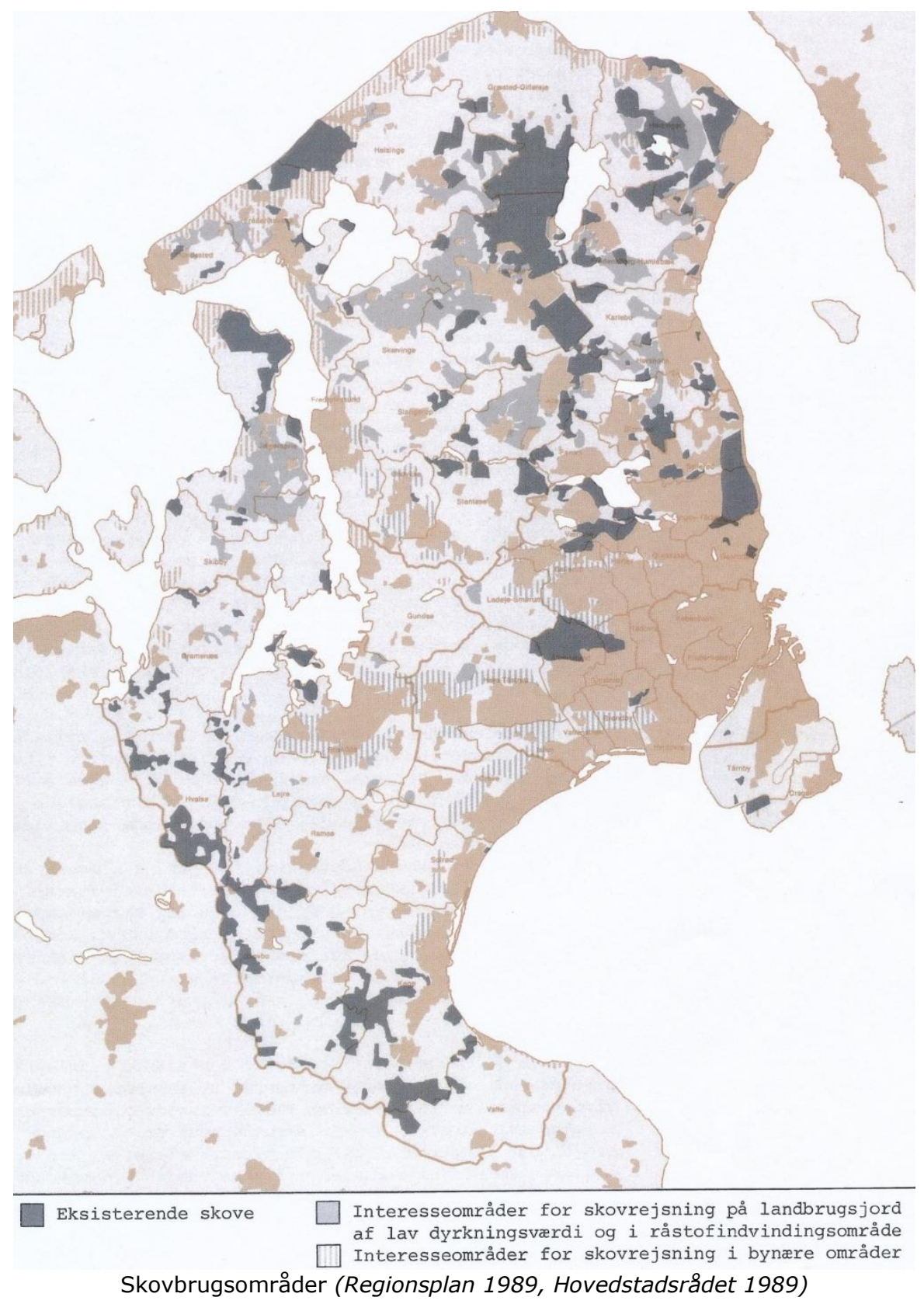


Råstofindvinding og land- og skovbrug

Med velfærdsstatens regulering af de sideeffekter, der fulgte af efterkrigstidens mere intensive landog skovbrug og råstofindvinding, kom Hovedstadsrådets, og i det øvrige lands amtskommunernes, regionale sektorplanlægning af det åbne land i den sidste efterkrigstid også til at omfatte disse problemstillinger. Styrede blev ikke blot en inddæmning af de skader, den erhvervsmæssige udnyttelse af landskabet kunne påføre dets naturværdier og almenhedens adgang hertil, men også at dirigere den i en retning så den kunne understøtte disse naturbeskyttede og rekreative interesser.

Hovedstadsrådet gennemførte således i løbet af 80 'erne en for kommunerne bindende råstofindvindingsplanlægning, der tillige blev indskrevet i årtiets regionsplantillæg og regionsplan, og som udpegede 14 grusgravningsområder i hele hovedstadsmetropolens område, hvoraf syv havde regional betydning og de øvrige syv lokal. Områderne blev reserveret til grusgravning på lang sigt, og måtte ikke beslaglægges til andre formål, som kunne vanskeliggøre yderlige grusudvinding. Uden for de udstukne områder måtte, der af rekreative og naturbeskyttende hensyn ikke finde yderligere grusgravning sted, ligesom Hovedstadsrådets grusgravsplanlægning af samme hensyn udpegede grusgravsområder, bl.a. ved Hvalsø og Køge ås, hvor aktiviteterne skulle afvikles, og områderne skulle tilbageføres til deres oprindelige naturlige tilstand. Hovedstadsrådet udarbejdede tilsvarende planer for lergravning, og i 1985 samledes alle retningslinjerne for udnyttelse af forekomster af sand, grus, sten, ler, kalk og tørv i en særlig råstofindvindingsplan. Herudover kom rådsforvaltningen til at behandle og træffe afgørelse i sager om ansøgninger om råstofindvinding og udvidet indvinding, og skulle føre tilsyn med råstofindvindingen og i den forbindelse påbyde genopretningsforanstaltninger

På grundlag af Landbrugsministeriets klassificering af landbrugsjorden udarbejdede Hovedstadsrådet desuden i $80^{\prime}$ erne sektorplaner for særligt værdifulde landbrugsområder, der senere indarbejdes i regionsplantillæggene og Regionsplan 1989. Den særlige sektorplan på området udpegede beliggenheden, størrelsen og dyrkningsværdien af arealer i hovedstadsmetropolens åbne land, der skulle forbeholdes landbrug. Målet var at fastholde områderne som dels produktionsgrundlag for aktivt landbrug, dels beboede og åbne arealer med bevarelse af de landskabelige og kulturhistoriske værdier, der netop knyttede sig til landbrugsområderne, og dermed forhold, der indgik i Hovedstadsrådets samtidige udpegning af fredningsinteresseområder.

Bymæssige eller andre tekniske anlæg end dem, der var nødvendige for beboerne og landbruget, skulle undgås i de til landbrug udlagte områder, dog således at der i kilerne mellem forstadsbåndene og de tværgående grønne bælter i hovedstadsmetropolens indre dele kunne gennemføres skovplantning. Et element, der indgik i Hovedstadsrådets tilsvarende udpegning af og retningslinjer for dels eksisterende skove, dels meget betydelige skovrejsninger af almene rekreative hensyn i både bynære områder eller i landbrugsområder med jord af lav dyrkningsværdi. Også på dette sektorplanområde fik rådsforvaltningen en række administrative og tilsynsmæssige opgaver. Bl.a. behandling af ansøgninger om opgivelse af landbrugspligten i det åbne land, som forvaltningen ofte modsætte sig af hensyn til bevaring af det åbne lands landskabsmæssige og kulturhistoriske karakter af værdi for almenhedens friluftsliv. ${ }^{44}$

\section{Den regionale sommerhusbyplanlægning}

Et centralt omdrejningspunkt i Hovedstadsrådets altomfattende regionale sektorplanlægning af anvendelsen af hovedstadsmetropolens åbne land i den sidste efterkrigstid, blev den hidtidige og forventede sommerhusbysspredning. En problemstilling, der ikke blot kendetegnede metropolens åbne land og kystområder, men tillige andre dele af landet, hvor sommerhusbysspredningen lagde afgørende barrierer for de helt overvejende socialdemokratiske regeringers aktive rekreative polititik tilsigtende: Størst og flest mulige rekreative områder for befolkningen som helhed og tilvejebringelse af alternative fritidsbosætnings- og friluftslivsformer. I en sådan grad, at sommerhusbyplanlægningen i både Hovedstadsrådets og landets øvrige amtskommuners sektorplanlægning af det åbne lands anvendelse i den sidste efterkrigstid blev stærkt styret af en række centralstatslige sigtelinjer. 


\section{Centralstatslige sigtelinjer}

Allerede i forbindelse med førnævnte lancering af den socialdemokratiske regerings aktive rekreative politik i 1972 kunne det således herfra konstateres, at der var opført 150.000 sommerhus, og at der på den baggrund "forlods gennemføres forskellige lovændringer til styrkelse af samfundets indseende med arealanvendelsen i det åbne land og i områder af betydning for befolkningens rekreative interesser". ${ }^{45}$ Grundlaget for samme års, ligeledes førnævnte, lovgivning om sommerhuse og erhvervelse af fast ejendom til fritidsformål tilsigtende en inddæmning af sommerhusbysspredningen og tilvejebringelse af almennyttige til sommerhuset alternative fritidsbosætningsformer.

Samtidig med den lovgivning fra 1959, der forhindrede udenlandske erhvervelse af jord, som ikke tjente erhvervsmæssig virksomhed, opretholdtes, fik sommerhusloven til formål at regulere omfanget af erhvervsmæssig udlejning af uden- eller indenlandsk ejede nyetablerede sommerhuskolonier eller opkøbte sommerhuse i eksisterende sommerhusbyer. En erhvervsmæssig virksomhed, der med landets snarlige indtræden i EF ureguleret ville lægge beslag på større dele af sommerhusbyerne, og dermed med tidens stadig store efterspørgsel på sommerhusgrunde og- huse ville forstærke den sommerhusbysspredning, som ville komme i konflikt med regeringens aktive rekreative politik i henseende til tilvejebringelse af yderligere rekreative områder og alternative fritidsbosætningsformer.

I samme øjemed fik Boligministeriet beføjelse til, efter indstilling fra primær- eller amtskommuner, at påbyde, at alene ledige sommerhusgrunde i eksisterende sommerhusbyer blev bebygget med sommerhuse og maksimale grundstørrelser og mindst husstørrelser i sommerhusbyer. Målet var at udnytte den fulde sommerhuskapacitet i disse sommerhusbyer for dermed også ad den vej at begrænse behovet for udlæg af yderlige nye. Af hensyn til det offentliges og almennyttige organisationer erhvervelse af rekreative arealer og disses anvendelse til almene alternative fritidsbosætningsformer, udrustedes Boligministeriet desuden med beføjelser til, på indstilling af primær- og amtskommune, at regulere private selskabers, andre foreningers og private institutioners, stiftelsers og legaters opk $ø \mathrm{~b}$ af sådanne arealer. ${ }^{46}$

Selv om der med sommerhusloven i 1972 således blev givet centralstatslige beføjelser, der skulle kunne bidrage til en inddæmning sommerhusbysspredningen, var sommerhusbyggeriet fortsat i de følgende år af 70 'erne, hvor Hovedstadsrådets og amtskommunernes videre regions- og sektorplanarbejde alene var nået til den indledende fase, og derfor endnu ikke var kommet til at omfatte det åbne land og dermed kystområderne og disses baglande, hvor sommerhusbyer i overvejende grad var lokaliseret til. I det lys kom sommerhusbysspredningen til at stå centralt i den første statslige landsplanredegørelse fra 1975.

På grundlag af detaljerede undersøgelser gennemført tilbage i 1970 konstaterede redegørelsen, at der $\mathrm{i}$ de ubebyggede områder $\mathrm{i}$ allerede udlagte sommerhusbyer var arealer til yderligere 80.000 sommerhuse, men at disse med et estimeret årligt byggeri af 8.000 sommerhus ville være opbrugt ved indgangen til det nye årti. Med denne udbygning af eksisterede sommerhusbyer forudså landsplanredegørelsen en kommende sommerhusbysspredning som en alvorlig trussel mod kystlandskabets værdi og rekreative anvendelse. Helt som det var tilfældet ved Kattegatkysten og ned langs Roskilde Fjords nordlige østside, forudså redegørelsen lange sammenhængende sommerhusbyer langs landets kyststrækninger og disses baglande, der hermed ville blive afspærret for andre former for friluftsliv og frataget deres betydelige naturværdi.

I forbindelse med landsplanredegørelsen blev det fra den siddende socialdemokratiske regerings side udtrykt et klar ønske om, at der blev truffet foranstaltninger mod spredning af sommerhusbyer til kystnære områder, som det udtryktes, "så den øvrige befolkning făr adgang", og for "at også mennesker, der ikke har råd til hotelophold eller sommerhus, kan komme der". ${ }^{47}$ Modsætningsforholdet mellem den individuelle friluftsbosætningsform, som sommerhusbyerne var udtryk for, og velfærdsstatens hensyn til brede samfundslags mulighed 
for at udleve et rekreativt friluftsliv og eventuelt at fritidsbosætte sig i samme områder var på ny sat i spil.

Ud fra velfærdssystemets kultur- og fritidssøjle valgte velfærdsstaten i dette spændingsfelt igen og nu med mere effektfulde virkemidler at prioritere de almene friluftshensyn højere end de individuelle i et cirkulære om planlægning af sommerhusområder fra 1978 . Heri lagdes for første gang rammerne for den sommerhusplanlægning, der skulle indgå i Hovedstadsrådets og det øvrige lands amtskommuners planlægning af det ăbne lands anvendelse. Inden denne sommerhusbyplanlægning var afsluttet og indarbejdet i af Miljøministeriet godkendte regionsplaner eller et tillæg hertil, måtte der i hele landet foreløbig ikke udlægges nye sommerhusbyer.

Ved sommerhusbyplanlægning skulle Hovedstadsrådet og de øvrige amtskommuner efter cirkulæret tage udgangspunkt i dels samlede regionale overvejelser om den rekreative udvikling i hovedstadsmetropolen og i de enkelte af landets øvrige amtskommuner, dels at kystnære områder, i cirkulæret udpeget til områder med en udstrækning fra kystlinjen på 1-3 $\mathrm{km}$ ind i baglandet, skulle friholdes for udlæg af nye sommerhusbyer og udvidelse af eksisterende. Sådanne udlæg og udvidelser skulle desuden forhindres i områder op til grænserne for de kystnærer områder for dermed at hindre, at der her opstod nye kæder af sommerhusbyer. Nye sommerhusbyer skulle således som afgrænsede enklaver alene henvises til områder længere inde i kystbaglandet, hvor der samtidig kunne opnås tilslutning til mindre bysamfund og disses eksisterende servicefunktioner og tekniske anlæg.

Endelig skulle Hovedstadsrådet og landets øvrige amtskommuner efter cirkulæret overveje, om og hvordan allerede udlagte, men ikke bebyggede dele af eksisterende sommerhusbyer kunne anvendes til andre mindre arealkrævende fritidsbosætningsformål så som campingpladser, feriebyer, feriecentre m.m. Fritidsbosætningsformer, der særlig kunne stilles til rådighed for de samfundslag, der økonomisk ikke magtede erhvervelse og besiddelse af et sommerhus.

For netop at lede den regionale sommerhusbyplanlægning og hele sektorplanlægningen af arealanvendelsen af det åbne land i den retning, afsattes i 1978 ved et landspolitisk forlig yderlige statsmidler til etablering af feriebyer, hvilket bl.a. førte til, at Danske Folkeferie etablerede feriecentre ved Karrebæksminde, Karlslunde Strand og Sandvig og totalrenoverede ældre ved Sæby og Middelfart. I hovedstademetropolens åbne land gav statsmidlerne mulighed, for at Dansk Folkeferie i 1979 og 1983 kunne erstatte den ældre koloni af feriehytter i Gilbjerg Huse med et nyt og langt større feriecenter med 87 nye huse med stue, to værelser, køkken og bad og et stort centralanlæg med ferielejligheder, restauranet, individuelle swimmingpool, forskellige aktivitetsfaciliteter og kursuslokaler. ${ }^{48}$

\section{Sommerhusplanlægningen i hovedstadsmetropolen}

Selv om Egnsplanrådet i forarbejderne op til Regionsplan 1973, som anført ovenfor, havde skudt en regional planlægning af sommerhusbysspredningen til hjørne, idet dette på området lagde op til en interregional planlægning sammen med amtskommunerne på den øvrige sjællandske øgruppe og kommunerne i en del af Skåne, kom et forbud mod udvidelse af eksisterende og udlæg af nye sommerhusbyer $\mathrm{i}$ hele hovedstadsmetropolen til at indgå i regionsplanen ved dennes godkendelse af Hovedstadsrådet i 1974 og siden af Miljøministeriet i 76.

Et meget radikalt planindgreb over for den hidtidige meget beskedent regulerede og planlagte sommerhusbydannelse, der udsprang af dennes kritiske udbredelse i hovedstadsmetropolens begrænsede kyststrækninger, landskaber og alment rekreative områder, og foranledigede Hovedstadsrådet til at oprette bestemmelsen både i Første Etapeplanen fra 1978, over 80 'ernes regionsplantillæg og helt frem til og med Regionsplan 1989.49 En disposition, som dog ikke fritog Hovedstadsrådet for at udarbejde en sommerhusbyplanlægning og indpasse den i sektor- og regionsplanlægningen for arealanvendelse af hovedstadsmetropolens åbne 
land efter 1978-cikulæret og dettes revision ved det nye cirkulære fra 1981 om af ferie- og fritidsbebyggelse, der tillige omfattede feriehoteller -, byer - og centre og campingpladser. ${ }^{50}$

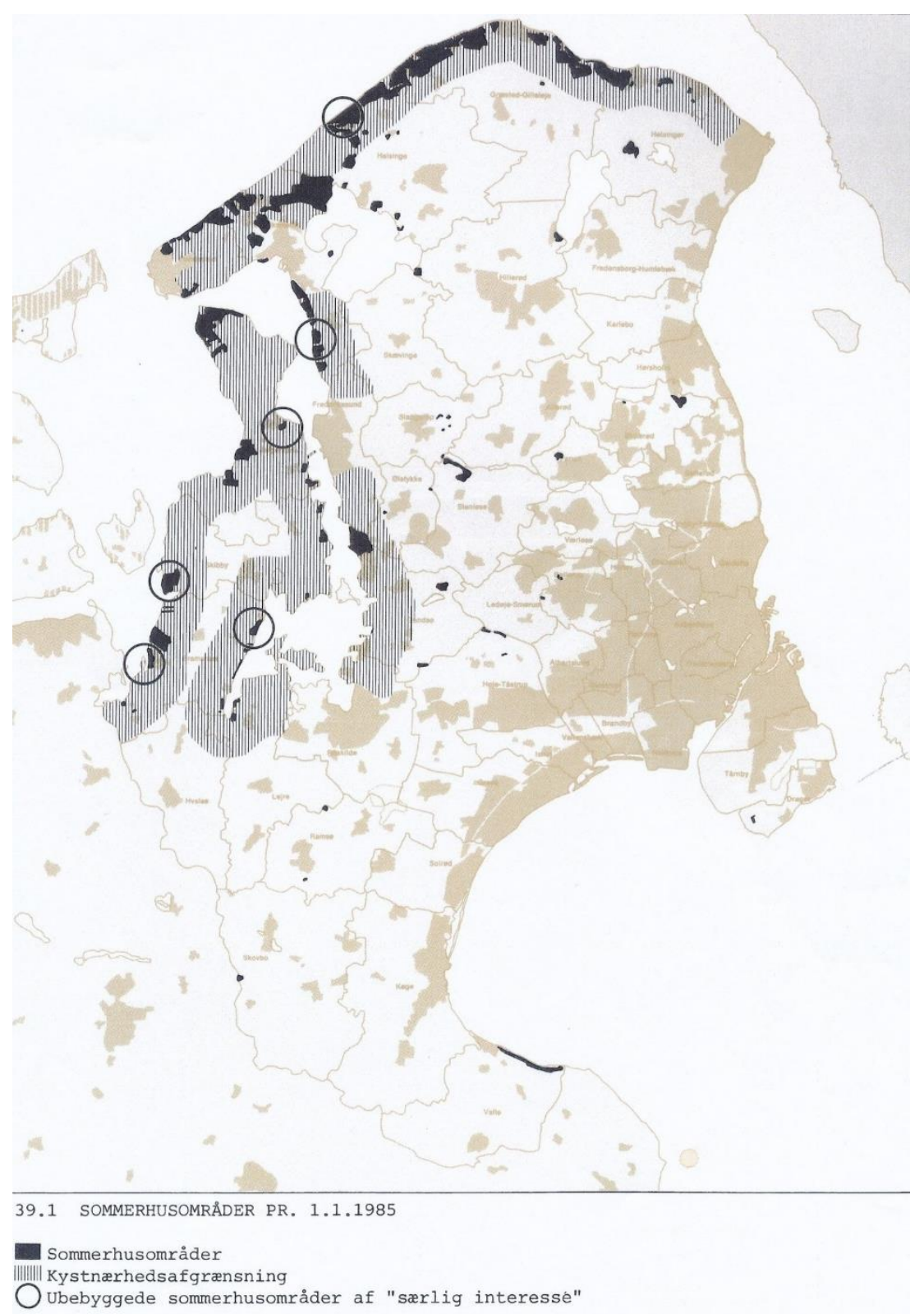

Fritidsbosætningsplanlægningen efter 80 'ernes regionsplantillæg (Regionsplantillæg, Hovedstadsrådet 1983)

På dette grundlag udarbejde Hovedstadsrådet i slutningen af 70 'erne en sommerhusbyplanlægning eller rettere en fritidsbosætningsplanlægning, der i første omgang afspejledes i Første Etapeplanen fra 1978 og senere indarbejdes i 80' ernes regionsplantillæg og Regionsplan 1989.51 Udover gentagne gange at foreslă, at der i hovedstadsmetropolen ikke måtte udlægges nye sommerhusbyer eller gennemføres udvidelse af eksisterede, bestemte Hovedstadsrådets fritidsbosætningsplanlægning for sidstnævnte sommerhusbyer, at disse skulle fastholdes til sommerhusanvendelse, ikke måtte overgå til helårsboligområder, og at deres rekreative værdi skulle sikres gennem primærkommunernes kommune- og lokalplaner.

Undtagelsen herfor var dog enkelt sommerhuse i landsbyer og eller samlede bebyggelser med helårshuse, fortrinsvis pendlersatellitbyer, hvor sommerhuses overgang til helårsbeboelse kunne ske gennem tilladelse efter by- og landzonelovgivningen eller en lokalplan. Herudover 
kunne i enkelte tilfælde eksisterende sommerhusbyer eller dele heraf overføres til byzone, under forudsætning af sommerhusbyen grænsede direkte op til en eksisterende byzone, og at sommerhusene blev helårsbeboet og opfyldte de størrelsesmæssige og kvalitative krav til helårsboliger. Endelig forudsattes det, at det samlede udbud af sommerhuse ikke blev beskåret væsentligt, og at det forøgede byzoneområde og den reducerede sommerhusby fik en rimelig og naturlig størrelse og afgrænsning.

Efter 1978-cirkulæret udlagde Hovedstadsrådets fritidsbosætningsplanlægning desuden en tre $\mathrm{km}$. bred kystnærhedszone langs Kattegatkysten, Roskilde Fjord og Isefjordens østkyst inden for hvilken, der nedlagdes forbud mod etablering af nye anlæg, opførelse af nye bebyggelse og udvidelse af eksisterende anlæg og bebyggelse til ferie- og fritidsformål. Undtaget var dog, i fald at offentlighedens kystadgang ikke forringedes, sommerhuse i eksisterende sommerhusbyer og af hensyn til fremme af til sommerhus alternative fritidsbosæetningsformer: Etablering af mindre feriecentre og mindre udvidelser af eksisterende sådanne samt campingpladser. For netop her at sikre beboerne i feriecentre og på campingpladser og almenheden i øvrigt adgang til kystlinjen, opkøbte kommunerne ved Kattegatkysten og Vallø Kommune ved Strøby Strand med støtte fra den Hovedstadsfond, som Hovedstadsrådet administrerede, samtidig ganske betydelige områder. ${ }^{52}$

Til dette formål lagde Hovedstadsrådets fritidsbosætningsplanlægning endelig op til, at ubebyggede dele af eksisterende sommerhusbyer ikke udstykkedes eller bebyggedes med sommerhuse, men at disse kunne overgå til mindre arealekstensiv fritidsbosættelse så som campingpladser, feriebyer, vandrehjem, hytteudledning m.m. Et plangreb, som allerede i starten af 70 ' erne indgik i de statslige første pejlemærker for sommerhusplanlægningen, og visionært var blevet omsat til konkrete forslag i forarbejderne op til Regionsplan 1973. Med dette formål udpegede Hovedstadsrådets regionsplanstillæg ni områder af særlig interesse for en sådan anvendelse. To på Hornsherreds Isefjords kyst, tre på halvøen del ved Roskilde Fjord, et ud til samme fjord mellem Frederikssund og Frederiksværk og tre i henholdsvis Liseleje, Asserbo og Tisvildeleje. ${ }^{53}$

Selv om deres antal i midten af 80 'erne måtte reduceres til seks, lykkedes det i fire tilfælde for Hovedstadsrådet ved forhandlinger med kommunerne, staten og de stedlige grundejere i slutningen af 80 'erne at komme igennem med sine målsætninger for de særlige interesseområder. De endnu ikke bebyggede dele af Vieholmgårds jorde ved Sankt Helene Kilde i Tisvildeleje opkøbtes således med støtte fra Hovedstadsrådet af staten og Helsinge Kommune, og udlagdes af de tre offentlige aktører til et stort for offentligheden tilgængeligt område, hvori placeredes en naturskole, og et vandrehjem, som senere som en del Herbergsringens nye virksomhed Danhostel kom til at indgå i samme områdes Sankt Helenes Ferie- og Kursuscenter, der tilbød udlejning af ferielejligheder, familieværelser og hytter $i$ et større fritidsressort med forskellige former for aktiviteter.

I sommerhusbyen ved Gershøj i Hornsherred ved Roskilde Fjord opkøbte staten med Hovedstadsrådet medvirken et område, der åbnedes for offentligheden, og hvorpå en mindre teltplads og en anløbsplads ved fjorden udlagdes. På halvøens Isefjordskyst opkøbtes på tilsvarende måde af staten områder i sommerhusbyen ved Ejby og Hammeren i Vellerup Sommerby. I Ejby udlagdes i området teltplads, mens der i Vellerup blev lagt planer for en naturskole og mulighed for hytteudlejning. I den lille sommerhusby Færgelunden på Hornsherred lige over for Frederikssund og ved det nordlige kystbælte på Roskilde Fjords østside forblev de ubebyggede områder som så i privat eje, uden at Hovedstadsrådet eller andre offentlige aktører fik mulighed for nærmere at disponere over disse. ${ }^{54}$

\section{Sommerhuslovens skærpelse}

Selv om Hovedstadsrådets fritidsbosætningsplanlægning fik bremset sommerhusbysspredningen i hovedstadsmetropolen og indpasset de eksisterede sommerhusbyer i den samlede sektorplanlægning af dens åbne lands anvendelse, og der i et vist omfang blev opnået tilsvarende resultater $\mathrm{i}$ amtskommunerne uden for 
hovedstadsmetropolen, var den tiltagende helårsbosættelse i sommerhusbyer sideløbende med denne planlægningsproces begyndt at undergrave forudsætningerne for denne. På den baggrund nedsatte den socialdemokratiske regering i 1980 et udvalg, der skulle stille forslag til, hvorledes denne utilsigtede anvendelse af sommerhusbyerne kunne imødegås. Udvalget afgav året efter en betænkning, men da dens lovforslag først blev fremlagt umiddelbart efter den konservativt ledede centrum-højre regeringen havde taget over, blev dets rækkevidde, som følge af den vanlige borgerlige højere grad af hensyntagen til individuelle interesser end de samfundsmæssige, beskåret.

Den ændrede sommerhuslov, der trådte i kraft i 83 fastslog ganske vist, at sommerhuse ikke måtte anvendes til overnatning i perioden 1.10 til 31.1 på nær kortvarige ferieophold, og forudsatte, at ejeren havde en folkeregisterregisteret bopæl andet steds. Men i rummede i forhold til udvalgsbetænkningens lovforslag betydelige lempelser, der indebar, at enkeltpersoner under bestemte vilkår kunne opnå en personlig kommunal dispensation for forbuddet mod helårsbeboelse af sommerhus, ligesom den toårige afviklingsperiode af den aktuelle ulovlige helårsbeboelse i udvalgsbetænkningens lovforslag udvandedes betydeligt i den gennemførte sommerhuslov. Alle, der inden en bestemt dato inden lovændringens ikrafttrædelse ulovligt helårsbeboede et sommerhus, kunne således opnå personlig kommunal tilladelse til at forsætte denne beboelse så længe, den pågældende var i besiddelse af vedkommende sommerhus. Enhver helårsbeboelse af sommerhuse, der ikke havde opnået de kommunale personlige dispensationer til at fortsætte den hidtil aktuelt ulovlige helårsbeboelse af samme, ville derimod bliver indbragt for domstolene med henblik på efterfølgende bødeforlæg og i værste fald fogedudsættelse. ${ }^{55}$

\section{Regionale rammebetingelser}

Med Hovedstadsrådets virksomhed op gennem den sidste efterkrigstid tilvejebragtes ud over regionsplanlægningen og sektorplanlægningen for anvendelsen af det åbne land en lang række andre regionale rammebetingelser for hovedstadsmetropolens videre udvikling som en funktionel byregion. Selv om 60' ernes vidtrækkende motorvejsplaner, som følge af periodens kriser og landspolitisk opprioritering af den kollektive trafik, under Hovedstadsrådets regionale trafikplanlægning alene fuldførtes i de indre dele af hovedstadsmetropolen, hvor trafikpresset var mest voldsomt, omfattede denne sektorplanlægning tillige den kollektive trafik.

På dette område opnåede Hovedstadsrådet sine største resultater, idet alle sider af den kollektive trafiks drift blev underlagt rådets Hovedstadsområdet Trafikselskab (HT), der etablerede et samlet og sammenhængende enhedssystem med samme køreplans- og takstordning for både S- og regionalbaner og alle former for busdrift. I dette system varetog $\mathrm{HT}$ selv en betydelig del af busdriften, mens den øvrige del af denne på entreprenørkontrakt udførtes af private aktører. Helt tilsvarende S- og regionalbanedriften, hvor DSB var udførende entreprenør for HT. Samlet skabte Hovedstadsrådet trafikplanlægning og HTs meget betydelige forbedring af den kollektive trafik stærkt forberede rammebetingelser for varers, tjenesters og arbejdskrafts bevægelighed mellem hovedstadsmetropolens funktionelt forskelligartede byenheder.

For arbejdskraftens produktionsevne og realkapitalens funktionalitet ydedes tillige et afgørende bidrag gennem Hovedstadsrådets sektorplanlægning og konkrete tilsynsmæssige og administrative virksomhed $i$ henseende til regional vand- og energiforsyning af og spildevandslednings- og affaldshåndtering fra boligområder og produktionsanlæg - og områder. For arbejdskraftens produktionsevne medvirkede Hovedstadsrådets sygehusplanlægning til, at sygehustilbuddet i hele hovedstadsmetropolen ikke blot højnedes, men tillige blev regionalt mere ensartet.

Selv om Hovedstadsrådets betydelige regionale dispositioner skabte afgørende forbedrede rammebetingelser for interaktionen mellem hovedstadsmetropolens funktionelt forskellige byenheder overvejende i metropolens centrale del, kom de også til at få indflydelse på de 
ørige regionsudfordringer, der udsprang af efterkrigstidens sommerhusbydannelse, og de mere delregionale rammebetingelser, som var afgørende for disses samspil med metropolens $\varnothing v$ rige byenheder og dermed for hele hovedstadsmetropolens funktionalitet som en byregion. ${ }^{56}$

\section{Det regionale vejnet}

Selv om Holbæk- og Helsingørmotorvejene tidligt i den sidste efterkrigstidsperiode færdiggjordes i fuld udstrækning, og dermed sikrede en højklasset forbindelse til sommerhusbyerne i den sydlige del af Hornsherred og den østlige del af sommehusbybæltet ved Kattegat, skabte periodens beskæringer af 60 'erne store motorvejsplaner betydelige vejtrafikale udfordringer i forstadsbåndet langs den ydre del af Frederikssundsbanen og i det nordligste Nordsjælland. Netop, der hvor den sidste efterkrigstids by- og befolkningstilvækst i hovedstadsmetropolen navnlig fandt sted og samtidig der, hvor trafikpresset forstærkedes i ferieperioderne og weekends som følge af de store sommerhusbyer i den nordlige del af Hornsherred, ved Roskilde Fjords østkyst og Kattegatkysten.

Udfordringer, som hovedstadsmetropolens ydre amtskommuner og staten i den sidste efterkrigstid forsøgte at inddæmme ud fra Hovedstadsrådets Trafikplan 1980. I stedet for helt af opgive Hillerødmotorvejens videre nordlige forløb, blev den i stedet udlagt som trafikmotorvej fra Allerød til lige syd for Helsinge og Græsted, hvorved der skabtes forbedrede vejforbindelser til de fleste satellitbyer i det nordligste Nordsjælland og hovedparten af den $\varnothing$ vrige del af sommerhusbybæltet ved Kattegatkysten. Af betydning for vejtrafikken hertil og satellitbyer og sommerhusbyer i den øvrige del af hovedstadsmetropolens åbne opland blev tillige amtskommunernes udvidelse af både radiale og tværgående landeveje.

Således blev Isterødvejen, Frederikssundsvejen og landevejsstrækningen fra Frederikssund over Slangerup til Hillerødmotorvejen ved Farum udvidet til enten firesporede eller brede tosporede landeveje, der alle forlagdes til ringsvejsforløb uden om større bysamfund. Samtidig hermed udlagdes betydelige omfartsveje uden om Hillerød og gennemførtes tilsvarende udvidelser af gennemgående tværlandeveje, f.eks. af strækningen Helsingør-Frederiksværk, dele af strækningerne Frederiksværk- Ølstykke, Helsingør-Hillerød-Roskilde, FrederikssundRoskilde i Hornsherred og af landeveje syd og vest for Køge.

Landevejsudvidelserne fik betydning for lokaltrafikken i disse områderne og opsugede tillige i et vist omfang de stigende trafikmængder i hovedstadsmetropolens ydre dele, men blev ikke tilstrækkelige i forhold til hovedstrømmen af bilpendling mellem hovedstadsmetropolens sommerhusbyer, satellitbyer, forstadsbånd og selve hovedstaden og slet ikke i forhold til den meget betydelige tværgående biltrafik, der forsat i vid udstrækning måtte ledes af de to ringmotorveje i den indre del af metropolen. En problematik, som førte til, at Regionsplan 1989 lagde op til en genoplivning af Motorring 5, der oprindelig indgik som motorvej i Regionsplan 1973s transportkorridor, i form af en ringmotortrafikvej fra Høje Tåstrup til Allerød og en forlængelse af Frederiksundsmotorvejen fra Motorring 4 til den nye ringvej. Igen af disse anlæg blev dog foreløbig gennemført. ${ }^{57}$

\section{Den kollektive trafik}

Ude i hovedstadsmetropolen ydre opland, hvor dens sommerhusbyer var lokaliseret, søgte HT også at udvide både sidebane- og busdriften og at opnå en fuld integration af samtlige buslinjer, disses forbindelse med hinanden og med S-, regional- og sidebanerne, således at hele metropolen opnåede en samlet langt større kollektivtrafikal sammenhængskraft. I driftsårene i 70 'erne nyudlagdes således mellem nogle af købstadsringens købstæder og de mere centrale dele af hovedstadsmetropolens indre flere lange radiallinjer. Bl.a. ruterne Helsingør-Hørsholm-Lyngby, de gamle linjer Køge-Valby Station og Roskilde-Valby Langgade Station samt Standvejslinjen Klampenborg-Helsingør. Fra de ydre S-banestationer og fra købstadsstationerne, hvorfra der var hurtig S- eller regiontogsforbindelse til hovedstadsmetropolens indre dele og selve hovedstaden, udlagde HT desuden et større net af buslinjer til de mere rurale oplande, der sammen med opgraderingen af driften af sidebanerne 
i samme oplande, skabte en stærkt forbedret kollektiv trafik i disse dele af metropolen med hurtigere og hyppigere forbindelser herfra til dens mere centrale dele. Herudover udlagdes dels en række radiale buslinjer, der rakte langt ind i de tilstødende amtskommuner, dels linjeføringer, som skabte lange tværgående forbindelser mellem ydre destinationer $i$ hovedstadsmetropolen og udenfor: F.eks. så såkaldte landevejsruter mellem Roskilde-Køge Bugt og på strækningerne Køge-Ringsted, Roskilde-Hillerød, Hillerød-Farum, FarumFrederikssund, Frederikssund-Hillerød , Frederikssund-Kulhuse, Frederikssund-Frederiksværk, Frederiksværk-Hillerød, Frederiksværk-Helsinge-Helsingør, Gilleleje-Rågeleje, StenløseFrederikssund, Frederikssund-Skibby-Hvalsø, Roskilde-Skibby og Hvalsø-Solrød Strand. ${ }^{58}$

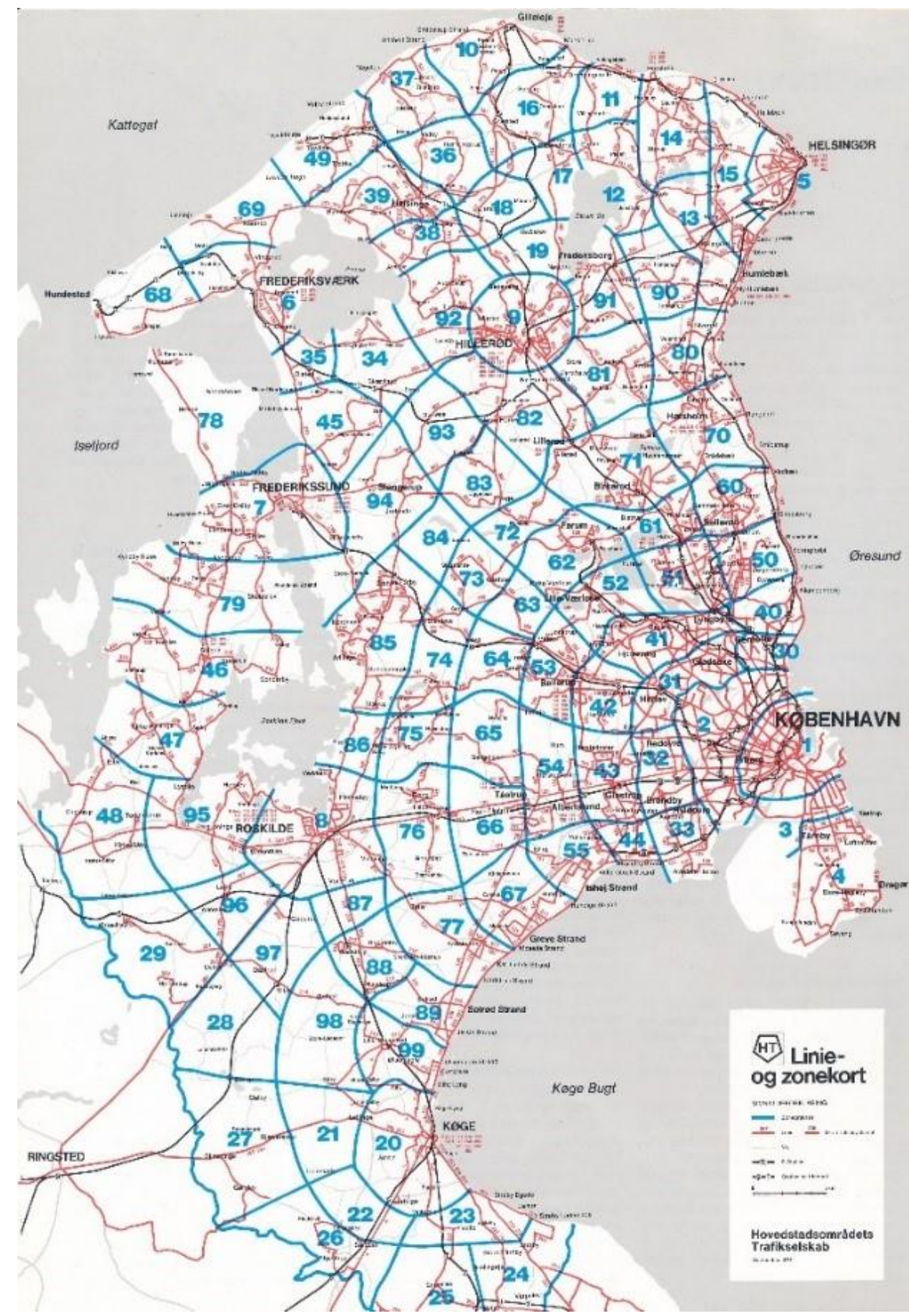

HT's linjenet og takstsystem 1976 (J.nr. 121.1 II, Sekretariatet [Frederiksberg Stadsarkiv A 10) 
Fra slutningen af 70'erne og i det meste af det følgende årti udbyggedes driften på landevejsruterne, der betjente landdistrikterne i Frederiksborg og Roskilde amtskommuner eller forbandt de større byer i de to ydre hovedstadsamtskommuner samtidig med, at der her udlagdes et større antal særlige regionale trafikterminaler ved krydsningspunkter for regionale bus- og jernbanelinjer; i de dele af hovedstadsmetropolen med tæt ved liggende sommerhusbyer således i Skibby, Frederikssund, Frederiksværk, Hundested, Helsinge, Græsted, Rågeleje og Gilleleje. I samme områder gennemførtes samtidig telebuskørsel, der, baseret på kontakter med lokale vognmænd eller taxiselskaber og ud fra en fastlagt netstruktur, gennemførte telefonbestilte kørsler i mindre busser i tyndt befolkede dele af hovedstadsmetropolens yderområder.

Med Kollektiv Trafikplan 1989 blev nogle af de tværgående buslinjer yderligere udbygget dels mellem Roskilde og Hillerød, hvor der skulle kunne ske direkte omstigning til de tværgående banestrækninger: Hillerød-Helsingør og Roskilde-Køge, dels fra Frederikssund gennem Hornsherred via Hvalsø og Borup til Køge, dels mellem Helsingør og Frederiksværk. Fra de ydre stationer i forstadsbăndene og købstæderne skulle sidebaner eller regionale busser desuden skabe forbindelse til de uden for liggende pendlersatellitbyer og dermed hovedstadsmetropolens fjerne åbne opland. Her ude skulle tillige udlægges et lokal busnet mellem de små bysamfund, herunder sommerhusbyerne, og de kommunecentre, i reglen en større pendlersatellitby, som Regionsplan 1989 opperede med i denne del af metropolen, og herfra med videre forbindelse til nærmeste nabokommunecenter eller de regionale udflugtsmål, som indgik i denne regionsplans oplevelsesrige landskaber. Således en afgørende kobling mellem Hovedstadsrådets sektorplanlægningen af det åbne lands anvendelse og dets kollektive trafikplanlægning..$^{59}$
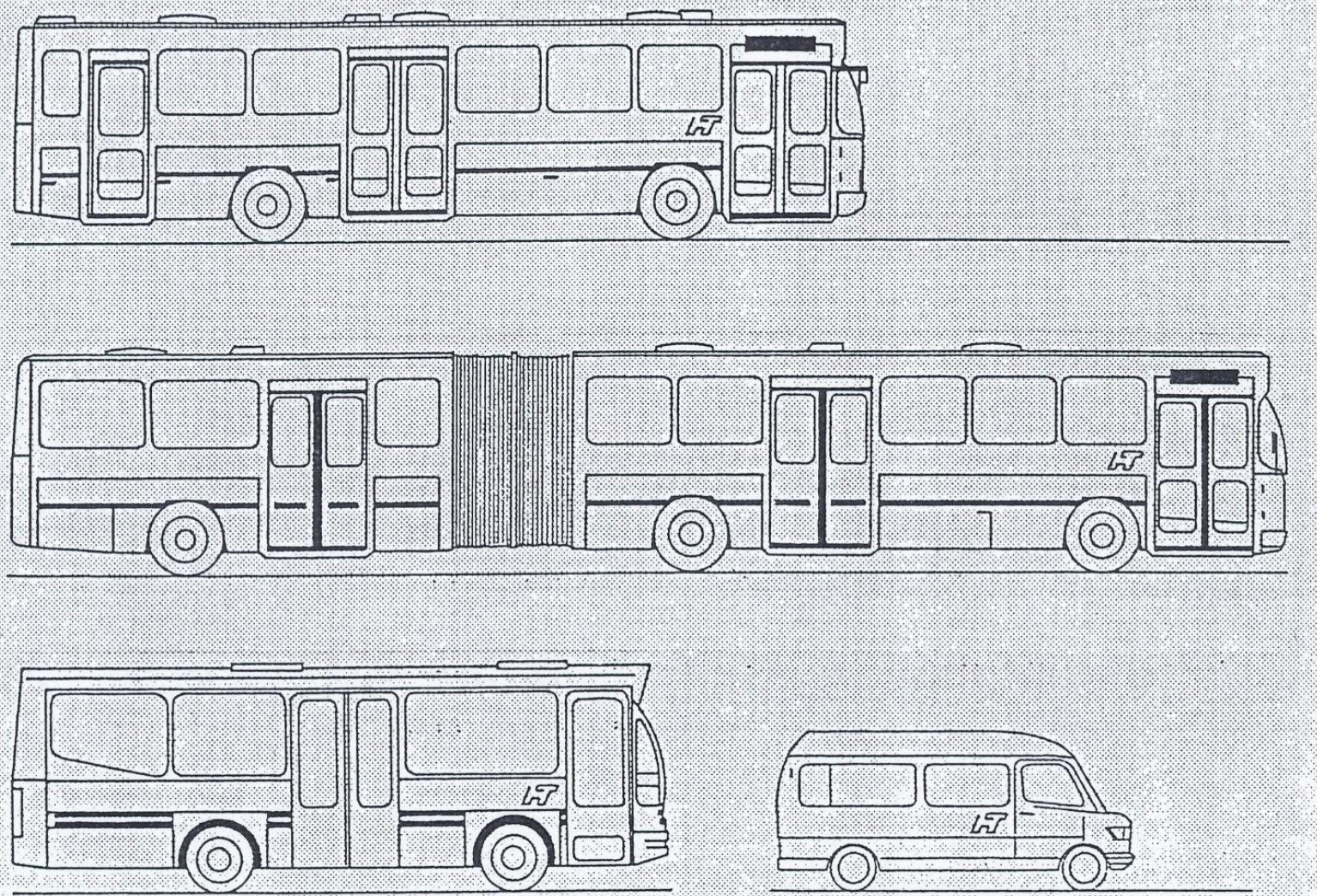

I slutningen af 80'erne udarbejdede HT udkast til indkøb af busser, der var tilpasset de forskellige betjeningsbehov, der var $i$ hovedstadsmetropolen. I metropolens åbne land indsatte de store busser og de lange ledbusser, de to øverst stående, på de gennemgående regionale ruter, mens de mindre, de to nederst stående, på mere lokale ruter (Kollektiv Trafikplan 1989, J.nr. 89-11332-2/I, Sekretariatet, Frederiksberg Stadsarkiv) 
Blok- og fjernvarmeområder

$\equiv 18$ kommuner forsynet fra regionalt net

Varmegrundlag

- 0 - $50 \mathrm{TJ} / \mathrm{a} r$

- 50 - $200 \mathrm{TJ} / \stackrel{a}{\mathrm{r}}$

$200-1000 \mathrm{TJ} / a ̊ r$

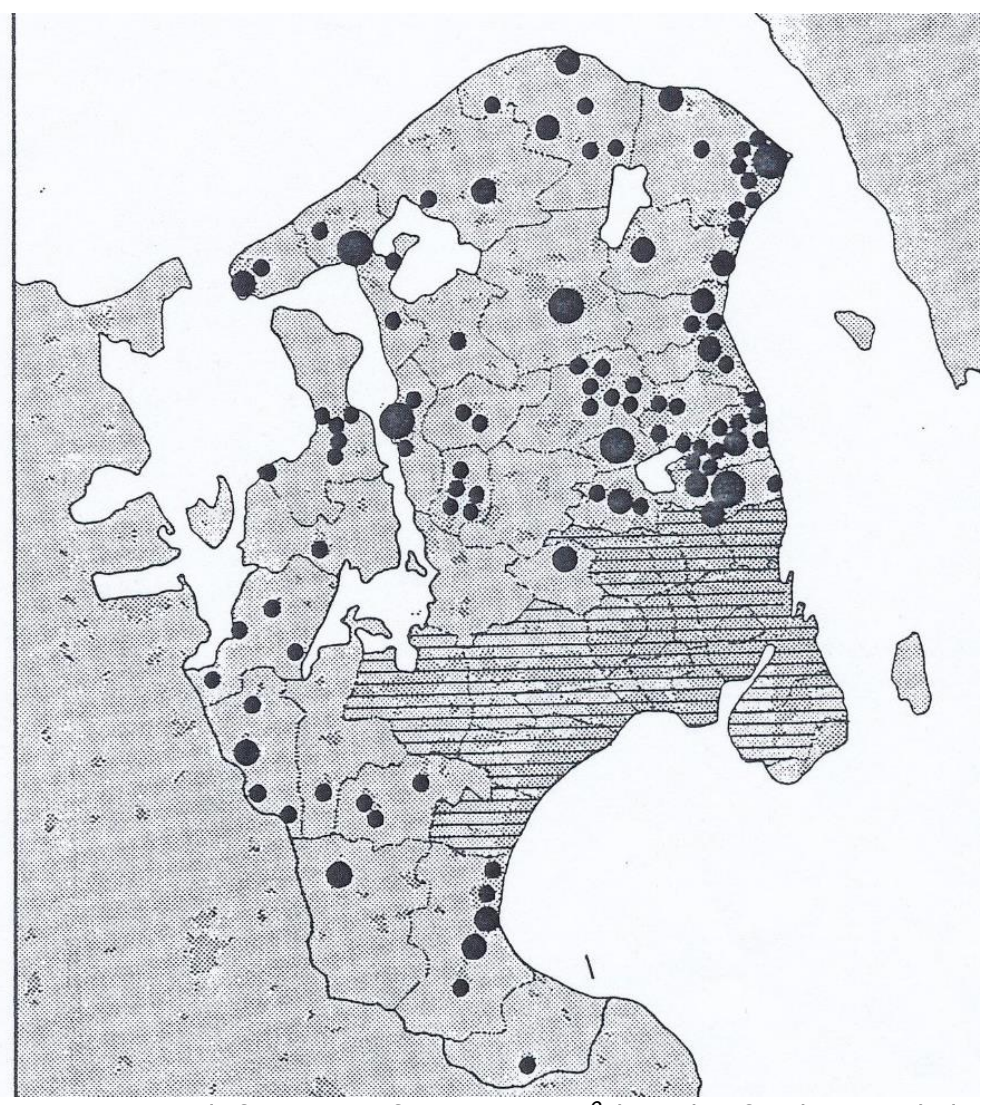

Hovedstadsrådets regionale varmeplan 1988. Skraveret: Regionalt fjernvarmeforsyningsområde. Uden for dette: Lokalisering af og kapacitet på decentrale kraftvarmeværker og forbrændingsanlæg samt mere lokale fjernvarme-og blokvarmecentraler (Regional Varmeplan 1988, Hovedstadsrådet, 1988)

\section{Regionalforsyning}

Selv om Hovedstadsrådet i sin regionale forsyningsplanlægning i den sidste efterkrigstid kalkulerede med en betydelige stigning i el- og vandforbruget i hovedstadsmetropolens sommerhusbyer, som følge af den stærkt forøgede installation af vand- og elbrugende husholdningsudstyr $i$

sommerhusbyggeriet, blev disses elektricitetsforsyning ikke direkte berørt af rådet sektorplanlægning på området. Elektricitetsforsyningen blev således som hidtil overladt til NESA, og i henseende til Hovedstadsrådets regionale retningslinjer for placering og linjeføring af produktionsværker og højspændingskabler og- ledninger fik disse kun perifer betydning i Hornsherred. Her udlagdes således efter Hovedstadsrådets lokaliseringsretningslinjer en 400 kv højspændingsmasteføring fra Kyndbyværket på Hornsherreds vestkyst ned gennem midten af halvøen og med videre forbindelse til Asnæsværket ved Kalundborg Fjord, mens et atomkraftværk ved Sømmer på Hornsherreds vestside, der ville have forårsaget særlig indskrænkning i arealanvendelsen i en radius af $10 \mathrm{~km}$ fra værket, udgik af planlægningen i løbet af 80 'erne.

Selv om de dele af hovedstadsmetropolens åbne land, hvor sommerhusbyerne var lokaliseret til lå uden for Københavns Kommunes og Sjælsø-værkets vandmonopol, og kommunerne dermed var selvforsynende med vand, fik Hovedstadsrådets regionale vandindvindingsplanlægning her en vis indflydelse. Kommunerens stedlige vandingsvindingsvolumen og vandpriser ansattes således i denne sektorplanlægning, der tillige udpegede områder, hvor der ikke måtte gives nye vandindvindingstilladelser, og eksisterende vandindvindingstilladelser ikke kunne udvides. Disse udgjorde såkaldte kerneområder og spredningskorridorer for plante- og dyreliv og særlige naturområder, hvor der af hensyn til vandgennemstrømingen i vådområder og dermed af hensyn til plante- og dyrelivet ikke måtte foretage yderligere vandindvinding. 


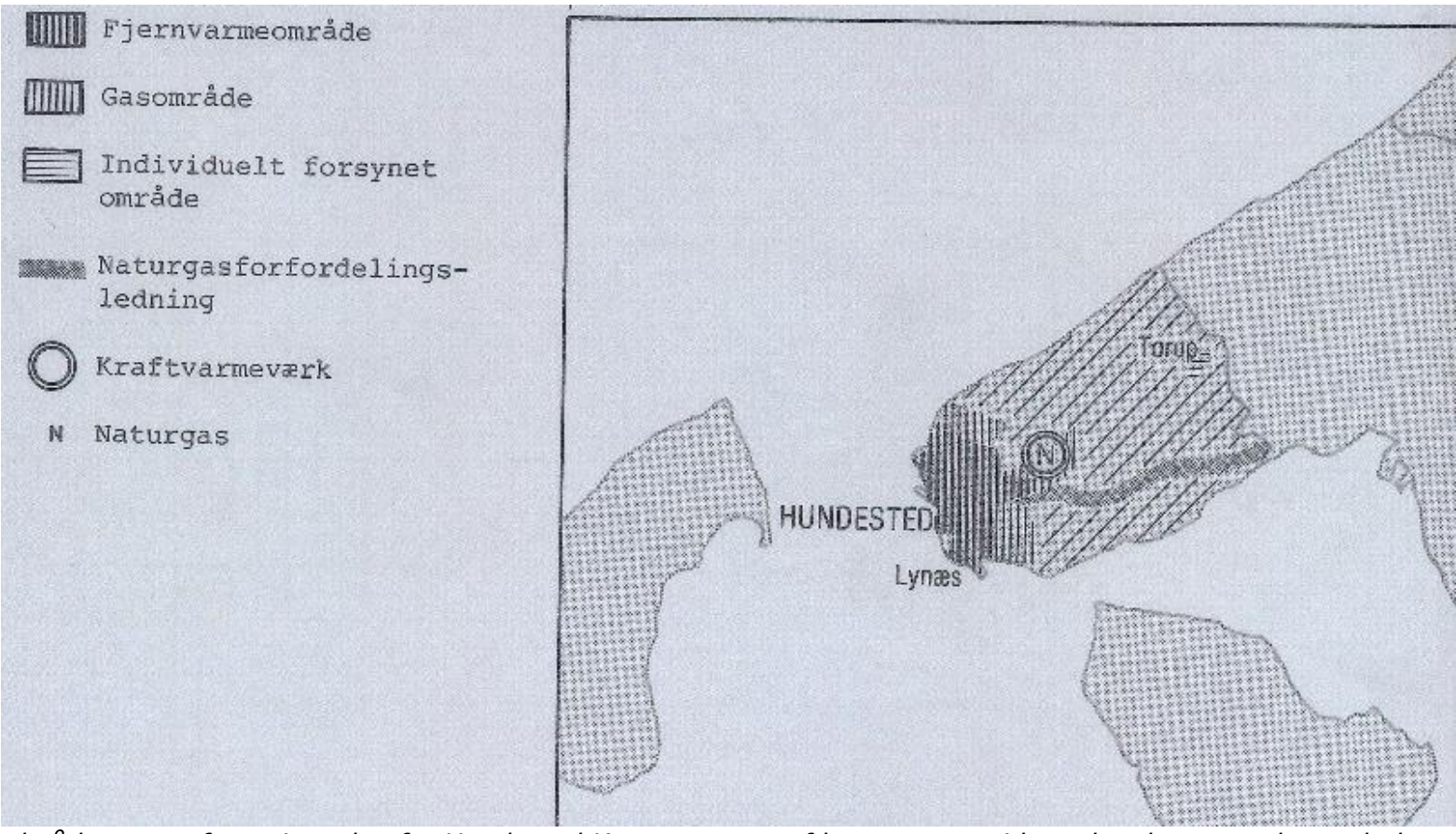

Hovedstadsrådet varmeforsyningsplan for Hundested Kommune- en af kommunerne i hovedstadsmetropolens yderkant $i 1988$. Hovedparten af kommunens sommerhusbyer lå i områder, hvor planen forsat gav mulighed for individuel varmeforsyning (Regional Varmeplan 1988, Hovedstadsradet, 1988)

I de områder hvor sommerhusebyerne var lokaliseret, gjaldt disse bestemmelser i det nordligste dele af Hornsherred, et midt liggende strøg på halvøen og i dens sydligste del samt områder i kystbaglandet ved dele af både Kattegatkysten og østsiden af Roskilde Fjord. Kommuner, der her ikke kunne indvinde tilstrækkelig vand på eget område, indgik efter Hovedstadsrådets anvisninger og medvirken leveringsaftaler med nabokommunerne. Med sin vandindvindingsplanlægning sikrede Hovedstadsrådet dermed, at den del af sommerhusbyernes vandforsyning, der kom fra kommunale vandværker, var tilstrækkelig uden, at den belastede de knappe grundvandsforekomster og det naturmiljø, der stod centralt i rådets sektorplanlægning af det åbne lands anvendelse. ${ }^{60}$

Efter at Hovedstadsrådets varmeplanlægning efterhånden kom til at omfatte størsteparten af hovedstadsmetropolen, stod i den sidste del af $80^{\prime}$ erne alene dens yderområder udenfor samtidigt med, at der blev behov for en endnu mere rationel anvendelse af de varme- og energiressourcer, som i højere grad kunne opnås ved en mere hensigtsmæssig udnyttelse af naturgassen, andre energikilde og affaldsforbrændingsanlæggene og ved etablering af et større antal decentrale kraftvarmeværker. Anlæg og værker, der efter Hovedstadsrådets Regional Varmeplan 1988 kom til at indgå i det under opbygning regionale fjernvarmenet i hovedstadsmetropolens indre del og de mindre fjernvarmebaserede områder i metropolens regionalt naturgasforsynede område. Med Regional Varmeplan 1988 blev de 10 kommuner, der i hovedstadsmetropolens yderområde hidtil havde ligget uden for Hovedstadsrådets fjernvarme- og naturgasområder, endelig integreret i rådets samlede varmeplan for hele hovedstadsmetropolen. Kommunerne, der tillige rummede størsteparten af hovedstadsmetropolens sommerhusbyer, omfattede Hundested, Frederiksværk, Helsinge, GræstedGilleleje, Skævinge, Jægerspris, Skibby, Bramsnæs, Hvalsø og Vallø.

For hver af disse fastlagde Regional Varmeplan 1988 meget detaljerede planrammer for: Dels fjernvarmeområder, hvorfra varme tilvejebragtes af decentrale kraftvarmeværk, hvor energien kom fra naturgas, halvfyring, industrioverskudsvarme, som f.eks. Stålvalseværket i Frederiksværk, lokale fjernvarme- og blokvarmecentraler, lokale fjernvarmeområder, i hovedreglen i stedlige stationsbyer og købstaden Frederiksværk. Dels naturgasopvarmede områder omfattende disse byers yderdistrikter og større landsbyer, hvor naturgasnettets hovedtransmissionsnet gik igennem, og hvortil der kunne opnås tilslutning. Dels områder baseret på individuel varmeforsyning, hvor Hovedstadsrådet lagde op 
til, at kommunerne skulle træffe beslutning om omlægninger til alternative opvarmningsformer, end ved olie og el, i form af anvendelse af lokale ressourcer, f.eks. træbrænde, flis, briketter, halm og biogas.

Skønt Hovedstadsrådets varmesektorplanlægning repræsenterede et blandt mange af dets betydeligste regionale landvindinger, lå langt størsteparten af hovedstadsmetropolens sommerhusbyer så langt fra de dele af dens åbne land, som blev omfattet af varmeforsyning gennem fjernvarme eller naturgas, og blev således alene omfattet af planlægnings retningslinjer for områder for individuel varmeforsyning. Kun et mindretal tilsluttedes săledes et lokalt naturgasnet, og alene sommerhusbyerne omkring Gilleleje og sommerhusbyen Ejby Strand i Hornsherred blev tilsluttet det lokale fjernvarmenet i henholdsvis den store stations- og pendlersatellitby ved Kattegatkysten og landsbyen Ejby. ${ }^{61}$

\section{Den regionale spildevandsafledning}

Mens der allerede i forbindelse med planlægningen og den senere udbygning af forstadsbæltet ned langs den sydlige del af Køge Bugt var etableret en fælleskommunal spildevandsafledningsordning via en hovedkloak og rensningsanlæg ved Ishøj, Mosede og Solrød Strand, sluttede i slutningen af 70 'erne de syd for liggende Køge og Skovbo kommuner sig sammen om en fælles udledning via I/S Køge-egnens Rensningsanlæg i Køge, ligesom der gennemførtes en samlet udledning fra hele Vallø Kommune; hovedstadsmetropolens sydligste. Herudover tilvejebragtes endelig en mere samlet ordning af spildevandsforholdene i dele af Nordsjælland. Helsingør Kommune etablerede således med udløb i Øresund og Kattegat tre afledningssystemer med biologisk rensning for spildevandet fra Helsingør by og Espergærde samt fra Hornbæk og Hellebæk. For hele Frederiksværk Kommune tilvejebragtes samtidig en samlet kemisk-biologisk renset udledning i Kattegat. Spildevandudledning fra kommuner med sommerhusbyer på Nordstevns samt på dele af Kattegatkysten og den nordlige del af Roskilde Fjords østside fik på den måde en efter samtiden fuldt tilfredsstillende spildevandsafledning, der svarede til de sidste efterkrigstidsårtiers omfattede fælleskommunale spildevandsafledningsordninger i hovedstadsmetropolens centrale dele.

Ordninger, der ikke kom til at omfatte Farum Kommune, tilsvarende forstadskommuner i den nordøstlige del af Nordsjælland og de øvrige dele af hovedstadsmetropolens ydre åbne land. Hovedstadsrådet forsøgte her ad en række omgange forgæves at få etableret fælleskommunale afledningsordninger med afskærende og dermed samlede kloaksystemer med få udledningssteder fra centrale kemisk-biologiske rensningsanlæg på tværs af kommunegrænserne, men måtte indskrænke sig til ved godkendelse af lokalkommunale spildevandsplaner at tilvejebringe mere ordnede forhold. I form af forbud mod udledning af urenset spildevand og krav om dels nedlæggelse af mekaniske rensningsanlæg og til erstatning af disse etablering af decentral biologisk-kemisk rensning af spildevandet, dels en samling af de mange afløb til et mindre antal udledningssteder opnået gennem lokale afskærende kloaksystemer.

En fremgangsmåde, som rådsforvaltningen tillige tog i anvendelse ved ordningen af spildevandsforholdene i hovedstadsmetropolens yderste åbne opland, hvor netop sommerhusbyerne var lokaliseret, og der i starten af den sidste efterkrigstidsperiode var sket udledning af urenset eller mekanisk renset spildevand til åløb, søer, Kattegat, Roskilde fjord og Isefjorden med en kritisk vandforurening til følge. Ved Hovedstadsrådets godkendelse af kommunale spildevandsplaner og i takt med kloakering af satellitbyerne og dele af sommerhusbyerne forøgedes antallet af kemiske eller biologisk rensningsanlæg i den sidste efterkrigstid fra henholdsvis 143 og 113 til 169 og 124 i Frederiksborg og Roskilde amtskommuner.

En indsats, der netop under Hovedstadsrådets overordnede regionale beføjelser ikke blot førte til, at spildevandsbelastningen fra de kloakerede sommerhusbyer også inddæmmende, men nok så afgørende bevirkede, at vandkvaliteten i sø-, å- og kystomrăder i 
hovedstadsmetropolens yde åbne opland blev højnet i forhold til de uacceptable tilstande, der her mange steder gjorde sig gældende i starten af perioden. En afgørende forudsætning for opfyldelsen af den meget centrale rekreative betydning, som det åbne land udgjorde i Hovedstadsrådets sektorplanlægning for det åbne lands anvendelse. Tilbage stod dog de regionsudfordringer, som de ikke kloakerede sommerhusbyer udgjorde i forhold til grundvandsnedsivning og ikke mindst, at spildevandet fra det store antal kemiske eller biologiske rensningsanlæg fortsat i udledtes til åløb, søer og fjorde, og ikke udgjorde den mest optimale spildevandshåndtering. ${ }^{62}$

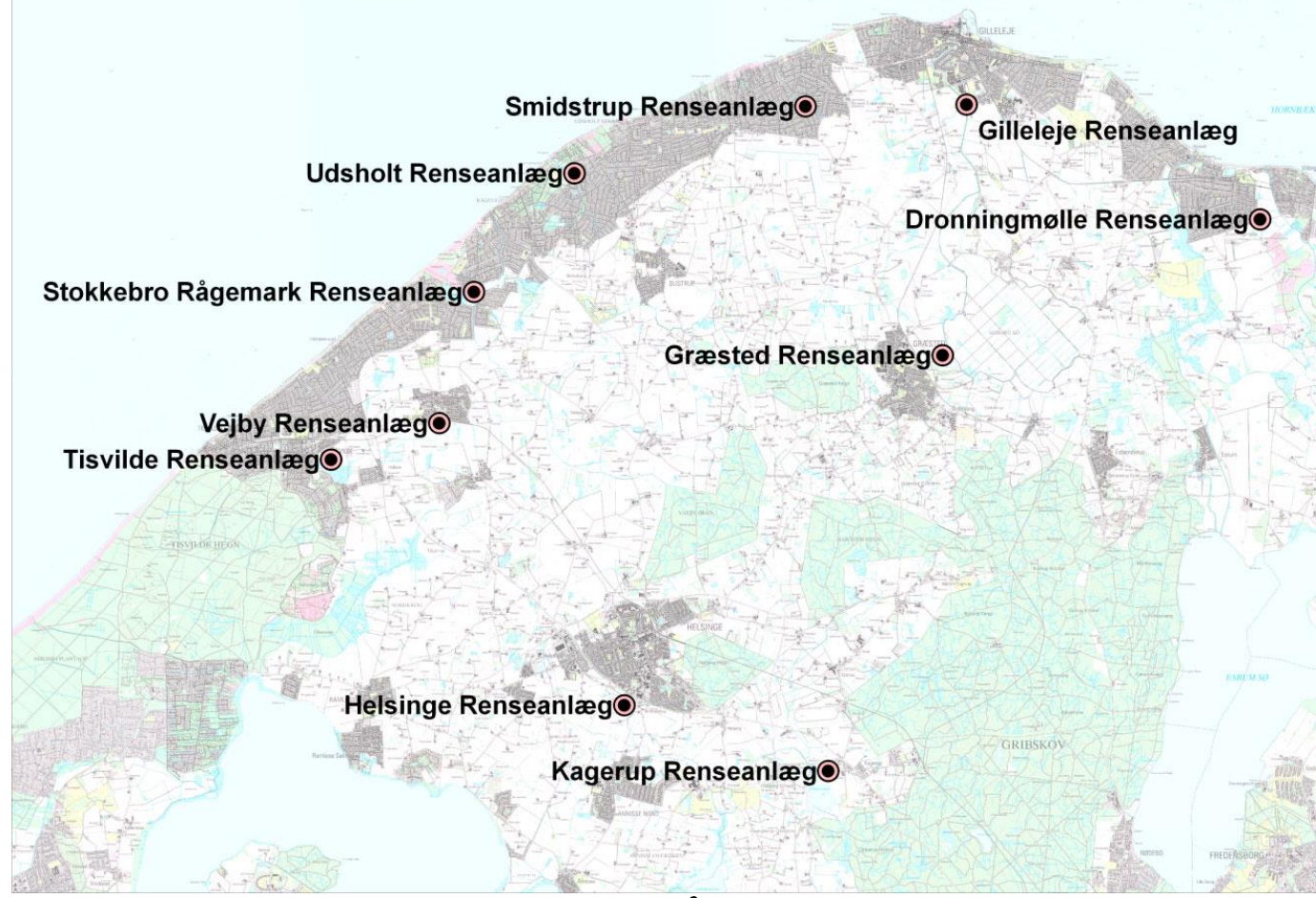

Da hovedstadsmetropolens ydere kommuner, og dermed også dem med store sommerhusbyer, ikke i den sidste efterkrigstid blev omfattet af de fælleskommunale spildevandsordninger, som i de indre dele af metropolen blev resultatet af Hovedstadsrådets sektorplanlægning pa spildevandsområdet, blev følgen, at spildevandets rensedes via det store antal decentrale rensningsanlæg, der udledte til vandløb, søer, fjorde og de abent hav. F.eks. overtog nuværende Gribskov Kommune således i 2007 ikke mindre end 10 rensningsanlæg fra forgængerkommunerne Græsted-Gilleleje og Helsinge. Først i 2020-2022 nedlægges de syv rensningsanlæg ved Kattegatkysten, hvorefter spildevandsafledningen fra dennes sommerhusbyer og pendlersatellitbyer samlet ledes til det stærkt udvidede rensningsanlæg i Gilleleje, hvorfra det rensede spildevand af en $400 \mathrm{~m}$ lang ledning ledes ud $i$ havet. Endelig en forsvarlig spildevandsafledning, som de mere centrale dele af hovedstadsmetropolen havde fået 40-60 àr før.(https://www. gribvand.dk/cgi-

bin/uploads/media/pressemeddelelse/Ny\%20havledning\%20sikrer\%20badevandet\%20i\%20Gilleleje.pdf)

Havde håndteringen husholdningsaffald i hovedstadsmetropolens sommerhusbyer hidtil haft en nærmest anarkistisk karakter, førte Hovedstadsrådets affaldsplanlægning også til signifikante resultater. Kommunerne blev således efter Hovedstadsrådets bindende retningslinjer pligtige til at udarbejde en affaldshåndteringsplan, ligesom rådet opstillede de regionale rammer for håndteringen af de samlede affaldsmængder. Med mindre forbrændingsanlæg i Gilleleje og Frederikssund var det fælleskommunale affaldshåndteringsselskab I/S AFAV blevet oprettet i midten af 70 'erne, og betjente med lossepladser i Frederiksværk og Græsted-Gilleleje kommunerne i de nordligste og vestlige dele af det nordlige Nordsjælland og dermed også en betydelig del af hovedstadsmetropolens sommerhusbyer. Med tilslutning af Skibby Kommune til I/S AFAV's betjeningsområde og Bramsnæs Kommune til I/S KARA's, der med udgangspunkt i forbrændingsanlægget i Roskilde opperede i den ydre sydlige dele af hovedstadsmetropolen, blev samtlige af dens sommerhusbyer i den sidste efterkrigstid også 
omfattet af den regionale affaldshåndteringsordning, som Hovedstadsrådet lagde de regionale rammer for $\mathrm{i}$ hele metropolens område. ${ }^{63}$

\section{Det regionale sygehustilbud}

I midten af det 20. århundrede var hovedstadsmetropolens forstæder allerede vokset ind i den sydøstlige del af Frederiksborg Amtskommune, og i den første efterkrigstid bredte forstadsdannelserne dybere ind i både denne amtskommune og Roskilde Amtskommune. Samme med den parallelt løbende byvækst omkring købstæderne i købstadsringen og dannelsen af pendlersatellitbyer uden for blev disse hidtil ydere dele af hovedstadsmetropolen både erhvervsmæssigt og demografisk en integreret del af metropolen, og opnåede en befolkningsforøgelse på 74 procent i 50- og 60'erne. Med denne befolkningstilvækst og de samtidig meget store områder med sommerhusbyer, der i ferieperioder og weekends tillige pressede de to ydre hovedstadsamtskommuners hidtil provinsorganiserede sygehusvæsener, stilledes disse efterhånden over for betydelige udfordringer.

Selv om både Frederiksborg og Roskilde amtskommuner med egne sygehusudbygninger og indgåede indlæggelsesaftaler med sygehuse og hospitaler i den øvrige del af hovedstadsmetropolen havde forsøgt at tilvejebringe et $\varnothing$ get lokalt sygehusudbud, kom de to amtskommuner som følge af en manglende regionalt planlægning og koordinering på sygehusområdet ikke op på samme niveau som i den øvrige del af metropolen, og repræsenterede dermed nogle af de udfordringer, der kendetegnede dennes regionale sygehusstruktur. ${ }^{64}$ Målt i det samlede til rådighed stående antal sengepladser pr. 1.000 indbyggere i 1970, havde hovedstadens kommunale hospitalsvæsener således opbygget et væsentlig større hospitalsudbud end resten af hovedstadsmetropolens kommunale sygehusvæsner og Sundhedsstyrelsens norm. Københavns og Frederiksborg Amtskommuners sygehusudbud lå ganske vist på samme niveau, men næsten 50 procent under hovedstadens og 23 procent under Sundhedsstyrelsens normtal. I bunden placerede Roskilde Amtskommune sig med et sygehusudbud, der var knap to tredjedele mindre end hovedstadens og 43 procent under Sundhedsstyrelsens norm.

Forskelle, der også gjorde sig gældende på de kliniske hovedområder, hvor Københavns hospitalsvæsen som følge af byens befolkningssammensætning havde et markant større udbud på det langtidsmedicinske område og hovedstadens to kommunale hospitalsvæsner på det medicinske og kirurgiske, mens Københavns og Frederiksborg amtskommuner lå på samme niveau, men signifikant under hovedstaden og noget under Sundhedsstyrelsens normtal. Også på dette punkt lå Roskilde Amtskommune i bunden i særlig grad i forhold til hovedstaden, men tillige væsentligt under Sundhedsstyrelsens norm. ${ }^{65}$

Skønt hovedstadsmetropolens kommunale sygehusvæsener i den første del af 70 'erne tog initiativ til en højere grad af sygehusplanlægning og til en vis form for regional koordination af de sygehusmæssige dispositioner, blev det først under indtryk af en kombination af Hovedstadsrådets grovskitse til en regional sygehusplan fra 79, de amtskommunale sygehusplaner, rådets overordnede sygehusplan fra 82 og talrige statslige centraladministrative indgreb, at metropolens sygehusvæsen både i enkelte hovedstadskommuner og -amtskommuner og regionalt blev underlagt mere vidtgående regionsplanrammer. Rammevilkår, der i den sidste efterkrigstid førte til en signifikant opgradering af de ydre amtskommuners sygehusener, der indebar, at borgerne og sommerhusbeboerne her fik et sygehustilbud, der kom i næreheden, af det der blev givet i hovedstadsmetropolens indre del.

Allerede i 1970 havde et embedsmandsudvalg i Frederiksborg Amtskommune i 1970 lagt op til en betydelig centralisering af sygehusbehandlingen, idet amtskommunens $\varnothing$ vrige sygehuse skulle afvikles over en årrække. Som konsekvens af, at folketallet op gennem den sidste efterkrigstid ikke forøgedes så voldsomt, som embedsmandsudredningen havde anslået, blev udbygningen af amtskommunens sygehusvæsen ikke så gigantisk, som embedsmændene havde bragt i forslag, ligesom der var politisk var modstand mod de foreslåede stærke centraliseringer, idet der herfra var et ønske om fortsat at opretholde et mere decentralt behandlingstilbud. 
Følgelig opførte Frederiksborg Amtskommune i 1976 i Helsingør et nyt sygehus i byens yderdistrikt med 170 sengepladser, mens det gamle amts- og bysygehus i Frederikssund i 1985 erstattedes med et nyt sygehus med 200 sengepladser et godt stykke uden for byen. Med denne kapacitet kunne sygehuset i Frederiksværk, der siden slutningen af 50' erne alene havde varetaget ortopædkirurgi, nedlægges. Til gengæld kom specialamtssygehuset i Esbønderup med udvidelser i 70 'erne til at omfatte 100 sengepladser, mens Usserød Amtssygehus uden større udvidelser fortsatte som lokalsygehus og indgik i et funktionelt samvirke med sygehuset i Helsingør. Sammen med en nyopført stor sengebygning på centralsygehuset i Hillerød kunne Frederiksborg Amtskommune opdele sit område i de tre optageområder, som der blev lagt op til i sygehusplanlægningen i forbindelse med Hovedstadsrådets overordnede sygehusplan. Amtskommunen opnåede tillige i vid udstrækning selvforsyning for så vidt de sygehusmæssige lokalfunktioner og en samlet forøgelse af mængden af sengepladser på 12 procent i perioden 1972-1990.

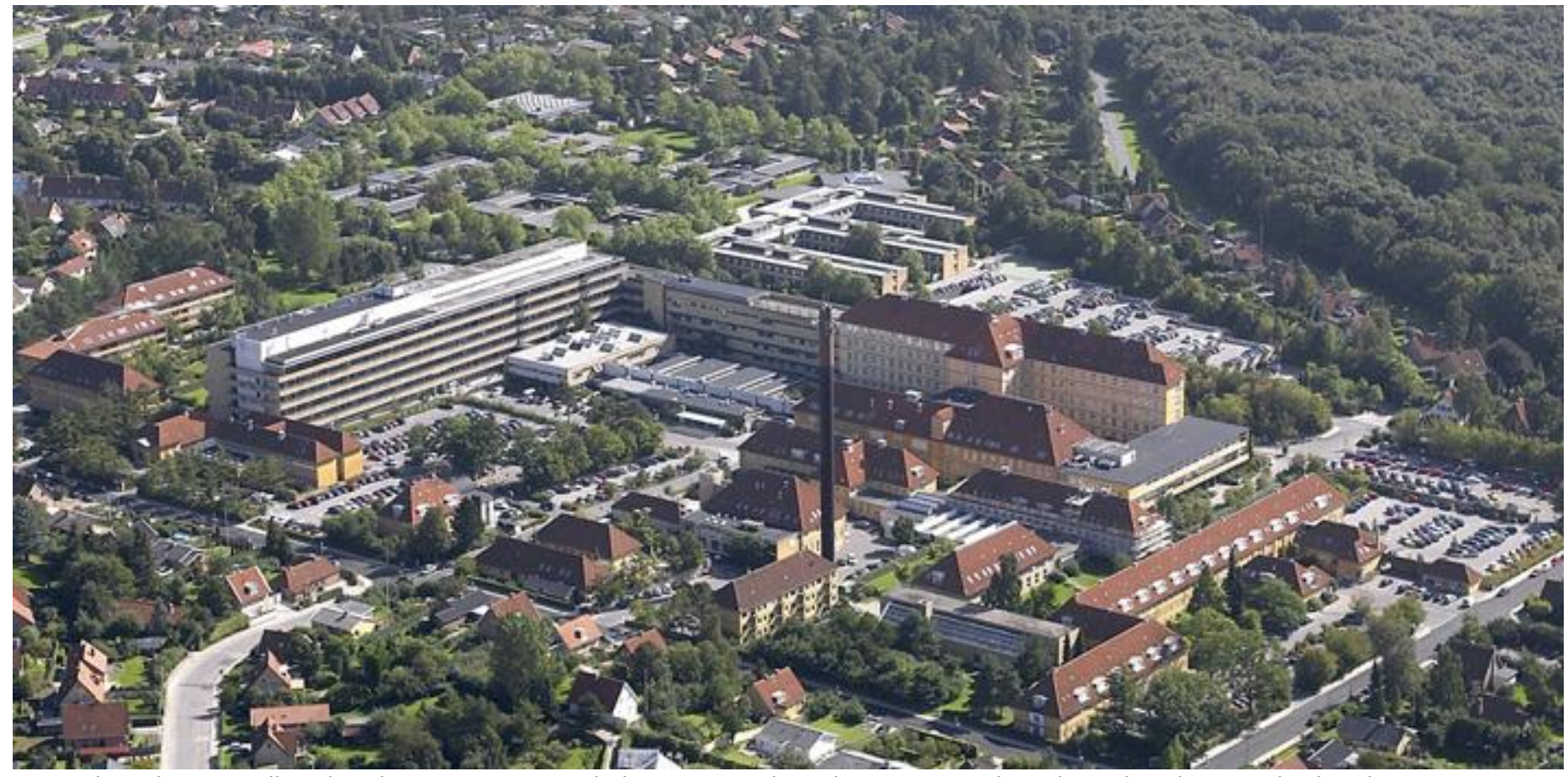

Centralsygehuset i Hillerød omkring 1990. De gule bygninger udgør det nye centralsygehus, der $i$ byens yderdistrikt $i$ 1943 erstattede det ældre amts- og bysygehus i nærheden af banegården. Det store antal øvrige bygninger blev $i$ hovedsagen opført i den sidste efterkrigstid (Region Hovedstaden)

Også i Roskilde Amtskommune havde et embedsmandsudvalg haft visioner om sygehusplanlægning, der som følge af manglende arealer til udvidelse af centralsygehuset i Roskilde rummede forslag til et nyt sygehus i Køge med 300 sengepladser og et stort Køge Bugt-sygehus med 1.000 senge. Men også her måtte de storstilede planer reduceres, og op gennem den sidste del af efterkrigstiden blev det alene til en ny fløj på sygehuset i Roskilde med knap 100 senge og et helt nyt sygehus i Køge. Fra starten disponeret til 300 sengepladser, men med udvidelsesmuligheder til op til 500 senge. Den højere grad af selvforsyning med lokale sygehusfunktioner og den opdeling af amtskommunens område i lokale optageområder, som Roskilde Amtskommune havde lagt op til i sin sygehusplan i forbindelse med Hovedstadsrådets overordnede sygehusplan, kunne dermed realiseres. Med den betydelige udbygning af Roskilde Amtskommunes sygehusvæsen opnåedes op gennem den sidste efterkrigstid en forøgelse af den samlede sengemængde på 43 procent. Det var den højeste tilvækst i hovedstadsmetropolen, men den var tvingende nødvendig i forhold til det betydelige efterslæb, som amtskommunens sygehusvæsen omkring 1970 havde i forhold til den $\varnothing$ vrige del af metropolen. ${ }^{66}$ 


\section{Delkonklusion}

Mens den første efterkrigstid blev forbundet med omfattende sommerhusbydannesler i udkanten af hovedstadsmetropolens åbne land, ændredes forudsætningerne sig herfor markant i de sidste efterkrigsårtier. Væksten i sommerhusbyggeriet fladede voldsom ud samtidig med, at der gennem et særligt regionalkommunalt organ for hele hovedstadsmetropolen, Hovedstadsrådet, tilvejebragtes en række regionale rammebetingelser, der forbedrede dens funktion som en byregion, og tillige inddæmmende de omfattede regionale udfordringerne, som var udsprunget af sommerhusbydannelserne.

\section{Sommerhusbølgen flader ud}

Blev 80,8 procent af efterkrigstidens samlede sommerhusvolumen i hovedstadsmetropolen på 40.000 nye sommerhuse rejst i den første efterkrigstid, opførtes alene de resterende 19,2 procent i dennes sidste periode. Med opførelsen af i gennemsnit 1.427 sommerhuse huse pr. år i den første efterkrigstid betegnede den sidste efterkrigstid med årligt 487 nye sommerhuse pr. år et kraftigt tilbageslag for sommerhusbyggeriet.

Med afsæt i hovedspørgsmål A har denne bog påvist, at den sidste efterkrigstids tilbagevende økonomiske lavvækstår og hovedstadsmetropolens deraf følgende stagnerende udvikling blev afgørende for periodens stærkt aftagende sommerhusbyggeri. Et aspekt, som hverken på nationalt eller regionalt plan er blevet taget op af den kulturhistoriske og kultursociologisk inspirerede litteratur, som har behandlet denne periodes sommerhusbyggeri.

\section{Hovedstadsmetropolens stagnation}

Havde hovedstadsmetropolen i den første efterkrigstid været kendetegnet af en massiv befolknings- og bymæssig tilvækst, reduceredes dens folketal op gennem den sidste efterkrigstid med 2 procent. Hovedstadsmetropolen fastholdt ganske vist et folketal på over 1,7 mio., men befolkningsudvikling indikerede, at dens altdominerende rolle i det dansk bysystem blev svækket i disse årtier.

Mens den bebyggelsesmæssige opfyldning af de indre forstæder i Københavns Amtskommune i perioden alene førte til samme fald i folketallet som i hovedstadsmetropolens som helhed, mistede hovedstaden således næsten 205.000 indbyggere. Et fald i dens befolkning på næsten 30 procent genereret af en i forhold til den første efterkrigstid voldsommere afvandring og det stigende fødselsunderskud, som fulgte af unge og yngres udflytning fra hovedstaden og den stadig større gruppe af ældre over 65, der blev tilbage. At hovedstadsmetropolens samlede folketal i den sidste efterkrigstid, trods hovedstadens massive befolkningstilbagegang, alene kom til udvise en svagt vigende tendens, var betinget af en samlet befolkningstilvækst på mere end en tredjedel i de ydre amtskommuner, hvor en væsentlig del af tidens nye bolig- og erhvervsbyggeri blev henlagt.

En dermed tiltagende urbaniseringsproces i hovedstadsmetropolens ydre dele, som trods stagnation og krise var med til at forstærke det urbane pres og dermed behovet for at søge ud af den stadig fortættede metropol med dens forsatte hektiske trafik, tiltagende miljøbelastninger og forcerede arbejdsliv. Et behov, der blev muligt at tilfredsstille med den sidste efterkrigstids yderligere udvidelse af den arbejdsfri tid. Fra 1985 blev den femte ferieuge således en realitet samtidig med, at den ugentlige arbejdstid i 1990 nåede ned på 37 timer. At det ikke i samme tiltagende omfang som i den første efterkrigstid blev et sommerhus, der gav mulighed for opnå et rekreativt ferie- og fritidsliv uden for hovedstadsmetropolen, blev betinget af de forandrede samfundsøkonomiske rammevilkår, som satte sig igennem i den sidste del af efterkrigstidsperioden. 


\section{Lavvækst}

Ud over den stagnerede befolknings-, bebyggelses- og erhvervsmæssigeudviklingstakt, der i den sidste efterkrigstid i hovedstadsmetropolen lagede begrænsninger for den videre udbredelse af sommerhusbyer, fulgte virkningerne af tilbagevendende økonomiske kriser i de første år af 70'erne, gennem resten af årtiet og i 80' erne, som udsprang af afvikling af dele af den traditionelle arbejdsintensive industri. En konsekvens af en svækket konkurrenceevne skabt af et højt produktionsomkostningsniveau og forstærket af priskonkurrence som følge af øget økonomisk globalisering med produktionsudflytninger til lavlønsområder i Europa og den tredje verden.

Krisrene manifesterede sig i en langt svagere økonomisk vækst end i den første efterkrigstid, år med negativ vækst og realindkomstnedgang og dermed tillige en svagere vækst i rådighedsbeløb og samlet konsum. Med den heraf følgende mindre vækst i det private forbrug forrykkedes forbrugssammensætningen på ny. Selv om andelen af basale livsfornødenheder, fødevarer, beklædning m.m., fortsat kom til at udgøre en mindre andel i det samlede forbrug, øgedes i nogle af de værste kriseår bolig- og opvarmningsudgifternes andel som følge af et stigende renteniveau og de kraftigt stigende oliepriser, der tillige var bidragende til tidens højere produktionsomkostninger. På nær andet konsum, førte det mindre økonomiske råderum og de højere bolig- og opvarmningsudgifter, til at de øvrige poster i forbrugssammensætning kom til at indgå med mindre andele i perioden. Mest markant for boligudstyr og fritid m.m., hvorunder også sommerhus nu henregnedes.

I lyset af den sidste efterkrigstids krise prioriteredes helårsboligen og varige forbrugsgoder i denne således højere end en sekundær fritids- og feriebolig. Væksten i sommerhusbyggeri på landsplan reduceredes betydeligt, og af familiernes besiddelse af varige forbrugsgoder $\varnothing$ gedes antallet af sommerhuse mindst i forhold til besiddelse af en ejerbolig, bil og elementært og mere avanceret udstyr til helårsbogen. Et tydeligt bevis på, at sommerhusbesiddelse var et yderst marginalt forbrugsgode, der var afhængig af ikke bare den enkeltes husstandsindkomstniveau, men også af konjunkturforløbet.

\section{Sommerbyernes forandring}

På grundlag af hovedspørgsmål B har bogen påvist, at de ændrede samfundsøkonomiske forudsætninger for den sidste efterkrigstids mindre sommerhusbyggeri ikke blot førte til en stagnerende udvikling i hovedstadsmetropolens sommerhusbyer, men tillige at disse blev kendetegnet af en forandret social sammensætning af førstegangsejere af nye sommerhuse, der samtidig opnåede et betydeligt kvalitativt løft i forhold til den første efterkrigstids sommerhusbyggeri.

\section{Stagnation}

Da der i spekulativ forventning om en lang periode med vedvarende tilvækst i sommerhusbyggeriet i hovedstadsmetropolens sommehusbyer i den første efterkrigstid var udstykket langt flere grunde end, der nåede at blive bebygget inden den sidste efterkrigstids tilbageslag i sommerhusbyggeriet indtraf, kunne periodens begrænsede tilvækst i sommerhusbygeriet uden problemer holdes inden for disse bymæssige rammer. I det attraktive sommerhusbybælte ved Kattegatkysten var der tidligt i den første efterkrigstid, og før den delregionale fredningsplan og konkrete fredninger op gennem 60 'erne her inddæmmede sommerhusbysspredningen, udstykket să rigelige arealer, at dette kunne opsuge en betydelig del af den sidste efterkrigstids sommerhusbyggeri.

Mens kystens sommerhusbyer tegnede sig for godt halvdelen af den første efterkrigstids nye sommerhuse, blev de i den sidste efterkrigsperiode således i stand til at opsuge tæet ved 60 procent af dennes sommerhusbyggeri. Da myndighedernes regionale planindgreb overfor sommerhusbysspredningen, belært af de historiske erfaringer fra Kattegatkysten, i den første efterkrigstid havde været mere udtalte i andre dele af hovedstadsmetropolens åbne land, kunne sommerhusbyerne i Hornsherred i forhold til den første efterkrigstid alene opsuge 
samme andel af den sidste periodes sommerhusbyggeri. I de tidligt bebyggede sommerhusbyer i hovedstadsmetropolens øvrige opland og dem ved Roskilde Fjords nord- og $\emptyset$ stside var bebyggelsesopfyldningen i den første efterkrigstid endda blevet så stor, at disse sommerhusbyers andel af den sidste efterkrigstids sommerhusbyggeri blev langt mindre end $i$ den forudgående periode.

\section{Ulighed}

Udvikledes hovedstadsmetropolens sommerhusbyer i den sidste efterkrigstid inden for allerede givne rammer, undergik de med periodens ændrede økonomiske forudsætninger for sommerhusbyggeri - og erhvervelse forandringer for så vidt den sociale fritidsbeboersammensætning.

Mens den sociale sammensætning af disse førstegangsejere i den første efterkrigstid udjævnedes en smule, blev den i den sidste del af efterkrigstidsperioden på ny præget af større ulighed. Efter at andelen af førstegangsejende arbejdere af nye sommerhuse i den første efterkrigstid var steget, på trods af arbejderklassens mindre andel af erhvervsbeskæftige i hovedstadsmetropolen, reduceredes arbejdernes andel af denne ejergruppe i den sidste efterkrigstid parallelt med klassens mindre andel af erhvervsbeskæftigende for at lægge sig på samme lave niveau som i perioden før midten af århundredet.

Selv om andelen af førstegangsejere af nye sommerhuse fra laget af øvrige funktionærer på samme tid øgendes med ti procent, faldt de mindre selvstændiges andel af samme ejergruppe så meget, at andelen af de to mellemindkomstlag i ejergruppen kun forøgedes med fem procentpoint. Samlet reduceredes andelen af førstegangsejere af nye sommerhuse fra de lavere og mellemste indkomstlag af arbejdere, øvrige funktionærer og mindre selvstændige i den sidste efterkrigstids sommerhusbyer i hovedstademetropolen sommerhusbyer med to procent, mens andelen fra de høje indkomstlaget af større selvstændige og højere funktionærer samlet forøgedes med denne procentsats.

En forandring af den sociale sammensætning af den sidste efterkrigstids sommerhusbyer i hovedstadsmetropolen, der fulgte med og understøttedes af sommerhusets karakter af et yderst marginalt forbrugsgode. Med periodens fald i væksten i den samfundsmæssige indkomst og svagere reallønsudvikling for arbejdere og offentligt ansatte funktionærer bevirkede det, at laget af privatansatte funktionærer, og navnlig de højere, som opnåede en stærkere udvikling i reallønnen, i videre omfang i perioden kunne erhverve det gode, som sommerhuset udgjorde.

I en kombination af den større andel af førstegangsejere af nye sommerhuse, som de højere indkomstlag opnåede i den sidste efterkrigstid og den forsatte teknologiudvikling, der kendetegnede bygge- og anlægssektoren, opnåede periodens sommerhusbyggeri et så signifikant løft, at det på alle parametre for sommerhusstandard hævede sig signifikant i forhold den første efterkrigstids sommerhuse.

Det nye sommerhus i hovedstadsmetropolens sommerhusbyer i den sidste efterkrigstid blev således i gennemsnit $20 \mathrm{~m}^{2}$ større, rummede en større andel med fire eller flere værelser, fuldisoleredes i 96 procent af tilfældene og udrustedes i et større omfang med en skorsten; muret eller et aftræksrør af metal. En forsvindende del opførtes på piller og var ikke udrustet med toilet, mens 86 procent havde badefaciliteter. Alle havde indlagt vand og var tilsluttet spildevandsafledning i form af sivebrønd, septiktank eller offentlig kloak.

Forhold der medvirkede til, at den sidste efterkrigstids sommerhuse efterhånden begyndte at nærmere sig enfamiliehusets niveau, og gør den sidestilling mellem sommer- og enfamiliehuset, som fremgår af Dahlkilds førnævnte værk som sommerlandet arkitektur mere betimelig, jf. Indledningens Kapital 1 . Lige bortset fra at tidens nye enfamiliehuse var 
væsentlige større end de samtidige sommerhuse, og var udrustet med mere avancerede hårde hvidevarer, som vaske- og opvaskemaskiner og dybfrysere, hvilket endnu ikke var videre udbredt i den sidste efterkrigstids sommerhuse.

\section{Regionsudfordringen}

Har kulturhistoriske og kultursociologisk inspirerede litteratur, der har behandlet den sidste efterkrigstids sommerhusbyggeri, kun tangeret træk ved periodens sommerhusbyer, gør dette forhold sig tillige gældende for så vidt de regionale udfordringer, som disse skabte i hovedstadsmetropolen og dem, der var fulgt med fra de første efterkrigsårtiers voldsomme sommerhusbysspredning; jf. Indledningens Kapitel 1 . Med afsæt i bogens hovedspørgsmål $\mathrm{C}$ er det imidlertid påvist, at den sidste efterkrigstids sommerhusbydannelser kom til at indgå i det hidtidige sæt af barrierer for interaktionen i hovedstadsmetropolen, og dermed vedblev at udgøre en af de mange regionsudfordringer for metropolens videre udvikling som en byregion. Hertil kom forandringer af de hidtidige sommerhusbyers karakter og omfanget af helårsbeboelser i disse.

\section{Sommerhusbysspredning}

Selv om der i den sidste efterkrigstid alene opførtes yderligere sommerhuse inden for hovedstadsmetropolens eksisterende sommerhusbyer, udgjorde de fortsat i en betydelig regional udfordring. Trods 60 'ernes fredningsplanmæssige dispositioner havde sommerhusbyerne ikke blot beslaglagt meget omfattende højklassede naturområder og tillige landskaberne helt op til samtlige af de strande, der var egnet til badning og friluftsophold, men dermed også reduceret den brede befolknings adgang til og benyttelse af de sparsomme mest rekreativt og natur- og kulturhistorisk værdifulde dele af hovedstadsmetropolens åbne land.

Sommerhusbyernes samspil med det åbne lands stærkt tiltagende bymæssige bebyggelse og dets både rekreative og erhvervsmæssige anvendelse stod herudover tilbage fra den første efterkrigstid som betydelige regionsudfordringer. Regionale udfordringer for kapitalens mest rationelle lokalisering af boligbyggeri og erhvervsvirksomhed og offentlige myndigheders udlæg af trafik-, forsynings- og spildevandsledninger og varmeforsyningsområder. Tilsvarende regionale udfordringer knyttede sig til den spildevandbelastning og det trafikale pres på regionale veje, som sommerhusbyerne bidrog med, disses forsyningsbehov og det $\varnothing$ gede sygehusbehandlingsbehov, som de store befolkningskoncentrationer i sommerhusbyerne bidrog til på samme tid, som hovedstadsmetropolens befolknings- og bebyggelsesmæssige tilvækst netop i den sidste efterkrigstid var størst i dens ydre amtskommuner.

Hertil føjede sig, at den buffer som de tilbageværende ledige ubebyggede parceller i sommerhusbyerne repræsenterede, trods den sidste efterkrigstids mindre sommerhusbyggeri var ved at blive opbrugt, hvorved der var en latent risiko for yderligere sommerhusbysspredning. En risiko, der forstærkedes af, at mange ældre sommerhusbyer med deres meget betydelige omfang og moderne sommerhusbyggeri var begyndt at miste deres karakter af et regionalt rekreativt ferie- og fritidsbomiljø med dertil hørende større individuel frihed, mere rummelighed og rigere kontakt mellem beboerne. En udvikling, der skabte behov for nye udlæg af sommerhusbyer i de resterende ydre og endnu mere afsondrede dele af hovedstadsmetropolens åbne land, hvor netop højklassede naturværdier stadig stod tilbage.

\section{Helårsbeboelse}

En udviklingstendens, der i den sidste efterkrigstid understøttedes af den stadig mere udbredte helårsbeboelse i sommerhusbyer, der fulgte med tiden større gruppe af pensionister og $ø$ konomiske lavvækst. Sommerhusbyers omdannelse til forstad havde ganske vist været kendt $\mathrm{i}$ hovedstadsmetropolens indre dele både i tiden for første verdenskrig, i mellemkrigstiden og den første efterkrigstid, men havde ikke i større omfang gjort sig gældende i sommerhusbyerne i hovedstadsmetropolens ydre dele. 
Med mere udbredte helårsbeboelse i disse sommerhusbyer var der en risiko for, at disse over tid forvandles til bydannelser svarende hovedstadsmetropolens $\varnothing$ vrige satellitbyer, hvilket ville reducerer mængden om regionale byområder til rekreativ fritidsbeboelse og underminere sommerhusbyernes egenart og hidtidige fællesanlæg alene skabt for et rekreativt fritidsliv. En udvikling, der ikke alene ville føre til meget betydelige og kostbare kommunale udgifter til forsynings og spildevandsanlæg og velfærdsydelser og- tilbud, men også ville lægge pres på hovedstadsmetropolens tilbageværende rekreative område og skabe behov for udlæg af yderlige sommerhusbyer med deraf følgende regionsudfordringer.

\section{Regions- og sektorplanlægning}

I forhold til håndteringen af de regionsudfordringer, der i den sidste efterkrigstid knyttede sig til sommerhusbyerne, har den foreliggende litteratur hæftet sig ved enkelte træk ved den sidste efterkrigstids plan- og reguleringsindgreb; jf. Indledningens Kapital 1. Den byplanhistoriske litteratur har săledes omtalt de statslige cirkulærer fra omkring 1980, der gennemførte et midlertidigt stop for videre udlæg af sommerhusbyer, og siden forhindrede yderligere sommerhusbyggeri ved landet kyster. Ved mere lokale studier påviser værket om sommerhusbyer i det vestlige Limfjordområde, at stedlige lokale og regionale myndighedsgreb gradsvist og særlig i 70'erne fik mere styr på sommerhusbysspredningen. Med dette udgangspunkt og afsæt i hovedspørgsmål $D$ har denne bog påvist: Dels forudsætningerne for og arten af den regions- og sektorplanlægning, der i den sidste efterkrigstid inddæmmede de forskellige regionale udfordringer, der udsprang af efterkrigstidsperioden sommerbydannelser i hovedstadsmetropolens åbne land. Dels resultatet af disse regionale plangreb.

\section{Forandrede rammevilkår}

Bogen har i den forbindelse påvist, at oprettelsen af et regionskommunalt organ for hele hovedstadsmetropolen og en til dette knyttet regions- og sektorplanlægning udgjorde forudsætningen for, at alle sider af metropolens udfordringer, herunder dem der udsprang af den sommerbysspredning, blev underkastet gennemgribende regionale plan- og reguleringsmæssige dispositioner.

\section{Hovedstadsrådet}

Mens kommunalreformen i 1970 sammenlagde købstads- og sognekommuner til primærkommuner, reducerede antallet af amtskommunerne og tillagade disse et stærkt udvidet ressort, kom hovedstadsmetropolen ud over kommunesammenlægninger i den ydre del til at stå uden for reformen. Dens tre amtskommuner opretholdes, mens primærkommuners grænser i metropolens indre del blev uforandrede og de to hovedstadskommuner som de eneste i landet fortsatte som både primær- og amtskommuner.

Anvendtes 1970-kommunalreformens præmisser således ikke på primær-og amtskommunalt niveau i hovedstadsmetropolen, overførtes dens princip om "én by, én kommune" på hele metropolen, idet der i 1974 oprettedes et indirekte valgt kommunalt regionsorgan i form af Hovedstadsrådet, der med en stadig større forvaltning skulle tilvejebringe regionale rammebetingelser for hovedstadsmetropolens funktion som en byregion i henseende til fysisk planlægning, tilvejebringelse af regionale rekreative områder, trafikplanlægning, drift af kollektiv trafik gennem det umiddelbart efter oprettede HT, planlægning-, tilsyns- og regulerings opgaver indenfor den regionale forsynings-, sygehus- og miljøsektor. Et omfattende regionsressort, der bevirkede, at amtskommunerne i hovedstadsmetropol fik færre opgaver end i resten af landet, og på en række områder underlagdes Hovedstadsrådets dispositioner.

Formålet med 1970-kommunaleformen og den særlige overregionale kommunestruktur i hovedstadsmetropolen var at overføre hovedparten af velfærdsstatens opgaver til primær- og amtskommuner og betydelige dele af de regionale i hovedstadsmetropolen til Hovedstadsrådet. Staten opgaver blev dermed reduceret til at varetage nationale opgaver, så som DSB, postvæsen, universiteter og andre videregående uddannelsesinstitutioner, politi- og 
retsvæsen, og at styre udviklingen i hele den kommunale sektor via regelstyring, bekendtgørelser og cirkulærer, og økonomistyring gennem bloktilskud og refusioner aftalt med de kommunale parter. Et ny og meget afgørende styringsredskab blev sektorplanlægning, hvori statsmagten ud for sektorvise landsplanskitser- og redegørelser og konkrete bestemmelser fastlagde retningen for de planer, som primærkommunerne og navnlig amtskommunerne og i hovedstadsmetropolen Hovedstadsrådet udarbejdede inden for de opgaveområder, som disse skulle varetage.

\section{Regionsplanlægning}

Centralt i Hovedstadsrådets og de øvrige amtskommunernes sektorplanlægning blev regionsplanlægningen, der både omfattede overordnede planrammer og- og mål for den regionale byvækst og- spredning og for fordeling af bebyggelsesarter og sektorplandele, hvor de fysiske dimensioner af de forskellige sektorplanområder funktionelt skulle indpasses og samstemmes med de overordnede planrammer. Ved regionsplanlægning tog Hovedstadsrådet udgangspunkt i Regionsplan 1973, som var blevet udarbejdet af Egnsplanrådet, og fra statsmagtens side var blevet godtaget som grundlag for rådets videre fysiske planarbejde.

Udarbejdet i de første år af 70'erne afspejledes den første efterkrigstids vækstcenterteoris præmisser i Regionsplan 1973s gigantiske forestillinger om hovedstadsmetropolens befolknings- og byæskt inden for den 30 årige planperioden, som regionsplanen arbejdede med. Ud fra disse forudsætninger opererede Regionsplan 1973 derfor med en så omfattede beskæftigelses- og befolkningsmæssigtilvækst, at hovedstadsmetropolens befolkningstal i 1990 ansattes til 1,9 mio. og til et sted mellem 2 og 2 1/2 mio. indbyggere efter årtusindeskiftet. Selv på den korte bane frem til 1990 skulle der ud fra den anlagte vækstdimension i denne periode tilvejebringes meget betydelige erhvervsarealer og byrum for 250.000 nye boliger.

I denne periode skulle kun en mindre del af bolig- og erhvervsbyggeriet placeres i de hidtidige byzoner, der ikke måtte udvides, i forstadsbåndene, hvor den hidtidige fordeling af bebyggelsesarterne skulle fastholdes. Størsteparten bolig- og erhvervsbyggeri var således tænkt henlagt til byvækstsområder omkring en såkaldt hovedstruktur, der skulle opsuge størstedelen af hovedstadsmetropolens estimerede befolknings- og erhvervsmæssige vækst.

Hovedstrukturen omfattede en gennemgående en km bred transportkorridor med regionale forsyningstransmissionsledninger, motorvej og en højklasset jernbane fra Hillerød i nord til Køge i syd. I de knudepunkter, som opstod, der hvor denne transportkorridor krydsede de radiale forstadsbånd og deres trafiklinjer skulle der dannes erhvervsmæssige A-zoner til industri, centeradministration og institutioner syd for Hillerød, ved Måløv og Høje Tåstrup og sydvest for Køge. Ud over disse A-zoner indgik i Regionsplan 1973

grønne rekreative A-zoner, der skulle danne overgang herfra til de meget omfattede rekreative naturområder, som i det nordligste Nordsjælland, Hornsherred og områderne sydøst herfor indgik i regionsplanen.

Med hovedstadsmetropolens stagnation i den sidste efterkrigstid og et landspolitisk ønske om at styrke en decentral urbanisering ude i landet på bekostning af hovedstadsmetropolen og Aarhus-området, blev Regionsplan 1973 store overordnede planrammer og- og mål i Første Etapeplan 1977-1992 og 80 'ernes regionsplantillæg beskåret så meget, at hele grundlaget bag regionsplanen fortonede sig for til sidst helt at udgå i Hovedstadsrădets sidste regionsplan. Regionsplan 1989 vendte således i udvidet form tilbage til det tankegods, der lå til grund for Fingerplanen fra 1948 og den første etapeplan fra 1963 i form af radiale forstadsbånd, der med deres hidtidige fordeling af bebyggelsesarterne blot forlængedes til og integreredes med købstadsringens store købstæder og pendlersatellitbyerne, der lå uden for denne Fingerby. 


\section{Sektorplanlægning}

Med Hovedstadsrădets virksomhed op gennem den sidste efterkrigstid tilvejebragtes ud over regionsplanlægningen en lang række andre regionale rammebetingelser for hovedstadsmetropolens videre udvikling som en funktionel byregion. Selv om 60'ernes vidtrækkende motorvejsplaner, som følge af periodens kriser og landspolitisk opprioritering af den kollektive trafik, under Hovedstadsrådets regionale trafikplanlægning alene fuldførtes i de indre dele af hovedstadsmetropolen, hvor trafikpresset var mest voldsomt, omfattede denne sektorplanlægning tillige den kollektive trafik.

På dette område opnåede Hovedstadsrådet sine største resultater, idet alle sider af den kollektive trafiks drift blev underlagt rådets HT, der etablerede et samlet og sammenhængende enhedssystem med samme køreplans- og taktsordning for både S- og regionalbaner og alle former for busdrift. I dette system varetog HT selv en betydelig del af busdriften, mens den $\varnothing v$ rige del af denne på entreprenørkontrakt udførtes af private aktører. Helt tilsvarende S- og regionalbanedriften, hvor DSB var udførende entreprenør for HT. Samlet skabte Hovedstadsrådet trafikplanlægning og HTs meget betydelige forbedring af den kollektive trafik stærkt forberede rammebetingelser for varers, tjenesters og arbejdskrafts bevægelighed mellem hovedstadsmetropolens funktionelt forskelligartede byenheder.

For arbejdskraftens produktionsevne og realkapitalens funktionalitet ydedes tillige et afgørende bidrag gennem Hovedstadsrådets sektorplanlægning og konkrete tilsynsmæssige og administrative virksomhed $i$ henseende til regional vand- og energiforsyning af og spildevandslednings- og affaldshåndtering fra boligområder og produktionsanlæg - og områder. For arbejdskraftens produktionsevne medvirkede Hovedstadsrådets sygehusplanlægning til, at sygehustilbuddet i hele hovedstadsmetropolen ikke blot højnedes, men tillige blev regionalt mere ensartet.

Samlet lykkedes det for Hovedstadsrådet med sin sektorplanlægning, tilhørende tilsynsmæssige og regulerende administrative beføjelser og drift af den kollektive trafik at håndtere den samlede buket af regionsudfordringer, der hidtil fragmenteret eller $\mathrm{i}$ utilstrækkeligt omfang var forsøgt løst af forskellige offentlige myndigheder. Dispositioner, som sammen med regionsplanlægningen fik afgørende betydning for interaktionen mellem hovedstadsmetropolens funktionelt forskelligartede byenheder og dermed for dens sammenhængskraft og funktion som én byregion.

\section{Sektorplanlægning af det åbne land}

Blandt Hovedstadsrădets sæt af sektorplanopgaver har bogen påvist, at den regionale planlægning og regulering af arealanvendelse af hovedstadsmetropolens åbne land blev et af de betydeligste, og at håndteringen af metropolens sommerhusbysspredning heri fik en særdeles central placering.

\section{Arealanvendelse $i$ det abne land}

Præmisserne for denne planlægning og regulering var i realiteten fastlagt allerede $\mathrm{i}$ mellemkrigstiden, men bogen har påvist, at disse blev formuleret mere markant og udvidet $\mathrm{i}$ den rekreative politik, som den socialdemokratiske regering fremlagde i starten af 70 'erne. Som hidtil skulle det offentlige både beskytte kultur- og naturhistoriske værdier i det åbne land og med et socialt sigte reservere det for hele befolkningens rekreative friluftsliv, men som noget nyt tillige sikre betydelige arealer, enten ved direkte jorderhvervelse eller plandispositioner, til dens fritidsbosætning i landskabelige omgivelser.

Som for andre af de områder, der indgik i velfærdsstatens betydelige aktionsfelt, blev det overladt til Hovedstadsrådet i hovedstadsmetropolen og amtskommunerne i resten af landet at udmønte den statslige rekreative politik gennem sektorplanlægning og konkrete regionale dispositioner. Af hensyn til at det åbne land i videste muligt omfang kunne benyttes rekreativt af metropolbefolkningen, indgik i Hovedstadsrådets bindende sektorplanlægning på området 
en afgræsning af dets erhvervsmæssige udnyttelse. Rådet udpegede således 14 grusgravningsområder i hele hovedstadsmetropolen og andre grusgrave, hvor aktiviteterne på sigt skulle afvikles, og områderne af naturmæssige og rekreative hensyn skulle tilbageføres til deres oprindelige naturlige tilstand.

Ud over fastlæggelse af tilsvarende områder for lergravning, og udnyttelse af forekomster af sten, kalk og tørv, udpegede Hovedstadsrådet i det åbne land beliggenheden, størrelsen og dyrkningsværdien af områder, der skulle opretholdes som produktionsgrundlag for aktivt landbrug og tillige skulle bevares som så af hensyn til de kulturhistoriske værdier, der netop knyttede sig det opdyrkede landskab. Et kultur- og naturbevarende og rekreativt hensyn, der tillige afspejlede sig i Hovedstadsrådets udpegning af og retningslinjer for eksisterende skove og skovrejsning af almene rekreative hensyn i bynære områder eller i landbrugsområder med jord af lav dyrkningsværdi.

På grundlag af de områder i hovedstadsmetropolens åbne land, der i sektorplanlægningen afgrænsedes til forskellige former for erhvervsmæssig udnyttelse, kunne Hovedstadsrådet i sin sektorplanlægning udpegede såkaldte fredningsinteresseområder af landskabelig, kulturhistorisk og biologisk værdi. Interesseområder, hvor kommunerne via kommune- og lokalplaner, stianlæg, træplantning og andre dispositioner ikke blot skulle sikre områderne til friluftsformål, men også give dem de forskellige former for rekreativ anvendelse, alt efter de funktioner, som områderne tillagdes i sektorplanen for det åbne lands arealanvendelse. I form af: Dels daglige regionale fritidslandskaber i nordforstædernes store skov- og søområder og de grønne kiler mellem forstadsbåndene. Dels bynære friluftsområder med stianlæg og tilgængelige friarealer omkring købstæderne i købstadsringen og de uden for liggende satellitbyer. Dels regionale udflugtsområder, eller såkaldte oplevelsesrige landskaber, med en række regionale udflugtscentre med overnatningsfacilitet, naturskoler og skiltning, der gav anvisning på brugen af de omliggende naturområder.

Regionale udflugtsområder, der omfattede det nordligste Nordsjælland, Mølleådalen med omgivende landskaber, det meste af Hornsherred og områderne derfra i sydøstlig retning mod Stevns. For at skabe sammenhæng mellem de daglige fritidslandskaber $\mathrm{i}$ hovedstadsmetropolens indre del og de regionale udflugtsområder i dens ydre åbne land bestemte sektorplanlægningen, at gennemgående og sammenhængende landskaber skulle bevares og passere gennem Regionsplan 1973's transportkorridor via dennes grønne A-zoner.

Da de socialdemokratiske regeringer ud fra den fastlagte rekreative politik op gennem 70 'erne af flere omgange kom igennem med meget betydelige statsmidler til erhvervelse af områder $\mathrm{i}$ det åbne land til mere arealintensive ferie- og fritidsbosætningsformer for den bredere del af befolkningen, så som feriecentre og-byer, marianer, campingpladser, kolonihaver, hytteudlejning, havneanlæg for lystbåd og anden rekreativ anvendelse, kom Hovedstadsrådets sektorplanlægning på området tillige til at omfatte særlige rekreative anlæg. I form af retningslinjer for lokalisering af kolonihaveområder, 13 områder, der kunne udlægges til nye og store campingpladser, og samt nye havneanlæg for joller og mindre lystbåde fortrinsvis i de indre dele af hovedstadsmetropolen og langs Køge Bugt, Roskilde Fjord og Isefjorden.

På grundlag af Hovedstadsrådets sektorplanlægning for det åbne land og konkrete rekreative dispositioner har bogen dokumenteret, at det gennem betydelige fredninger og snævre byzoneudlæg omkring de stedlige rurale bebyggelser op gennem den sidste efterkrigstid lykkedes at sikre bevaring og almen rekreativ udnyttelse af meget betydelige områder i det nordlige Nordsjælland, hele Hornsherred og de store natur- og skovområder sydøst for halvøen. På samme tid og på grundlag af tidligere trufne dispositioner sikredes tillige de såkaldte kileområder i hovedstadsmetropolens indre del via et samvirke af en række forskellige virkemidler og af hovedstadsmetropolens regionalt agerende aktører: Staten, hovedstadskommunerne og-amtskommunerne, de enkelte stedlige kommuner og siden tillige Hovedstadsrådet. En indsats, der resulterede i, at hovedstadsmetropolen både i dens indre og ydre dele sikredes meget betydelige landskabsmæssige natur- og kulturværdier, 
der på samme tid blev tilgængelig for metropolbefolkningens rekreative friluftsliv og- ophold. En afgørende forudsætning for arbejdskraftens reproduktion og produktionsevne og dermed evne til at indgå i den interaktion, der var afgørende for hovedstadsmetropolens funktionalitet som en byregion.

\section{Sommerhusbyplanlægning}

En signifikant forudsætning for de betydelige resultater, der i den sidste efterkrigstid opnåedes gennem Hovedstadsrådets sektorplanlægning af det åbne lands arealanvendelse, udgjorde den sommerhusbyplanlægning, rådet gennemførte sideløbende hermed. Omkring 1970 havde den første efterkrigstids sommerhusboom ført til, at hovedstadsmetropolens sommerhusbyer havde bredt sig over betydelige kyststrækninger med tilhørende baglande, og med store arealkrav til sommerhuse og haveanlæg og en relativ begrænset benyttelse i weekend- og ferieperiode af en familie var blevet en arealekstensiv fritidsbosætningsform for 10 procent af befolkningen, der lagde beslag på betydelige dele af det åbne land, som til rådighed for rekreativ benyttelse af de resterende 90 procent af samme.

Da denne markante ulighed i mulighederne for et rekreativt friluftsliv ville blive forstærket yderligere af den tiltagende individuelle fritidsbosætningsform, som fortsat sommerhusbysspredning var udtryk for, og som de store borgerlige partiet værnede om, og da det regeringsbærende socialdemokrati op gennem 70 'erne i sin rekreative politik samtidig entydigt tilkendegav, at denne byspredning måtte standses for, at den del af befolkningen, der ikke havde råd til et sommerhus eller hotelophold, kunne få adgang til de stadig mere knappe rekreative ressourcer i det åbne land, blev denne i realiteten klassebaserede ulighed yderlige politiseret. Ud fra velfærdssystemets kultur- og fritidssøjle og den rekreative politik, der i 70' erne med endnu større tyngde blev indlejret heri, valgte velfærdsstaten i dette spændingsfelt på ny at prioritere de almene friluftshensyn højere end de individuelle og dermed i endnu højre grad end tidligere at tilvejebringe kyst- og landskabsområder for brede samfundslags rekreative friluftsliv og fritidsbosætning i samme områder.

I form af sommerhusloven fra 1972 og cirkulærer fra slutningen af 70 'erne og de første år af det efterfølgende årti, der gennemførte et midlertidigt stop for udlæg af yderlige sommerhusbyer, siden forhindrede yderlige sommerhusbyggeri ved landet kysters, fastlagde, at nye sommerhusbyer ikke måtte komme til at danne kæder af sådanne bebyggelser op til de kystnære områder, og henviste disse til område længere inde i baglandet. Centralstatsligt rammerne for en regional sommerhusplanlægning, der desuden skulle medvirke til, at ubebyggede dele af eksisterende sommerhusbyer omdannedes til mindre arealkrævende fritidsbosætningsformål så som campingpladser, feriebyer, feriecentre m.m. Fritidsbosætningsformer, der ad den vej eller gennem offentlig jorderhvervelser kunne udgøre et alternativ til sommerhusene og stilles til rådighed for de samfundslag, der økonomisk ikke magtede erhvervelse og besiddelse af en sådan fritidsbolig.

Med disse bestemmelser og retningslinjer, har bogen påvist, at der blev lagt centrale pejlemærker for Hovedstadsrådets, og i resten af landet amtskommunernes, sektorplanmæssige håndtering af sommerhusbysspredningen ud fra de præmisser, der var lagt for den velfærdstatslige rekreative politik. Herved kom den regionale sommerhusbyplanlægning til at udgøre et integreret hele i Hovedstadsrådets samlede sektorplanlægning for det åbne lands erhvervsmæssige, natur- og kulturbeskyttende og rekreative arealanvendelse. Herunder rådets udlæg af alternative og mere arealintensive fritidsbosætningsformer, der kunne anvendes af et relativt større befolkningsvolumen end de areal- og benyttelsesmæssigt ekstensive sommerhusbyer.

Som følge af de særlige regionsudfordringer, der knyttede sig til hovedstadsmetropolens sommerhusbysspredning og det åbne lands knappe arealressourcer til både erhvervsmæssig og rekreativ udnyttelse, har bogen endvidere dokumenteret, at Hovedstadsrådet op gennem 70 'erne og i det efterfølgende årti gennemførte en langt mere restriv sommerhusplanlægning, eller rettere fritidsbosætningsplanlægning, end amtskommunerne i resten af landet. Allerede ved Hovedstadsrådets og senere Miljøministeriets godkendelse af Regionsplan 1973 indgik her et bindende forbud mod forsat sommerhusbysspredning omfattende såvel udbygning af eksisterende og udlæg af nye sommerhusbyer. Forbuddet opretholdes i hele Hovedstadsrådets funktionsperiode i dettes 
sektorplanlægning for fritidsbosætning, som tillige kom til rumme restriktioner for eksisterende sommerhusbyers overgang til byzone og helårsbeboelse og andet byggeri i det åbne land.

Hovedstadsrådet fritidsbosætningsplanlægning udstak således tre km brede kystnære zoner, hvor der ikke måtte etableres nye anlæg, opføres nogen form for nybebyggelse eller gennemføres udvidelse af eksisterende anlæg og bebyggelse til ferie- og fritidsformål med udtagelse af mindre feriecentre, mindre udvidelser af eksisterende feriecentre samt udlæg af campingpladser. For at fremme tilsvarende fritidsbosætningsformer lagde Hovedstadsrådet begrænsninger for yderlige udstykning og bebyggelse i ubebyggede dele at eksisterende sommerhusbyer, og udpegede blandt disse først ni og siden seks nærmere fastlagte områder, der kunne overgå til arealekstensiv fritidsbosættelse så som campingpladser, feriebyer, vandrehjem, hytteudlejning m.m. Områder, der således kunne supplere de udlæg af kolonihaveområder, campingpladser og lysbådshavneanlæg, der indgik i Hovedstadsrådets samlede sektorplan for det åbne lands arealanvendelse.

\section{Planresultatet}

I den yderst begrænsede danske litteratur om den sidste efterkrigstids regionale planindgreb overfor sommerhusbysspredningen har værket om sommerhusbyerne i det vestlige Limfjordområde anført, at sådanne indgreb førte til, at sommerhuslandskabet i en lang periode frem til årtusindeskiftet ikke udvikledes væsentligt hverken på landsplan eller ved Limfjorden; jf. Indledningens Kapitel 1. Tilsvarende har landskabsarkitekten Jørgen Primdahl konstateret, at der i perioden kom mere styr på byvækst og sommerhusudvikling, idet regionsplanerne efterhånden kom til at omfatte og beskytte det åbne land. Konklusioner, som denne bog bekræfter, men for hovedstadsmetropolens vedkommende yderligere har underbygget.

Med Hovedstadsrådets fritidsbosætningsplanlægning lykkedes det således i den sidste efterkrigstid i hovedstadsmetropolen at sætte en afgørende bom for sommerhusbyernes videre udbredelse i metropolens åbne land, hvor rådets sektorplanlægning for dettes anvendelse ud fra almene samfundsmæssige bevarings- og friluftsinteresser sikrede ikke blot nødvendige erhvervsinteresser, men også omfattende rekreative områder med alternative fritidsbosætningsformer til sommerhuset.

Efter årtiers fragmenteret og utilstrækkelig planlægning opnåede Hovedstadsrådet på blot 15 år dermed at gennemføre en gennemgribende regional sektorplanlægning, der inddæmmede de betydelige regionale udfordringer, der hidtil knyttede sig til det åbne lands anvendelse. Dispositioner, der samlet havde betydning for kapitalens samfundsmæssigt mere rationelle lokalisering af forskellige former for erhvervsvirksomhed, arbejdskraftens reproduktion og produktionsevne og dermed for de to produktionsfaktorers interaktion i den byregion, som hovedstadsmetropolen udgjorde. Afgørende faktorer for både hovedstadsmetropolens funktionalitet som en byregion og for velfærdsstatens kultur- og tidssøjle.

En tilsvarende planudvikling, som den internationale forskning påviser i særlig grad, men tidligere, kom til at gennemsyre planlægningen i Sverige i efterkrigstiden og navnlig i 60 'erne; jf. Indledningens Kapitel 1 . Her blev det, som i Danmark som helhed og i dettes hovedstadsmetropol i særdeleshed, målet at friholde mest muligt af det åbne landskab for sommerhusområder og på samme at integrere dem i dette sammen med alternative fritidsbosætningsformer. Virkemidlerne i den retning blev i de stockholmske byregion, som i det danske hovedstadsmetropol, et total forbud mod videre sommerhusbyggeri.

Udenfor for de større byer søgte strikte planbestemmelser samtidig at friholde betydelige kystområde ved have, søer og elve og bjergområder for sommerhusområder, samtidig med at disse $\mathrm{i}$ andre svenske naturområder blev integreret i særligt udlagte delområder for fritidsbosætning med større fælles rekreative arealer og servicefaciliteter for dagligvareindkøb, idrætsanlæg m.m. Hertil kom, at den svenske planlægning, i lighed med den danske, søgte at tilvejebringe arealmæssige rammer for de campingpladser, den hytteudlejning og de andre friluftsressorts, som kunne afbøde behovet for udlæg af nye sommerhusområder. Samlet 
dispositioner fra såvel statslig som regionkommunal side, som, svarende til danske, søgte at sikre den almene rekreative adgang til og bevaring af det svenske landskab og samtidig med planmæssigt at indpasse nødvendigt nyt sommerhusbyggeri i dette.

\section{Sommerhusbyerne og de øvrige regionsudfordringer}

I lighed med velfærdsstatens foranstaltninger til imødegåelse af sommerhusbysspredningen, har dens øvrige greb for at håndtere de regionale udfordringer, der knyttede sig til efterkrigstidens sommerhusbydannelser ikke været berørt i den foreliggende litteratur. På den bagrund har denne bog tillige dokumenteret, hvorledes også disse udfordringer blev inkluderet i den øvrige sektorplanlægning, som Hovedstadsrådet gennemførte i den sidst efterkrigstid.

\section{Regionaltrafikken}

Selv om Holbæk- og Helsingørmotorvejene færdiggjordes i fuld udstrækning i den første del af 70 'erne og dermed sikrede en højklasset forbindelse frem mod sommerhusbyerne i den sydlige del af Hornsherred og den østlige del af sommehusbybæltet ved Kattegat, skabte den sidste efterkrigstid beskæringer af 60 'erne store motorvejsplaner betydelige vejtrafikale udfordringer i forstadsbåndet langs den ydre del af Frederikssundsbanen og i det nordligste Nordsjælland. Netop, der hvor den sidste efterkrigstid by- og befolkningstilvækst i hovedstadsmetropolen fandt sted og samtidig der, hvor trafikpresset forstærkedes i ferieperioderne og weekends som følge af de store sommerhusbyer i den nordlige del af Hornsherred, ved Roskilde Fjords nord- og østkyst og de øvrige dele af Kattegatkysten.

Udfordringer, som de ydre hovedstadsmetropolens ydre amtskommuner og staten i den sidste efterkrigstid fors $\varnothing$ gte at inddæmme ud fra Hovedstadsrådets trafikplanlægning. I stedet for helt at opgive Hillerødmotorvejens videre nordlige forløb, blev den i stedet udlagt som trafikmotorvej fra Allerød til lige syd for Helsinge og Græsted, hvorved der skabtes forbedrede vejforbindelser til de fleste pendlersatellitbyer i det nordligste Nordsjælland og hovedparten af den øvrige del af sommerhusbybæltet ved Kattegatkysten. Af betydning for vejtrafikken hertil og til pendlersatellitbyer og sommerhusbyerne i den øvrige del af hovedstadsmetropolens ydre åbne opland blev tillige amtskommunernes udvidelse af både radiale og tværgående landeveje. Selv om disse vejanlæg samlet ikke stod mål med den stadig større biltrafik i hovedstadsmetrolen ydre del, opnåedes der i den sidste efterkrigstid en signifikant forbedring af de regionale vejforbindelser til og fra metropolens sommerhusbyer og tillige til dens øvrige rekreative områder.

Skønt om Hovedstadsrådets kollektive trafikplanlægning og- drift fik tyngdepunkt i den indre del af hovedstadsmetropolen, søgte HT i metropolens ydre åbne opland, hvor både satellit- og sommerbyerne var lokaliseret til, her at udvide både sidebane- og busdriften og at opnå en fuld integration af samtlige buslinjer, disses forbindelse med hinanden og med S-, regional- og sidebanerne, således at hele hovedstadsmetropolen opnåede en samlet langt større kollektiv trafikal sammenhængskraft. Således nyudlagdes lange radiale regionsbuslinjer fra de mere centrale dele af hovedstadsmetropolen, samtidig med at flere lag af regionale tværgående busforbindelser mellem destinationer i metropolen yderområder forstærkedes med en lagt hyppigere og sammenhængende drift eller helt nye ruter.

Fra de ydre S-banestationer og fra købstadsstationerne, hvorfra der var hurtig S- og regiontogsforbindelse til hovedstadsmetropolens indre dele og selve hovedstaden, udlagde HT desuden et større net af buslinjer til de mere rurale oplande, der sammen med opgraderingen af driften af sidebanerne i samme oplande skabte en stærkt forbedret kollektiv trafik i disse dele af metropolen med hurtigere og hyppigere forbindelser herfra til hovedstadsmetropolens mere centrale dele. Ude i de rurale oplande udlagdes tillige et mere forgrenet lokalt busnet mellem de små bysamfund, herunder sommerhusbyerne, og ud til de regionale udflugtsmål, som indgik i regionsplans oplevelsesrige landskaber. Samlet satte den sidste efterkrigstids signifikante opgradering af hovedstadsmetropolens kollektive trafikbetjening sig også igennem 
i dens ydre del, hvorved der også for dem der var henvist til den kollektive trafik, opnåedes en langt bedre tilgængelighed til metropolens sommerhusbyer og rekreative områder.

\section{Regionalforsyning}

På trods af sommerhusbyernes beliggenhed i hovedstadsmetropolens ydre åbne opland blev de også $i$ et vist, men mindre, omfang berørt af Hovedstadsrådets sektorplanlægning på det regionale forsyningsområde. Ned gennem Hornsherred og mellem halvøens østlige og vestlige sommerhusbyer opsattes således en 400 kv højspændingsmasteføring fra Kyndbyværket med videre forbindelse til Asnæsværket ved Kalundborg Fjord. Til gengæld udgik af Hovedstadsrådets elforsyningsplanlægning et atomkraftværk ved Sømmer på Hornsherreds vestside, der med de særlig indskrænkning i arealanvendelsen i en radius af $10 \mathrm{~km}$ fra værket ville have haft katastrofale konsekvenser for en betydelig del af halvøens sommerhusbyer. For sommerhusbyerne elektricitetsforsyning fik disse regionale dispositioner ikke betydning, da denne lokalforsyning blev varetaget af NESA, og stod uden for Hovedstadsrådets sektorplanlægning i henseende til føring af regionale forsyningslinjer.

Inden for det forsyningsmæssige sektorplanområde opnåede Hovedstadsrådet de mest vidtrækkende resultater for så vidt varmeforsyningsplanlægning. Denne rykkede dog først sent ud til de yderste dele af hovedstadsmetropolen, og her blev alene sommerhusbydelenene af Gilleleje og sommerhusbyen Ejby Strand i Hornsherred omfattet af henholdsvis fiskerlejets og den tæet ved liggende landsbys lokale fjernvarmenet. Mens andre sommerhusbyer $i$ et vist omfang tilsluttes det regionale naturgasforsyningsnet, kom størsteparten af hovedstadsmetropolens sommerhusbyer til at indgå i de af Hovedstadsrådet udpegede områder for individuel opvarmning, hvortil der knyttedes bestemmelser om eventuelle mere miljørigtige omlægninger $\mathrm{i}$ form af anvendelse af alternative energikilder som træbrænde, flis, briketter, halm og biogas.

Selv om de dele af hovedstadsmetropolens åbne land, hvor sommerhusbyerne var lokaliseret til, lå uden for Københavns Kommunes og Sjælsø-værkets vandmonopol, og kommunerne dermed var selvforsynende med vand, fik Hovedstadsrådets regionale vandindvindingsplanlægning her en vis indflydelse. Kommunerens stedlige vandingsvindingsvolumen og vandpriser ansattes således i denne sektorplanlægning, der tillige udpegede områder, hvor der ikke måtte gives nye vandindvindingstilladelser, og eksisterende vandindvindingstilladelser ikke kunne udvides. Disse udgjorde såkaldte kerneområder og spredningskorridorer for plante- og dyreliv og særlige naturområder, hvor der af hensyn til vandgennemstrømingen i vådområder og dermed af hensyn til plante- og dyrelivet ikke måtte foretage yderligere vandindvinding.

I de områder hvor sommerhusebyerne var lokaliseret, gjaldt disse bestemmelser i det nordligste dele af Hornsherred, et midt liggende strøg på halvøen og i dens sydligste del samt områder $i$ kystbaglandet ved dele af både Kattegatkysten og østsiden af Roskilde Fjord. Kommuner, der her ikke kunne indvinde tilstrækkelig vand på eget område, indgik efter Hovedstadsrådets anvisninger og medvirken leveringsaftaler med nabokommunerne. Med sin vandindvindingsplanlægning sikrede Hovedstadsrådet dermed, at den del af sommerhusbyernes vandforsyning, der kom fra kommunale vandværker, var tilstrækkelig uden, at den belastede de knappe grundvandsforekomster og det naturmiljø, der stod centralt rådets sektorplanlægning af det åbne land anvendelse.

\section{De regionale miljøudfordringer}

Mens betydelige del af hovedstadsmetropolens indre dele opnåede fælleskommunale spildevandsordninger med afskærende og dermed samlede kloaksystemer på tværs af kommunegrænserne og få samlede udledninger til kemisk-biologiske rensningsanlæg, opnåedes sådanne ordninger kun i en række tilfælde i metropolens ydre åbne land. I slutningen af 70 'erne sluttede Køge og Skovbo kommuner sig sammen om en fælles udledning via I/S Køge-egnens Rensningsanlæg i Køge, ligesom der gennemførtes en samlet udledning fra hele Vallø Kommune. Herudover etablerede Helsingør Kommune med udløb i $\varnothing$ resund og Kattegat tre afledningssystemer med biologisk rensning af spildevandet fra Helsingør by, Espergærde, Hornbæk og Hellebæk. Tilsvarende tilvejebragte Frederiksværk Kommune samtidig en samlet kemisk-biologisk renset udledning i Kattegat. 
Spildevandudledning fra kommuner med sommerhusbyer på Nordstevns, på den østlige og vestlige del af Kattegatkysten og ved den nordlige del af Roskilde Fjord østside fik på den måde efter samtidens målestok fuldt tilfredsstillende spildevandsafledning.

I de øvrige dele af den ydre del af hovedstadsmetropolen forsøgte Hovedstadsrådet ad en række omgange forgæves at få etableret fælleskommunale afledningsordninger. Dog formåede rådsforvaltningen ved godkendelse af lokalkommunale spildevandsplaner at tilvejebringe mere ordnede forhold via forbud mod udledning af urenset spildevand og krav om nedlæggelse af mekaniske rensningsanlæg, etablering af decentral biologisk-kemisk rensning af spildevandet og en samling af de mange afløb til et mindre antal udledningssteder opnået gennem lokale afskærende kloaksystemer. Foranstaltninger, der førte til, at vandkvaliteten i sø-, å- og kystområde også i og omkring hovedstadsmetropolens sommerhusbyer blev højnet i betydelig grad i forhold til de uacceptable tilstande, der her mange steder gjorde sig gældende i starten af perioden.

For så vidt den regionale affaldshåndtering blev hovedstadsmetropolens sommerhusbyer tillige omfattet af Hovedstadsrådets øvrige miljøsektorplanlægning -og tilsyn. Med mindre forbrændingsanlæg i Gilleleje og Frederikssund var det fælleskommunale affaldshåndteringsselskab I/S AFAV blevet oprettet i midten af 70'erne og betjente med lossepladser i Frederiksværk og Græsted-Gilleleje kommuner i de nordligste og vestlige dele af Nordsjælland. Med tillæg af Skibby Kommune til I/S AFAV's betjeningsområde og Bramsnæs Kommune til I/S KARA's, der med udgangspunkt i forbrændingsanlægget i Roskilde opperede i den ydre sydlige del af hovedstadsmetropolen, blev samtlige af hovedstadsmetropolens sommerhusbyer i den sidste efterkrigstid også omfattet af den regionale affaldshåndteringsordning, som Hovedstadsrådet lagde de regionale rammer for i hele metropolen.

\section{Det regionale sygehustilbud}

Som følge af beliggenheden i den ydre del af hovedstadsmetropolen havde dens sommerhusbyer været henvist til de to ydre amtskommuners mere provinsorganiserede sygehuse. En organisationsform, der allerede i den første efterkrigstid blev udfordret af, at hovedstadsmetropolens forstadsbælter rykkede længere ud metropolens opland, byvæksten i købstæderne i købstadsringen og dannelsen af flere og stadig større pendlersatellitbyer, men også af det store befolkningsvolumen i sommerhusbyerne i ferieperioder og weekend.

For at imødegå disse udfordringer opførte Frederiksborg Amtskommune allerede i 1976 et nyt sygehus i Helsingør, mens det lille og gamle amts- og bysygehus i Frederikssund i 1985 erstattedes med et nyt og langt større sygehus. Sammen med en nyopført stor sengebygning på centralsygehuset i Hillerød kunne Frederiksborg Amtskommunes således opdele sit område i de tre optageområder og opnå en $\mathrm{i}$ vid udstrækning selvforsyning for så vidt sygehusmæssige lokalfunktioner og en betydelig samlet forøgelse af mængden af sengepladser. En tilsvarende oprustning af sygehusvæsnet kom tillige til at omfatte Roskilde Amtskommune i form af en ny senge- og behandlingsfløj på sygehuset i Roskilde og et helt nyt sygehus i Køge. Herved opnåedes en højere grad af selvforsyning med lokale sygehusfunktioner, en opdeling af amtskommunens område i lokale optageområder og en meget betydelig forøgelse af antallet af sengepladser.

\section{Planresultatet}

Med den betydelige folkemængde, der i weekends og ferieperioder tog ophold i hovedstadsmetropolens stadig mere udbredte sommerhusbyer har denne bog påvist, at disse bydannelser op gennem den første efterkrigstid kom til at bidrage til de tiltagende regionsudforinger på det regionale trafik-, forsynings-, miljø- og sygehusområde. Samtidig kom disse regionsudforinger til at generere utilsigtede gener for det rekreative fritid- og ferieophold sommerhusbyerne. I form af langsommelig og besværlig trafikal adgang til disse, primitive forsyningsforhold, betydelig forurening af åløb, søer og fjorde samt et $\mathrm{i}$ forhold til folkemængden utidssvarende sygehustilbud. 
På trods sommerhusbyernes beliggenhed i hovedstadsmetropolens yderste åbne opland, har bogen dokumenteret, at de regionsudfordringer disse bidrog med, og de sideeffekter disse havde for fritidslivet i sommerhusbyerne, i den sidste efterkrigstid blev integrereret i Hovedstadsrådets sektorplanlægning og den tilsynsvirksomhed rådsforvaltningen havde i den forbindelse. Regionale dispositioner, som bogen ser afgørende for, at det i den sidste efterkrigstid i vid udstrækning lykkedes at inddæmme også de regionsudfordringer, der tillige udsprang af efterkrigstidens sommerhusbydannelse til særlig gavn for arbejdskraftens reproduktion, produktionsevne og interaktion i hovedstadsmetropolen og dermed for dennes funktionalitet som en byregion. 


\section{Noter:}

Forkortelser:

FT: Folketingstidende

TA: Tillæg A

TB: Tillæg B

TC: Tillæg C

FF: Folketingets forhandlinger

LF: Landstingets forhandlinger

Lovt.: Lovtidende

${ }^{1}$ Disse sommerhusbydannelser har ikke været genstand for forskningsbaserede undersøgelse, men et lille lokalstudier af sommerhusområder på Bogø, mellem Sjælland og Falster, viser at 92 procent af øens førstegangssommerhusejere i efterkrigstiden havde bopæl i hovedstadsmetropolen. Jf. Henning Bro: Bogøs sommerhusområder i Bogøs historie, 2020. Ovenstående afsnit bygger i øvrigt på de delregionale analyser, der gennemføres i Kapitel 4-7 på basis af det i APPENDIX VII angivne kildemateriale.

2 Hans Christian Johansen: Dansk økonomisk statistik 1914-1980, Danmarks historie, bd. 9, 1985, s. 89 og 91 og

Statistisk tiårsoversigt, 1990, s. 105.

3 Bro: Hovedstadsmetropolen - den danske byregion, 2020, s. 857-858.

${ }^{4}$ Statistisk tiårsoversigt, 1990 , s. $52-53$ og 57.

5 Statistisk tiårsoversigt, 1990 , s. 54.

${ }^{6}$ Velfærdsstatens i tidehverv, Dansk velfærdshistorie, bd. 5, 1973-1993, 2013, (red. Jørn Henrik Petersen, Klaus Petersen og Niels Finn Christiansen), s. 139-214, 245-344-358, 363-466, 525-590, 611-635, 639-759, 831-880.

7 Statistisk tiårsoversigt, 1990, s. 54. Statistisk Årbog, 1988, s. 171.

${ }^{8}$ Afsnittet bygger på kildematerialet angivet i APPANEDIX VI.

${ }^{9}$ Afsnittet bygger på kildematerialet angivet i APPANEDIX VI samt Johansen: Dansk økonomisk statistik 1914-1980, 1985 , s. 88-92 og 97-100.

${ }^{10}$ Statistisk tiårsoversigt, 1990 , s. 50.

${ }^{11}$ Afsnittet bygger på kildematerialet angivet i APPANEDIX VI.

${ }^{12}$ Afsnittet bygger på et kildemateriale, der er fremgår af APPENXIV VI samt:

https://www.berlingske.dk/bolig/typehuse-fra-a-til-z

${ }_{13}$ Betænkning om helårsbeboelse i sommerhusområder. Afgivet af det af Miljøministeriet den 12. september 1980 nedsatte udvalg vedrørende sommerhusloven $\S \S 7$ og 7a, 1981, s. 9, 12-14, 90-91.

${ }^{14}$ Gunther Tress: Development of Second-Home Tourism in Denmark, Scandinavian journal of hospitality and tourism, 2:2, 2002, s. $116-119$.

${ }^{15}$ Afsnittet bygger på kildematerialet angivet i APPANEDIX VI.A.

${ }^{16}$ Afsnittet bygger på kildematerialet angivet i APPANEDIX VI.B.

${ }_{17}$ Afsnittet bygger på kildematerialet angivet i APPANEDIX VI.C.

${ }^{18}$ Afsnittet bygger på kildematerialet angivet i APPANEDIX VI.D.

${ }^{19}$ Kildemateriale som angivet i Appendix VI.

${ }^{20}$ Betænkning om helårsbeboelse i sommerhusområder. Afgivet af det af Miljøministeriet den 12. september 1980 nedsatte udvalg vedrørende sommerhusloven $\S \S 7$ og 7a, 1981, s., 1980, s. 9-81

Bygningsreglementer 1977-1985: http://w2l.dk/file/502102/br syvoghalvfjerds.pdf http://w2l.dk/file/502103/br toogfirs.pdf http://w2l.dk/file/502104/br femogfirs.pdf

${ }^{21}$ Bro: Hovedstadsmetropolen - den danske byregion, 2020, s. 629.

${ }^{22}$ Lovt, 1969, s. 664-667. FT 1968/69, TA, s. 1569-1599. FF, s. 1568-1574, 2114-2158, 7386-7424, TB, s. $2057-2127$.

${ }^{23}$ Bro: Hovedstadsmetropolen - den danske byregion, 2020, s. 926-928.

${ }^{24}$ Samtidig med nedsættelsen af Bent Christensen-udvalget havde hovedstadsmetropolens fem amtskommunale aktører oprettet Egnsplanrådet som et selvstændigt kommunalt regionalt planorgan og dermed taget forskud på en del af den kommende regionsplanadministrative struktur og arbejdets videre forløb inden $r$ denne ramme. I dets korte virkeperiode blev Egnsplanrådet ikke blot inddraget i den eksisterende statslige regionale byplanadministrative koordinationsstruktur, men gennemførte samtidig et omfattende regionsplanmæssigt forarbejde, der med Regionsplan 1973 mundede ud i et regionsplanforslag, som Hovedstadsrådet kunne overtage.

${ }^{25}$ Regionsplan 1973 for hovedstadsregionen. Hovedstruktur og byvækst, 1974, s. 8-15 og 18-43.

${ }^{26}$ Regionsplanen 1. Etape, 1977-1992, 1978, s. 22-33. ${ }^{26}$ Regionsplantillæg 1982, Hovedstadsrådet, 1983, s. Opslag 1-9. J.nr. 82-11331-I/IV, Sekretariatet [Frederiksberg Stadsarkiv, A 10]. Regionsplantillæg 1985, 1987, Opslag 1-9, Emneordnede sager: Hovedstadsrådet IV 1987, [Frederiksberg Stadsarkiv, A 10].

27 Regionsplan 1989, 1989, Opslag 1.1.-1.12.

${ }^{28}$ Planlægning i centraladministrationen, Betænkning fra Udvalget vedr. centraladministrationens

planlægningsvirksomhed, 1975, s. 11-21, 14-15, 28-29, 42, 46-56, 58-71. Hovedstadsrådet. Struktur og opgaver. Rapport fra Indenrigsministeriets udvalg vedrørende lovgivningen om Hovedstadsrådet, 1979, s. 87-91.

${ }^{29}$ Bro: Hovedstadsmetropolen - den danske byregion, 2020, s. 915-926.

${ }^{30}$ Betænkning om naturfredning I. Afgivet af den af Ministeriet for kulturelle anliggende under 23. november 1961 nedsatte Naturfredningskommission, bd. I, nr. 461, 1967 og bd. II, nr. 567, 1967.

${ }^{31} \mathrm{FT} 1968 / 69$, TA, s. $1843-1882, \mathrm{FF}, 2034-2070,8105$. Lovt 1969, s. 650-663.

${ }^{32} \mathrm{FT}$ 1968/69, TA, s. 1843-1882, FF, 2034-2070, 8105. Lovt 1969, s. 650-663. 
33 Dette og ovenstående citater, FT 1971/72, TA, s. 1957-1958.

${ }^{34}$ FT 1971/72, TA, s.1971-1984, FF, s. 2746-2749, 3204-3256, 6168-6205 Lovt, 1972, s., 435-436.

${ }^{35}$ Så Egnsplanrådet den forventede sommerhusbysspredning som en interregional udfordring som aktuel alene kunne håndteres interregionalt, gjaldt det også Egnsplanrådet prognoser for hovedstadsmetropolens byvækst og behov for rekreative områder i et planlægningsperspektiv over 30 til 50 år.

${ }^{36}$ Regionsplanlægningen 1970-1985. Forudsætningerne, 1971, s. 68.

37 Regionsplan 1973, 1974, s. 8-9 og 16-17. Regionsplanlægningen 1970-1985, 1971, s. 43 og-67-69. Regionsplanlægningen 1970-1985. Regionsplanforslag, 1971, s. 19 og 26-27. Strukturplan 1972 for hovedstadsregionen, 1973, s. 48-51 og 62-63. Svend Illeris: Centraladministration og planlægning 1938-ca 1975, 2013, s. og 58-60. Holden Andersen: Lidt om fredningsplanlægningen og om nogle af de mennesker, jeg mødte hen ad vejen, Byplanhistoriske Noter, nr. 29, 1994, s. 13-42. Forslag til udpegning af fredningsinteresseområder, PD 354, Hovedstadsrådet, 1983.

${ }^{38}$ Regionsplanens 1. Etape 1977-1992, 1978, s. 39-89, 98-101, 110-112, 116-117, 122-123, 128-129 og $134-137$.

${ }^{39}$ Lovt. 1978, s, 607, FT 1977/78, TA, s. 2551-2590,FF, 4062-4068, 4935-4960.

40 Henvisninger til lokalplaner i APPNEDIX VII: Kattegatkysten, noter til Del III, Kapitel 10, Afsnit:

Fredningsplanudvalgets planarbejde samt https://www2.blst.dk/nfr/07993.00.pdf

https://www2.blst.dk/nfr/01507.01.pdf https://www2.blst.dk/nfr/05890.01.pdf

https://www2.blst.dk/nfr/07897.00.pdf

https://www2.blst.dk/nfr/07895.00.pdf

41 Statistisk Årbog, 1990 , s. 8 og 2001 , s. 15

42 Bro: Metropoludfordringer, 2019, s. 620-630.

43 J.nr. 121 XI, 1980, J.nr. 121 X, 1980, J.nr. 121 IV, 1981, [Særlig række], J.nr. 121 XV, 1979, J.nr. 121 XIV, 1979 , J.nr. XIII, 1980, J.nr. XI, 1980, J.nr. VI, 1981, J.nr. 82-11331-I/XV, 1983, J.nr. 82-11331-I/VII, 1983, J.nr. 8411331 II, 1984, J.nr. 82-11331 I/XVIII, 1984-1990, J.nr. 82-11331 I/X, 1985, J.nr. 82-11331 I/XIV, 1986 samt Emneordnede sager: Hovedstadsrådet I, 1986, XII 1989. Regionsplantillæg 1982, Hovedstadsrådet, 1983, s. Opslag 36 J.nr. 82-11331-I/IV. Regionsplantillæg 1985, 1987, Opslag 33-35 Emneordnede sager: Hovedstadsrådet IV 1987. Regionsplan 1989, Hovedstadsrådet, opslag 3.1-3.3 samt Emneordnede sager: Hovedstadsrådet XII, 1989 Sekretariatet [Frederiksberg Stadsarkiv, A 10].

${ }^{44}$ Plan for regionale erhvervsarealer til særligt forurenende virksomheder, Hovedstadsrådet, 1982, s. 1-4, J.nr. 121 , I. Regionsplantillæg 1982, Hovedstadsrådet, 1983, s. Opslag 23-24, 27 og 29-31, J.nr. 82-11331-I/IV. Regionsplantillæg 1985, 1987, Opslag 24-25, 28 og 30-32, Emneordnede sager: Hovedstadsrådet IV 1987. Regionsplan 1989, Hovedstadsrådet, opslag 3.7-3.10, 5.5 og 5.7Emneordnede sager: Hovedstadsrådet XII, 1989 Sekretariatet [Frederiksberg Stadsarkiv, A 10].

${ }^{45}$ Citat: FT 1971/72, TA, s. 1957-1958.

46 Lovt. 1972 , s. $518-520$, FT 1971-72, TA, s. $1953-1970$.

47 Citeret efter: Arne Gaardmand: Plan over land, 2016, s. 256.

48 Ministialtidende 1978, s. 502-504. https://dokument.plandata.dk/20 158 APPROVED 1182153462908.pdf https://dokument.plandata.dk/20 209 1550152381887.pdf

https://www.weblager.dk/rest/buildingproject/download/full/11810833\#pagemode=thumbs\&view=Fit

https://dokument.plandata.dk/20 1320045 APPROVED 1294055712821.pdf.

${ }^{49}$ Regionsplanens 1. Etape 1977-1992, Hovedstadsrådet, 1978, s. 39-89, 98-101, 110-112, 116-117, 122-123, 128-

129 og 134-137. Regionsplan 1989, Hovedstadsrådet, 1989, s. 118-119.

50 Minestialtidende 1981 , s. 714-717.

51 Regionsplanens 1. Etape 1977-1992, 1978, s. 39-89, 98-101, 110-112, 116-117, 122-123, 128-129 og $134-137$.

52 J.nr. 121 I og V-VI og J.nr. 82-11331, III, Sekretariatet [Frederiksberg Stadsarkiv]

${ }^{53}$ Regionsplantillæg 1982, Hovedstadsrådet, 1983, s. Opslag 38, J.nr. 82-11331-I/IV, Sekretariatet [Frederiksberg Stadsarkiv, A 10]. Regionsplan 1989, Hovedstadsrådet, 1989, s. 118-119.

54 Regionsplantillæg 1985, opslag 39.1987, Regionsplanredegørelse 1989/4. Energiforsyning. Miljøbeskyttelse, 1989. s., 78-81. Emneordnede sager: Hovedstadsrådet IV 1987 [Frederiksberg Stadsarkiv, A 10].

55 Lovt. 1983, s. 511-512. FF 1982/83, TA, s. 3105-3126. Betænkning om helårsbeboelse i sommerhusområder. Afgivet af det af Miljøministeriet den 12. september 1980 nedsatte udvalg vedrørende sommerhusloven $\S \S 7$ og $7 a$, 1981 , s., 1980 , s. 9-81.

56 Bro: Hovedstadsmetropolen - den danske byregion, 2020, s, 981-986, 1012-1014, 1032-1034 og 1056-1057.

57 Tom Rallis og Uno Helk: Motorvejens historie, Noter 1992-2, Institut for Veje, Trafik og Byplan. Danmarks tekniske Højskole, 1992, s. 19-22. FT 1975/76, s. 698-719 og 994-1021. Lovt. 1976, s. 832-832. FT 1975/76, TA, s. 33813384, FF, s. 5115-5116. Læg: Vejdirektoratets teknikerudvalg, 1973-1974. J.nr. 122.3.e. og Læg: Trafikplan 1980, Hovedstadsrådet, 1981, J.nr. 123.3b-d, 1953-1981, Emneordnede sager: Vejdirektoratet I-II, 1967-1985, Sekretariatet for Teknisk Direktorat [Frederiksberg Stadsarkiv, A 1202]. J.nr. 121 I, 1982 og læg: Trafikplan 1980, Hovedstadsrådet, 1981, s, 10 og 13-19. [Frederiksberg Stadsarkiv A 10]. Regionsplan 1989, Hovedstadsrådet, opslag 2.7, Emneordnede sager: Hovedstadsrådet XII, 1989 Sekretariatet [Frederiksberg Stadsarkiv, A 10]

58 Trafikrådet, 1973-1974, J.nr. 123.3.b-d, 1953-1981, Sekretariatet for Teknisk Direktorat [Frederiksberg Stadsarkiv , A 1202]. J.nr. 121 V, 1972-1976, J.nr. 121 IV, 1976-1977, J.nr. 121 III, 1977-1978, J.nr. II, 1978, [Særlig række], J.nr. 121.1. II, 1974-1976, J.nr, 121.1. I, 1976-1979, Sekretariatet, [Frederiksberg Stadsarkiv, A 10].

${ }_{59}$ Kollektiv Trafikplan 1989, Hovedstadsrådet, 1989, s., 14-17, J.nr. 89-11332-2/I, 1988-1990, Sekretariatet, [Frederiksberg Stadsarkiv, A 10].

60 J.nr. 121 V, 1972-1976, J.nr. 121 IV, 1976-1977, J.nr. II, 1978, [Særlig række], J.nr. 121 XV, 1979, J.nr. 121 XIV, 1979, J.nr. XII, 1980, J.nr. VII, 1981, J.nr. 121 IV, 1981, , række], J.nr. 121 XV, 1979, J.nr. 121 XIV, 1979 , J.nr. XIII, 1980, J.nr. XI, 1980, J.nr. VI, 1981,Sekretariatet, , J.nr. 82-11331-I/II, 1982, 82-11331-I/III, 1983, J.nr. 8211331 I/X, 1985, Sekretariatet [Frederiksberg Stadsarkiv, A 10]. Statistisk Årbog for København, Frederiksberg m.m., 1990, s. 369. 
${ }^{61}$ Regional Varmeplan 1988, Hovedstadsrådet 1988, Emneordnede sager: Hovedstadsrådet X 1988. Regionsplan 1989, Hovedstadsrådet, opslag 4.4, Emneordnede sager: Hovedstadsrådet XII 1989. Delplan for udbygning med decentrale kraftvarmeværker i hovedstadsregionen, Hovedstadsrådet 1988, s. 10-31, 1988, Emneordnede sager: Hovedstadsrådet X 1988, Sekretariatet [Frederiksberg Stadsarkiv A 10].

62].nr. 121 V, 1972-1976, J.nr. 121 IV, 1976-1977, J.nr. 121 III, 1977-1978, J.nr. II, 1978, [Særlig række], J.nr. 121 XV, 1979, J.nr. 121 XIV, 1979, J.nr. XIII, 1980, J.nr. XI, 1980, J.nr. VI, 1981, J.nr. 82-11331-I/XV, 1983, 82-11331I/III, 1983, Sekretariatet, , J.nr. 121 II, 1982, , J.nr. 82-11331-I/II, 1983, J.nr. 82-11331-I/IX, 1984-1985, J.nr. 82-11331 I/XVIII, 1984-1990, J.nr. 82-11331 I/XVIII, 1984-1990, .nr. 82-11331 I/X, 1985, J.nr. 82-11331 I/XI, 1985, J.nr. 84-11331 I, 1984, Emneordnede sager: Hovedstadsrådet IV, 1987, V 1987 [Frederiksberg Stadsarkiv, A 10]Sekretariatet [Frederiksberg Stadsarkiv, A 10]. Statistisk Årbog for København, Frederiksberg m.m,. 1978 , s. 112 og 1990, s. 370. Joan Friis-Nielsen og Palle Jørgensen: Kloakering og vandrensning i Lyngby-Taarbæk gennem 100 år, Lyngbybogen 2003, s.102-106. Hovedstadsområdet. Befolkning. Opgaver. Økonomi. Hovedstadsreformudvalgets sekretariat, 1970, s. 86. J.nr. 121 V, 1972-1976, Sekretariatet [Frederiksberg Stadsarkiv, A 10]. J.nr. 108.13, 19611976, J. nr. 108.14, 1973-1982Sekretariatet for Teknisk Direktorat [Frederiksberg Stadsarkiv A 1202]. Statistisk Årbog for Hovedstadsregionen, Hovedstadsrådet, 1978, s. 141, 1982, s. 140, 1986, s. 152 og 1989, s. 151.

63 Redegørelse for lokalisering af lossepladser i hovedstadsregionen, Hovedstadsrådet, 1987, s. 9-21, Emneordnede sager: Hovedstadsrådet, III, 1987. Affaldsredegørelse for hovedstadsregionen 1988, Hovedstadsrådet 1988, s. 37-99, Emneordnede sager: Hovedstadsrådet VIV, 1989. Regionsplan 1989, Hovedstadsrådet, opslag 5.1-5.4 og 5.6, Emneordnede sager: Hovedstadsrådet XII, 1989 Sekretariatet [Frederiksberg Stadsarkiv, A 10].

64 J.P. Trap: Danmark, 5. udg. bd. III, 3, s. 1960, s. 1031-1032 og 1088. J.P- Trap: Danmark, 5. udg., bd. III, 1953, s. 45, 74, 83 og 92. https://www.nordsjaellandshospital.dk/om-hospitalet/organisation/historisk-

tilbageblik/Sider/Hilleroed.aspxhttps://www.nordsjaellandshospital.dk/om-hospitalet/organisation/historisktilbageblik/Sider/Helsingoer.aspxhttps://www.nordsjaellandshospital.dk/om-hospitalet/organisation/historisktilbageblik/Sider/Frederikssund.aspxhttps://www.nordsjaellandshospital.dk/om-hospitalet/organisation/historisktilbageblik/Sider/Frederiksvaerk.aspxhttps://www.nordsjaellandshospital.dk/om-hospitalet/organisation/historisktilbageblik/Sider/Hoersholm-Usseroed.aspxhttps://www.nordsjaellandshospital.dk/omhospitalet/organisation/historisk-tilbageblik/Sider/Esboenderup.aspxhttp://www.cfmoller.com/p/koege-sygehussygehus-oest-rask-i58.html

${ }_{65}^{65}$ Hovedstadsområdet. Befolkning. Opgaver. Økonomi. Hovedstadsreformudvalgets sekretariat, 1970, s. 111-116 og 274-287.

66 J.nr. FH 47 pk, 1970-1973, Hospitalsvæsenet [Frederiksberg Hospital, A 300]. J.nr. 121 IV, 1981, Sekretariatet [Frederiksberg Stadsarkiv, A 10]. https://www.nordsjaellandshospital.dk/om-hospitalet/organisation/historisktilbageblik/Sider/Hilleroed.aspxhttps://www.nordsjaellandshospital.dk/om-hospitalet/organisation/historisktilbageblik/Sider/Helsingoer.aspxhttps://www.nordsjaellandshospital.dk/om-hospitalet/organisation/historisktilbageblik/Sider/Frederikssund.aspxhttps://www.nordsjaellandshospital.dk/om-hospitalet/organisation/historisktilbageblik/Sider/Frederiksvaerk.aspxhttps://www.nordsjaellandshospital.dk/om-hospitalet/organisation/historisktilbageblik/Sider/Hoersholm-Usseroed.aspxhttps://www.nordsjaellandshospital.dk/omhospitalet/organisation/historisk-tilbageblik/Sider/Esboenderup.aspxhttp://www.cfmoller.com/p/koege-sygehussygehus-oest-rask-i58.html 